\author{
Universidade de São Paulo \\ FFCLRP - DEPARTAMENTO DE FÍSICA \\ Pós-GraduaÇÃo em Física aplicada À Medicina e Biologia
}

\title{
Investigação de modelos comportamentais de ratos por meio de algoritmos genéticos
}

\author{
Ariadne de Andrade Costa
}

Tese de doutorado apresentada à Faculdade de Filosofia, Ciências e Letras de Ribeirão Preto da Universidade de São Paulo, como parte das exigências para a obtenção do título de Doutor em Ciências. Área: Física aplicada à Medicina e Biologia.

Ribeirão Preto - SP

2015 


\section{ARIADNE DE ANDRADE COSTA}

\section{Investigação de modelos comportamentais de ratos por meio de algoritmos genéticos}

\section{VERSÃO CORRIGIDA}

Tese de doutorado apresentada à Faculdade de Filosofia, Ciências e Letras de Ribeirão Preto da Universidade de São Paulo, como parte das exigências para a obtenção do título de Doutor em Ciências. Área: Física aplicada à Medicina e Biologia.

Área de Concentração:

Física aplicada à Medicina e Biologia.

Orientador:

Prof. Dr. Renato Tinós.

Ribeirão Preto - SP 
Autorizo a reprodução e divulgação total ou parcial deste trabalho, por qualquer meio convencional ou eletrônico, para fins de estudo e pesquisa, desde que citada a fonte.

\section{FICHA CATALOGRÁFICA}

Costa, Ariadne de Andrade.

Investigação de modelos comportamentais de ratos por meio de algoritmos genéticos/ Ariadne de Andrade Costa; orientador Prof. Dr. Renato Tinós. Ribeirão Preto, 2015. 102p.

Tese de doutorado (Doutorado - Programa de Pós-Graduação em Física aplicada à Medicina e Biologia) - Faculdade de Filosofia, Ciências e Letras de Ribeirão Preto da Universidade de São Paulo.

1. algoritmo genético 2. labirinto em cruz elevado 3. rato 4. modelo comportamental 5. rede neural artifical 

Nome: Costa, Ariadne de Andrade

Tíitulo: Investigação de modelos comportamentais de ratos por meio de algoritmos genéticos

Tese de doutorado apresentada à Faculdade de Filosofia, Ciências e Letras de Ribeirão Preto da Universidade de São Paulo, como parte das exigências para a obtenção do título de Doutor em Ciências.

Aprovado em:

\section{Banca Examinadora}

Prof. Dr. :

Instituição:

Julgamento:

Assinatura:

Prof. Dr. :

Instituição:

Julgamento:

Assinatura:

Prof. Dr. :

Instituição:

Julgamento:

Assinatura:

Prof. Dr. :

Instituição:

Julgamento:

Assinatura:

Prof. Dr. :

Instituição:

Julgamento:

Assinatura: 


\section{Agradecimentos}

Agradeço primeiramente a meu orientador, Prof. Tinós, por todos os ensinamentos, a ajuda e a confiança. Foi muito bom trabalhar com você. Espero que o doutorado seja o início de várias colaborações científicas futuras.

Agradeço à CAPES pelo suporte financeiro.

Muito obrigada, Julian Tejada, Andrea M. G. Becerra, Ana Cristina M. Costa, Javier Leonardo, R. Rodriguez e Prof. Silvio Morato, por nos fornecerem os dados de experimentos com ratos reais!

Agradeço aos professores que participaram das minhas bancas de qualificação e defesa da tese pela presença e pelas críticas e sugestões.

Sou grata a todos os professores e funcionários da Filô. Obrigada, Júlio e pessoal da informática! Muito obrigada a todos do Valter! Também agradeço fortemente à Nilza e ao Ricardo, sempre eficientes e dispostos a ajudar.

Obrigada aos colegas da faculdade, principalmente à Denise, muito querida, com quem tenho, há anos, partilhado uma trajetória acadêmica em comum, e à Lariza, grande colega de laboratório.

Obrigada, Sandro, pela busca ao Pablito, que infelizmente ainda não foi encontrado. No mesmo sentido, agradeço ao Lucas. Agradeço também aos demais membros da família: Dna. Guiomar, Sr. Jair, Dna. Dagmar e Oliver pelo carinho ao longo de todos esses anos.

Agradeço com muito carinho às minhas fofuras: Cindi Picotó, Elvis e Babi. Essas gracinhas são tudo para mim. É claro que não poderia deixar de mencionar o Goobão e a Cezinha!!!

Agradeço à minha família o apoio. 


\section{Resumo}

COSTA, Ariadne de Andrade Investigação de modelos comportamentais de ratos por meio de algoritmos genéticos. 2015. 102 p. Tese de doutorado (Doutorado - Programa de Pós-Graduação em Física aplicada à Medicina e Biologia) - Faculdade de Filosofia, Ciências e Letras de Ribeirão Preto da Universidade de São Paulo. 2015.

O labirinto em cruz elevado é um dos aparatos experimentais mais utilizados em avaliações neurobiológicas de ansiedade e defesa de ratos e camundongos. Estudamos aqui o uso de redes neurais artificiais otimizadas por algoritmos genéticos para investigar o comportamento de ratos nesse labirinto. Ao contrário dos demais modelos já propostos, a construção da trajetória do agente virtual independe de dados experimentais conhecidos a priori. Mostramos que, ao utilizar um agente desenvolvido a partir da otimização de uma função de avaliação inspirada no conflito de medo e ansiedade, o modelo pode simular inclusive o efeito causado pela introdução de drogas ansiolíticas e ansiogênicas em ratos (clordiazepóxido $5 \mathrm{mg} / \mathrm{kg}$ e semicarbazida 20, 40 e $80 \mathrm{mg} / \mathrm{kg}$ ). Os resultados das simulações do agente virtual estão de acordo com dados experimentais, revelando que a exploração de braços abertos é reduzida em relação a dos braços fechados, especialmente sob inserção de drogas ansiogênicas, que intensificam o medo do animal. Drogas ansiolíticas, ao contrário, estimulam a exploração. Para finalizar, foi realizada uma investigação aprofundada das trajetórias e redes neurais artificiais dos melhores ratos controle virtuais (que simulam ratos sem efeito de drogas). Conforme sugerem os resultados, a função de avaliação proposta pode conter as características mais relevantes envolvidas no comportamento do rato no labirinto em cruz elevado. 
Palavras-chave: 1. algoritmo genético 2. labirinto em cruz elevado 3. rato 4. modelo comportamental 5. rede neural artifical 


\section{Abstract}

COSTA, Ariadne de Andrade Investigation of rat's behavioral models by genetic algorithms. 2015. 102 p. Thesis (Ph.D. - Postgraduate program in Physics applied to Medicine and Biology) - University of São Paulo Faculty of Philosophy, Sciences and Letters. 2015.

The elevated plus-maze is one of the most used experimental apparatus for neurobiological evaluations of anxiety and defense of rats and mice. We investigate here the use of artificial neural networks otimized by genetic algorithms to investigate the behavior of rats in this maze. Unlike other proposed models, the development of the virtual agent's trajectory is independent of prior known experimental data. We show that, when using a agent developed from the optimization of a function inspired by the anxiety and fear conflict, the model can even simulate the effect caused by the introduction of anxiolytic and axiogenic drugs in rats (chlordiazepoxide 5 $\mathrm{mg} / \mathrm{kg}$ and semicarbazide 20, 40 and $80 \mathrm{mg} / \mathrm{kg}$ ). The results of simulations of the virtual agent agree with experimental data, in which the exploration of open arms is reduced compared to the exploration of enclosed arms, especially under effects of anxiogenic drugs, which enhance the animal fear. Anxiolytic drugs, on the other hand, stimulate exploration. Finally, a detailed investigation of trajectories and artificial neural networks of the best virtual control rats (that simulate rats without drugs) was performed. As the results suggest, the proposed fitness function may contain the most relevant features involved in the behavior of rats in the elevated plus-maze.

Key-words: 1. genetic algorithm 2. elevated plus maze 3. rat 4. behavioral model 5. artificial neural network 


\section{Lista de Figuras}

2.1 Rato Wistar no labirinto em cruz elevado do Laboratório de Comportamento Exploratório da Faculdade de Filosofia, Ciências e Letras de Ribeirão Preto, coordenado pelo Prof. Dr. Silvio Morato. . 6

3.1 Diagrama de uma rede neural artificial multicamada sem recorrência, com duas camadas intermediárias. As unidades sensoriais são representadas pelos quadrados, enquanto os neurônios são representados pelas elipses. . . . . . . . . . . . . . . . . . . . . 12

3.2 Diagrama de duas redes recorrentes diferentes. . . . . . . . . . . . . 13

3.3 Algoritmo genético típico [47]. . . . . . . . . . . . . . . . . . 20

3.4 Indivíduos de uma população e a sua correspondente roleta de seleção. 23

3.5 Esquema gráfico da recombinação de um ponto. $\mathrm{O}$ ponto de recombinação escolhido foi a posição quatro do cromossomo. Figura adaptada de [69]. . . . . . . . . . . . . . . . . . . . . . . . . . . . . . . . . . . 24

3.6 Esquema gráfico da recombinação de dois pontos, com os pontos de recombinação dois e seis. Figura adaptada de [69] . . . . . . . . . . 25

3.7 Esquema gráfico do cruzamento uniforme. Figura adaptada de [69]. . 25

3.8 Esquema gráfico de ocorrência de mutação. Na representação binária, a mutação ocorre por inversão do bit. Figura adaptada de [69]. . . . . 26

3.9 Representação gráfica de um espaço de busca grande e multimodal, denotando seu o ótimo global e um ótimo local. Figura adaptada

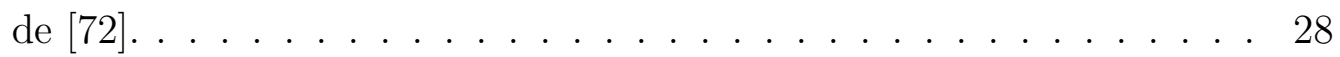


4.1 (a) O labirinto completo exibido na figura constitui o espaço de navegação de ratos reais e virtuais durante o experimento; (b) os braços fechados são considerados indistinguíveis entre si para análise do comportamento do rato, assim como os braços abertos; (c) o labirinto reduzido, composto apenas por linhas pretas sólidas na figura, é usado para análise dos resultados. As posições 1-5 representam os braços abertos do labirinto. O braço com a linha em negrito representa o braço fechado do LCE reduzido (posições 7-11). A posição 6 corresponde ao centro. . . . . . . . . . . . . . . . . . 32

4.2 Esquema representativo da rede neural que define o rato virtual. A rede é composta por 10 elementos de entrada (6 sensores e 4 elementos realimentados pela camada intermediária), 4 neurônios recorrentes e 4 neurônios de saída. . . . . . . . . . . . . . . . . . . . . . 34

4.3 Esquema das etapas do algoritmo genético. Os resultados são obtidos com populações de 1.000 indivíduos evoluídos durante 15.000 gerações. Os resultados são obtidos para 30 execuções do AG. . . . . 36

4.4 Função de avaliação e valores de seus parâmetros utilizados no modelo. 37

5.1 Média e erro padrão (a) do tempo de permanência nos braços abertos e fechados, (b) da quantidade de movimentos feitos em cada tipo de braço, (c) do número de entradas e (d) chegadas às extremidades em cada tipo de braço para ratos reais e virtuais em testes de cinco minutos no LCE. Para otimização dos ratos virtuais, foi-se utilizado $\beta=3,2$. O símbolo * indica quando é possível afirmar que os resultados dos ratos reais e virtuais são de populações diferentes de acordo com o teste Mann-Whitney com nível de significância 0,05. . .

5.2 Matriz Markoviana de ratos controle (a) reais, (b) virtuais com rede fixa e (c) virtuais com rede evolutiva no LCE. . . . . . . . . . . . . . 44

5.3 Vetor $\pi$ para ratos controle (a) reais, b) virtuais com rede fixa e (c) virtuais com rede evolutiva. As posições 1-5 correspondem aos braços abertos do labirinto, enquanto 7-11 correspondem aos braços fechados, e a posição 6 ao centro. 
5.4 Média e erro padrão (a) do tempo de permanência nos braços abertos e fechados, (b) da quantidade de movimentos feitos em cada tipo de braço, (c) do número de entradas e (d) chegadas às extremidades em cada tipo de braço para ratos reais e virtuais sob efeito de semicarbazida $20 \mathrm{~m} / \mathrm{kg}$. O único parâmetro modificado em relação às simulações do rato controle é o $\beta$. Nestas simulações, $\beta=6,3$. $\mathrm{O}$ símbolo * indica que os resultados dos ratos reais e virtuais são de populações diferentes de acordo com o teste Mann-Whitney com nível de significância 0,05 .

5.5 Matriz Markoviana de ratos (a) reais, (b) virtuais com rede fixa e (c) virtuais com rede evolutiva sob efeito de droga semicarbazida na concentração de $20 \mathrm{mg} / \mathrm{kg}$ no LCE. . . . . . . . . . . . . . . . . . . . 48

5.6 Vetor $\pi$ para ratos (a) reais reais sob efeito de semicarbazida $20 \mathrm{mg} / \mathrm{kg}$ e (b) virtuais com o parâmetro $\beta=2,2$. As posições 1-5 são os braços abertos do labirinto, 6-11 correspondem aos braços fechados e a posição 6, ao centro.

5.7 Média e erro padrão (a) do tempo de permanência nos braços abertos e fechados, (b) da quantidade de movimentos feitos em cada tipo de braço, (c) do número de entradas e (d) chegadas às extremidades em cada tipo de braço para ratos reais e virtuais sob efeito de clordiazepóxido $5 \mathrm{mg} / \mathrm{kg}$ em testes de cinco minutos no LCE. Nas simulações, $\beta=2,2$. O símbolo $*$ indica que os resultados dos ratos reais e virtuais são de populações diferentes de acordo com o teste Mann-Whitney com nível de significância 0,05 . . . . . . . . . . . . 50

5.8 Matriz Markoviana de ratos (a) reais, (b) virtuais com rede fixa e (c) virtuais com rede evolutiva sob efeito de droga ansiolítica clordiazepóxido na concentração de $5 \mathrm{mg} / \mathrm{kg}$ no LCE, . . . . . . . . . 51

5.9 Vetor $\pi$ para ratos (a) reais sob efeito de clordiazepóxido $5 \mathrm{mg} / \mathrm{kg}$ e (b) virtuais com o parâmetro $\beta=6,0$. As posições 1-5 são os braços abertos do labirinto, 6-11 correspondem aos braços fechados e a posição 6 ao centro. . . . . . . . . . . . . . . . . . 52 
5.10 Dependência do tempo gasto nos braços (a) fechados e (b) abertos, e a frequência de entradas nos braços (c) fechados e (d) abertos dos ratos virtuais devido à veriação de $\beta$. Os "insets' mostram o valor das mesmas variáveis para ratos reais controles (CTRL) e sob efeito de droga semicarbazida (SCZ) na concentração de 20, 40 e $80 \mathrm{mg} / \mathrm{kg}$, e clordiazepóxido (CDP) de $5 \mathrm{mg} / \mathrm{kg}$. . . . . . . . . . . . . . . . 53

6.1 Evolução da média de sensores e neurônios intermediários de toda a população de 30 execuções ao longo das 15.000 gerações dos ratos controle virtuais com redes evolutivas. . . . . . . . . . . . . 57

6.2 (a) Modelo do labirinto em cruz elevado implícito nos gráficos das trajetórias dos ratos reais e virtuais exibidos neste capítulo. As posições 1 a 5 e -1 a -5 correspondem aos braços fechados opostos. As posições 6 a 10 e -6 a -10 representam os braços abertos. 0 é a posição central. (b) Esquema das orientações seguido pelo rato virtual no labirinto. . . . . . . . . . . . . . . . . . . . 63

6.3 (a) Gráfico da trajetória desempenhada por um rato controle virtual que permaneceu parado no labirinto após período transiente de 30 passos de tempo da simulação computacional; (b) ilustração do labirinto em cruz elevado com a mesma trajetória do rato virtual. O esquema auxilia na compreensão do trajeto seguido por este agente. Curtas pausas não foram evidenciadas no esquema. . . . . . . . . . 63

6.4 Diferentes trajetórias percorridas pelos ratos controle virtuais, exemplificando os comportamentos: (a) girando no lugar, (b) periódico, (c) estratégia se repete, (d) combinação de estratégias, (e) variável. . . . . . . . . . . . . . . . . . . . . . . . . . . . . 64

6.5 Diferentes trajetórias percorridas pelos ratos controle reais, exemplificando os comportamentos: (a) parado, (b) e (c) estratégia se repete, (d) variável. 
6.6 Trajetória desempenhada por um rato controle virtual que permaneceu parado no labirinto após 5 passos de tempo; (b) ilustração do labirinto em cruz elevado com a trajetória e uma representação dos valores de entrada da rede neural artificial em escala de cinza nos 5 primeiros passos de tempo. As entradas E1 e E2 são recorrências de neurônios intermediários e E3 e E4 são os sensores de curta distância à esquerda e à frente. Na escala de cores, preto corresponde ao valor 1,0 de entrada e branco, ao valor 0,0 ; valores intermediários equivalem a tons de cinza. . . . . . . . . . . . . . . . . . .

6.7 Rede neural artificial correspondente ao rato virtual cuja trajetória consta na Figura 6.6. A rede é composta por quatro elementos de entrada (E1, E2, E3, E4), sendo duas recorrências (E1 e E2) e dois sensores (E3 e E4), dois neurônios intermediários (N1, N2) e quatro neurônios de saída (S1 - seguir em frente (F), S2 - virar à esquerda (E), S3 - virar à direita (D) e S4 - ficar parado (P)). Os pesos sinápticos são mencionados nas arestas do grafo. O bias de cada neurônio também é exibido na figura. . . . . . . . . . . . . . . . . . . . . . . 70

6.8 Ativação dos neurônios intermediários durante a trajetória exibida na Figura 6.6. . . . . . . . . . . . . . . . . . 71

6.9 (a) Ativação dos neurônios de saída durante a trajetória exibida na Figura 6.6; (b) ativação de todos os neurônios de saída dos instantes $t=0$ a $t=45$ em um único gráfico, facilitando a comparação de seus valores. . . . . . . . . . . . . . . . . . . . . 72

6.10 Trajetória de um rato virtual com dois tipos de comportamentos periódicos distintos. . . . . . . . . . . . . . . . . . . 73 
6.11 Rede neural artificial correspondente ao rato virtual cuja trajetória consta na Figura 6.6. A rede é composta por quatro elementos de entrada, sendo quatro recorrências de neurônios intermediários(E1, E2, E3, E4) e dois sensores (um à esquerda de curta distância, E5, e outro frontal de longa distância, E6), quatro neurônios recorrentes (N1, N2, N3, N4) e quatro neurônios de saída (S1 - seguir em frente (F), S2 - virar à esquerda (E), S3 - virar à direita (D) e S4 - ficar parado $(\mathrm{P})$ ). Os pesos sinápticos das conexões da rede e os bias dos neurônios são apresentados na Tabela 6.5 . . . . . . . . . . . . . . . . 74

6.12 Ativação dos neurônios intermediários durante a trajetória exibida na Figura 6.10 . . . . . . . . . . . . . . . . 76

6.13 (a) Ativação dos neurônios de saída durante a trajetória exibida na Figura 6.6; (b) ativação de todos os neurônios de saída dos instantes $t=0$ a $t=45$ em um único gráfico, facilitando a comparação de seus valores. . . . . . . . . . . . . . . . . . . . . . 77

6.14 Trajetória desempenhada pelo rato virtual nos durante as iterações $t=0$ a $t=18$; (b) ilustração do labirinto em cruz elevado com a trajetória e uma representação dos valores de entrada da rede neural artificial em escala de cinza nesses passos de tempo (as setas verdes mostram a orientação do rato virtual); ativação dos neurônios (c) intermediários e (d) de saída correspondentes. . . . . . . . . . . . . 79

6.15 Trajetória desempenhada pelo rato virtual durante as iterações $t=24$ a $t=64$; (b) ilustração do labirinto em cruz elevado com a trajetória e uma representação dos valores de entrada da rede neural artificial em escala de cinza nesses passos de tempo; ativação dos neurônios (c) intermediários e (d) de saída correspondentes. . . . . . . . . . . . 80

6.16 Trajetória desempenhada pelo rato virtual durante as iterações $t=$ 104 a $t=116$; (b) ilustração do LCE com a trajetória e uma representação dos valores de entrada da rede neural artificial em escala de cinza nesses passos de tempo; ativação dos neurônios (c) intermediários e (d) de saída correspondentes. . . . . . . . . . . . . 81 
6.17 Ativações dos neurônios (a) intermediários e (b) de saída nas iterações $t=24$ a $t=114$. Em amarelo há um destaque para o período que compreende cada um dos ciclos comportamentais existente na região entre $t=24$ e $t=104$. A linha tracejada rosa ressalta o momento da transição comportamental do rato virtual $(t=104)$. . . . . . . . . . 83

A.1 Esquema ilustrativo que retrata um neurônio típico. Numa extremidade se encontra a árvore dendrítica, no centro está localizado o soma e na outra extremidade o axônio. Figura adaptada de [76] . . . 97

A.2 Foto de uma rede neuronal típica de ratos reais saudáveis. Imagem adaptada de $[82] . \ldots \ldots \ldots 9$ 


\section{Lista de Tabelas}

2.1 Situações possíveis para o rato a cada instante no Modelo de Inércia de Giddings e Archibald [18] . . . . . . . . . . . . . . . . . . . 8

4.1 Entradas sensoriais do rato virtual. A angulação de $0^{\circ}$ é considerada como a frente do rato. A direção é usada para representar as posições dos sensores de paredes no agente. Os sensores de curto alcance detectam paredes apenas na posição atual do rato virtual, enquanto os de longo alcance abrangem duas posições além de sua posição atual. 33

5.1 Média e erro padrão (EP) dos parâmetros das curvas de ajustes exponenciais contidas na Figura 5.10. Na equação dos ratos reais, $x$ corresponde à dosagem da droga, enquanto que $x=\beta$ para os ratos virtuais. . . . . . . . . . . . . . . . . . . 54

6.1 Quantidade e porcentagem dos melhores ratos virtuais com 1, 2, 3, 4, 5 ou 6 sensores na arquitetura de suas RNAs. . . . . . . . . . 58

6.2 Combinações dos sensores dos melhores agentes (ratos) virtuais das 30 execuções do AG. Na tabela, "L" significa "Longa distância" e "C", "Curta distância". A quantidade e a porcentagem de ratos com cada combinação de sensores são apresentadas, assim como o número de neurônios intermediários de cada um dos ratos virtuais. Os símbolos ** indicam os três ratos virtuais com maior fitness calculado. . . . . . 60

6.3 Quantidade e porcentagem de neurônios na camada oculta dos 30 ratos virtuais (cada um correspondendo ao melhor rato de uma execução do AG) . . . . . . . . . . . . . . . . . . . . . . . . . . . . . . 61 
6.4 Quantidade e porcentagem de ratos virtuais a desempenhar cada tipo de comportamento geral observado no LCE virtual. . . . . . . . . . . 66

6.5 Pesos sinápticos das conexões entre (a) elementos de entrada e neurônios intermediários, e (b) neurônios intermediários e de saída, referentes à RNA apresentada na Figura 6.11. . . . . . . . . . . . . . 75 


\section{Lista de abreviaturas}

AG algoritmo genético

ADN ácido desoxirribonucleico

ARN ácido ribonucleico

BA braço aberto do labirinto em cruz elevado reduzido, correspon-

dente ao par de braços abertos do labirinto virtual

BF braço fechado do labirinto em cruz elevado reduzido, correspon-

dente ao par de braços fechados do labirinto virtual

C curta distância

CDP clordiazepóxido

DC direita - curta distância

DL direita - longa distância

EC esquerda - curta distância

EL esquerda - longa distância

EP erro padrão

FC frente - curta distância

FL frente - longa distância

L longa distância 
LCE labirinto em cruz elevado

MLP perceptron multicamadas

RNA rede neural artificial

SCZ semicarbazida 


\section{Lista de símbolos}

E1 entrada número um

E2 entrada número dois

E3 entrada número três

E4 entrada número quatro

E5 entrada número cinco

E6 entrada número seis

$f(\mathbf{x})$ função de avaliação

n número máximo de passos de tempo

N1 neurônio intermediário número um

N2 neurônio intermediário número dois

N3 neurônio intermediário número três

N4 neurônio intermediário número quatro

$p_{i j} \quad$ elementos da matriz $P$

$p_{\max }$ número total de posições do LCE

$p_{t} \quad$ posição do LCE ocupada no passo de tempo $t$, sendo $p_{t}=1, \ldots, p_{\max }$

P matriz estocástica Markoviana 
$r\left(\mathbf{x}, p_{t}\right)$ possível recompensa do rato virtual, dado pela solução $\mathbf{x}$, conforme sua posição atual $p_{t}$

$s\left(\mathbf{x}, p_{t}\right)$ possível punição do rato conforme o tipo de braço (ou posição central) no qual se encontra

S1 saída número um

S2 saída número um

S3 saída número um

S4 saída número um

$\mathbf{x} \quad$ cromossomo do indivíduo avaliado (solução do AG)

z número aleatório com distribuição uniforme no intervalo $[0,1]$

$\alpha_{a} \quad$ probabilidade do rato virtual sofrer punição nos braços abertos

$\alpha_{c} \quad$ probabilidade do rato virtual sofrer punição no centro

$\alpha_{f} \quad$ probabilidade do rato virtual sofrer punição nos braços fechados

$\alpha\left(p_{t}\right) \quad$ probabilidade do rato virtual sofrer punição na posição atual $p_{t}$

$\beta \quad$ peso da punição do rato

$\gamma \quad$ parâmetro relacionado à "memória" do agente

$\pi \quad$ vetor de probabilidades de encontrar o rato em cada posição do LCE reduzido no estado estacionário 


\section{Sumário}

Lista de Figuras $\quad$ ix

Lista de Tabelas $\quad$ xvi

$\begin{array}{ll}\text { Lista de abreviaturas } & \text { xviii }\end{array}$

Lista de simbolos $\quad \mathrm{xx}$

1 Introdução 1

1.1 Hipótese . . . . . . . . . . . . . . . . . . . . . . . . 3

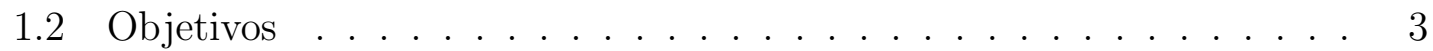

1.2.1 Objetivo geral . . . . . . . . . . . . . . . . 3

1.2 .2 Objetivos específicos . . . . . . . . . . . . . . 3

1.3 Estrutura da tese . . . . . . . . . . . . . . . . . 4

2 Modelos comportamentais para roedores no labirinto em cruz elevado 5

$\begin{array}{lll}3 & \text { Redes neurais artificiais e algoritmos genéticos } & 11\end{array}$

3.1 Redes neurais artificiais . . . . . . . . . . . . . . . . . . 11

3.1.1 Arquitetura de RNAs . . . . . . . . . . . . . . . . . . 12

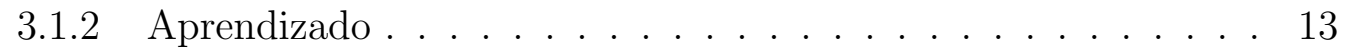

3.1.2.1 Aprendizado supervisionado . . . . . . . . . . . . 14

3.1.2.2 Aprendizado não supervisionado . . . . . . . . . . . 14

3.1.2.3 Aprendizado por avaliação da qualidade das soluções 14

3.1 .3 Tipos de rede . . . . . . . . . . . . . . . . 15

3.2 Algoritmos genéticos . . . . . . . . . . . . . . . . 16 
xxiii

3.2.1 Breve história da computação evolutiva . . . . . . . . . . . 17

3.2 .2 Elementos dos AGs . . . . . . . . . . . . . . . . . . . 19

3.2.2.1 Representação . . . . . . . . . . . . . . . . 20

3.2.2.2 Seleção . . . . . . . . . . . . . . . . . . . . . . . . 21

3.2.2.3 Função de aptidão . . . . . . . . . . . . . . . . . . 23

3.2.2.4 Recombinação . . . . . . . . . . . . . . . . 24

3.2.2.5 Mutação . . . . . . . . . . . . . . . . 25

3.2 .3 Parâmetros do AG . . . . . . . . . . . . . . 26

3.2.4 Quando funcionam os AGs . . . . . . . . . . . . . . . . 27

4 Métodos da pesquisa $\quad 29$

4.1 Experimentos com ratos reais . . . . . . . . . . . . . . . . . 29

4.2 LCE virtual . . . . . . . . . . . . . . . . . . . . . . . . . 31

4.3 Modelo computacional 1 - rede estática . . . . . . . . . . . . . . . . 32

4.3.1 Rede neural artificial . . . . . . . . . . . . . . . . 33

4.3.2 Algoritmo genético . . . . . . . . . . . . . . . . . 35

4.4 Modelo computacional 2 - rede evolutiva . . . . . . . . . . . . . 38

4.5 Análise dos resultados . . . . . . . . . . . . . . . . . . . . . 39

4.6 Análise das trajetórias e redes neurais artificiais . . . . . . . . . . . . 41

5 Resultados: parâmetro $\beta \quad 42$

6 Resultados: redes neurais artificiais e trajetórias no LCE 56

6.1 Arquiteturas das redes neurais artificiais . . . . . . . . . . 56

6.2 Trajetórias no LCE real e virtual _ . . . . . . . . . . . . . . . . 61

6.3 Estudo da ativação dos neurônios da RNA de ratos virtuais no LCE . 68

6.3.1 Exemplo 1...................... 68

6.3 .2 Exemplo $2 \ldots \ldots \ldots \ldots 73$

6.3.2.1 Parte 1: início . . . . . . . . . . 78

6.3.2.2 Parte 2: exploração de braços abertos . . . . . . . . 80

6.3.2.3 Parte 3: exploração do braço fechado . . . . . . . . . 81

6.3.2.4 Transições de comportamento . . . . . . . . . . . . . 82 
xxiv

7 Conclusão $\quad 85$

7.1 Perspectivas . . . . . . . . . . . . . . . 86

$\begin{array}{lr}\text { Referências Bibliográficas } & 88\end{array}$

$\begin{array}{ll}\text { A Sistemas nervosos biológicos } & 97\end{array}$

B A terminologia biológica no uso de algoritmos genéticos $\quad 100$ 


\section{Capítulo}

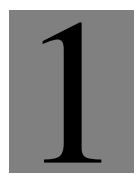

\section{Introdução}

No passado, a principal motivação humana à busca do conhecimento e da compreensão do comportamento dos animais era a própria sobrevivência. No entanto, a complexidade e a variedade presentes no reino animal vêm instigando a formulação de perguntas e hipóteses, tornando este tipo de estudo cada vez mais motivado pelo prazer que o entendimento nos traz. Contudo, é essencial ter em mente que qualquer afirmação científica não pode ser considerada uma verdade absoluta ou definitiva. Assim, comumente são construídas representações do mundo com o propósito de simplificar a realidade: os chamados modelos. A construção de um modelo se baseia em teorias, considerando observações e hipóteses sobre a estrutura do sistema em questão, permitindo sua representação com maior ou menor precisão, conforme o desejo, necessidade ou recursos do pesquisador.

Uma das simplificações frequentemente realizadas na análise do comportamento animal é assumir que as ações dos animais, como espécies, são ótimas ou subótimas. Segundo esta premissa, o comportamento atual do animal é resultante de um processo de otimização, geralmente envolvendo evolução natural e/ou aprendizado. Sendo assim, modelos de comportamento animal podem ser construídos e investigados com auxílio de técnicas de otimização, como, por exemplo, a computação evolutiva, inspirada no processo de evolução natural dos seres vivos. Devido às suas características, a computação evolutiva vem sendo utilizada em problemas dificilmente tratáveis analiticamente. Como exemplo das aplicações da computação evolutiva, pode-se citar o aprendizado de máquinas e o desenvolvimento de hardware [1]. 
A principal diferença entre a evolução natural e a evolução artificial é o modo como é calculada a aptidão de cada indivíduo. Na evolução natural, cada avanço evolutivo tem seu custo e é a seleção natural que indica se a vantagem adquirida compensa o seu preço. Quanto maior for o número de descendentes férteis deixados por um indivíduo, pode-se dizer que mais justificados são os custos das estratégias utilizadas em sua vida. Deste modo, a aptidão de um indivíduo é definida como seu sucesso reprodutivo, ou seja, o número de descentes vivos produzidos que atingem a idade reprodutiva. No entanto, na evolução artificial, a aptidão de um indivíduo é dada por uma função (comumente chamada de função objetivo ou de aptidão) que é definida pelo programador de acordo com o problema que deve ser resolvido.

No presente trabalho, aplicamos a computação evolutiva com intuito de reproduzir o comportamento médio de ratos no labirinto em cruz elevado (LCE), com inspiração no processo evolutivo, ou de aprendizado, através do qual o rato adquiriu seu comportamento. Com isso, buscamos também investigar as bases causais desse comportamento. Para tanto, propusemos uma função objetivo fundamentada no conflito do animal que envolve medo e curiosidade de explorar o novo ambiente [2], a qual utilizamos em dois diferentes modelos. Em um dos modelos, um algoritmo genético é usado para otimizar os pesos de uma rede neural artificial (RNA); no outro modelo, a arquitetura da rede também é otimizada. A RNA é o agente computacional, aqui chamado de rato virtual.

Uma das grandes utilidades dos modelos é capacidade de predizer fenômenos reais. Em nosso caso, a predição é de imensa valia, pois pode reduzir experimentos com ratos reais, o que implica em menos sofrimento e morte desses animais. Isto porque os experimentos no LCE geralmente são feitos com ratos que nunca passaram antes pelo labirinto, para garantir um maior interesse exploratório. Deste modo, especialmente quando alguma droga foi inserida no animal, ele costuma ser sacrificado após o experimento - exceto nos raros casos em que o animal poderá ser aproveitado em outro experimento (no LCE ou não). Além disso, nossos modelos correspondem a um arcabouço geral que pode ser facilmente adaptável para o teste de outros modelos de comportamento desenvolvidos na Psicobiologia. 


\section{$1.1 \quad$ Hipótese}

Nossa hipótese é de que uma rede neural otimizada utilizando-se uma função de avaliação baseada no conflito entre medo e exploração é suficiente para simular o comportamento médio de ratos reais no LCE.

\subsection{Objetivos}

\subsubsection{Objetivo geral}

O objetivo de nosso trabalho é investigar o comportamento de ratos no LCE a partir de modelos envolvendo redes neurais artificiais evoluídas por algoritmos genéticos, estudando o comportamento médio de ratos reais e virtuais, como também o papel dos neurônios das redes neurais artificiais e a quantidade de sensores e neurônios relevantes para ratos virtuais, para então inferir/verificar informações sobre ratos reais.

\subsubsection{Objetivos específicos}

Nosso objetivo geral divide-se em objetivos específicos:

- Propor uma função de avaliação para algoritmos genéticos inspirada no conflito de medo/curiosidade exploratória de ratos reais no labirinto em cruz elevado;

- Estudar modelos computacionais de ratos virtuais baseados em redes neurais artificais evoluídas por algoritmos genéticos para definir um bom modelo a ser explorado;

- Estudar e ajustar os parâmetros do modelo, comparando os resultados de variáveis que descrevem o comportamento exploratório médio do rato virtual com os resultados médios correspondentes de ratos reais;

- Desenvolver novo modelo computacional, evoluindo com o algoritmo genético não apenas os pesos da rede neural artificial, mas a arquitetura da rede (número de sensores e neurônios intermediários);

- Estudar e ajustar os parâmetros do novo modelo; 
- Comparar os dois modelos estudados;

- Investigar o papel da arquitetura e dos neurônios intermediários da rede neural artificial de ratos virtuais;

- Comparar os resultados com dados de ratos reais e inferir informações sobre a rede neuronal destes roedores.

\subsection{Estrutura da tese}

A fim de contextualizar nossa pesquisa e caracterizar melhor o problema em questão, no Capítulo 2 trazemos mais detalhes sobre o experimento com ratos no LCE, bem como uma revisão bibliográfica de modelos computacionais pertinentes à área. O Capítulo 3 contém uma breve introdução aos métodos computacionais usados e o Capítulo 4, os métodos específicos implementados na pesquisa. Já o Capítulo 5 reporta os resultados obtidos nas simulações de ratos sob diferentes condições farmacológicas. No Capítulo 6, estudamos as redes neurais artificiais que compõem os melhores ratos controles obtidos e suas respectivas trajetórias. Finalizamos no Capítulo 7, com as conclusões e perspectivas da pesquisa. 


\section{Capítulo}

\section{Modelos comportamentais para roedores no labirinto em cruz elevado}

O labirinto em cruz elevado é um aparato experimental bastante simples, usado como uma ferramenta geral de pesquisa para estudos neurobiológicos de ansiedade e defesa. Mais especificamente, é usualmente utilizado para mensurar reações comportamentais de ratos relacionadas à ansiedade [3]. O equipamento consiste de um labirinto em formato de cruz, com dois dos braços diametralmente opostos envoltos por paredes, chamados de braços fechados, e os outros dois braços sem paredes ao redor, chamados de braços abertos. O tamanho dos braços é igual, possuindo normalmente cerca de $50 \mathrm{~cm}$ de comprimento e $10 \mathrm{~cm}$ de largura cada um. A parede dos braços fechados costumam ter $30 \mathrm{~cm}$ de altura e o labirinto fica elevado a $50 \mathrm{~cm}$ do solo. Os quatro braços são conectados pela região central do labirinto.

São duas as grandes vantagens dos experimentos no LCE que tornam este labirinto tão popular. A primeira delas é que o uso do LCE é bastante simples, não sendo necessário treinar o animal antes dos testes. Pelo contrário, para a maioria dos experimentos, o ideal é justamente que o animal nunca tenha tido contato com o aparato. A segunda vantagem é que não é necessário privar o animal de nenhum recurso básico, como comida e água; é desejado que o animal esteja tranquilo ao ser colocado no labirinto. A Figura 2.1 mostra a foto de um rato durante um experimento no LCE.

Os experimentos no LCE derivam de estudos realizados por Montgomery, em 


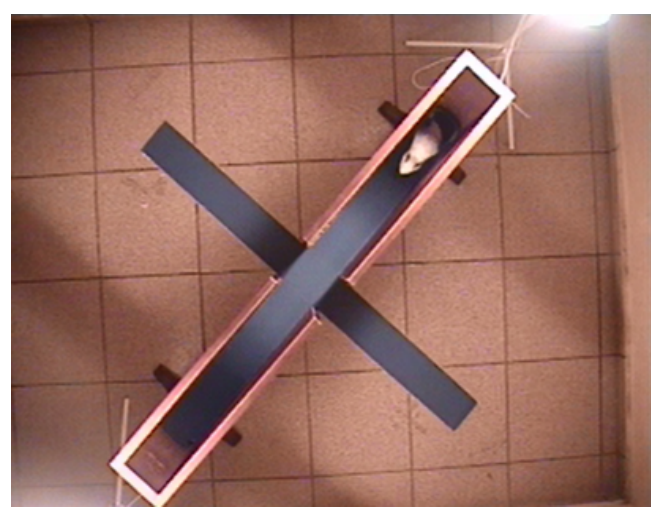

Figura 2.1: Rato Wistar no labirinto em cruz elevado do Laboratório de Comportamento Exploratório da Faculdade de Filosofia, Ciências e Letras de Ribeirão Preto, coordenado pelo Prof. Dr. Silvio Morato.

1955, sobre a relação de medo e ansiedade em ratos durante sua exposição a um novo ambiente [2], provocando-lhes sensações de medo e curiosidade simultaneamente. Estes sentimentos são interpretados como mecanismos adaptativos de defesa a estímulos perigosos e desconhecidos [4].

Em 1984, o aparato utilizado por Montogomery foi adaptado para o que é hoje, de fato, conhecido como LCE [5]. Os primeiros resultados para validar comportamental, fisiológica e farmacologicamente o LCE foram obtidos em 1985 [6], difundindo-se rapidamente por pesquisadores de áreas afins. Depois disto, muitos estudos foram propostos buscando compreender os mecanismos envolvidos no comportamento de ratos no LCE $[7,8]$. A maioria deles se baseia em resultados obtidos primeiramente por Montgomery [2], que mostram que ratos passam significantemente mais tempo nos braços fechados dos que nos braços abertos do labirinto, pois o medo da exposição prevalece sobre a curiosidade de explorar um novo ambiente.

São muitos os trabalhos estudando o comportamento de ratos no $\mathrm{LCE}^{1}$. Vários pesquisadores têm tentado compreender os mecanismos implícitos no comportamento desses roedores ao percorrer o labirinto. Por exemplo, resultados suerem que a altura do labirinto não é o que provoca a aversão pelos braços abertos: testes com diferentes alturas não apresentaram diferenças significantes [9]. Além disso, ratos submetidos ao LCE em condições de baixa luminosidade exploraram mais os braços abertos do que ratos submetidos ao mesmo experimento em plenas

\footnotetext{
${ }^{1}$ Uma busca na base de dados PubMed usando termo "elevated plus maze" como descritor retornou 5.719 artigos de diferentes áreas do conhecimento (busca feita em 23/08/2015).
} 
condições de visibilidade. Isso indica que a distinção visual da presença/ausência de paredes é importante para que o rato prefira os braços fechados em detrimento dos braços abertos do labirinto [10]. Outra pesquisa mostrou que, quando estímulos auditivos e olfativos são controlados, a aversão em ratos é desencadeada pela visão [11]. Mais que esses fatores, a idade [12, 13, 14] e o estado nutricional [15, 16, 17], por exemplo, também influenciam a aversão aos braços abertos.

Curiosamente, dentre todos os trabalhos publicados envolvendo ratos no LCE, apenas nove exploraram modelos computacionais, de acordo com o conhecimento da autora $[18,19,20,21,22,23,24,25,26]$ (dentre esses, quatro são artigos nossos publicados durante o doutorado). Todos estes modelos tentam simular o comportamento médio de ratos machos ingênuos (ou seja, que não estiveram antes no labirinto) explorando o LCE por cinco minutos. São feitas essas considerações já que, com frequência, após cinco minutos os ratos reduzem a taxa de exploração no labirinto, pois a habituação com o ambiente afeta seu interesse [2]; além disso é diferente o comportamento de machos e fêmeas [27, 12, 28, 29, 30]. Nos modelos mencionados, o espaço contido no LCE é discreto, com uma posição central e três $[18,20]$ ou cinco $[19,21,22,23,24,25,26]$ posições (quadrados) em cada braço. No modelo proposto por Salum, Morato e Roque-da-Silva em 2000 [19], são usadas redes neurais artificiais (RNAs) treinadas por aprendizado competitivo, sendo cada unidade da rede uma posição do labirinto. Os autores consideraram três parâmetros de entrada: necessidade de exploração, aversão a estímulos repulsivos e atividade motora espontânea (atividade basal do animal). Para demonstrar a generalidade do modelo, estudaram não apenas o LCE tradicional, mas também um labirinto completamente aberto e outro completamente fechado.

O segundo modelo computacional de ratos no LCE foi desenvolvido por J. Giddings e T. Archibald [18]. Eles seguiram a ideia de "inércia de movimento", segundo a qual o rato tende a continuar se movendo na mesma direção em que já está. Porém, a probabilidade de isso acontecer é diferente de acordo com a posição ocupada no LCE. Com isso, sete diferentes situações do agente são consideradas, como mostra a Tabela 2.1. Cada uma delas permite um diferente grupo de possíveis ações probabilísticas que definirá o comportamento do agente no passo de tempo seguinte. Estas probabilidades são parâmetros do modelo. Os resultados não 
envolveram apenas o tempo de permanência nos braços abertos e fechados, como também o número de entradas em cada um deles. Os valores obtidos são bem próximos dos valores médios de 34 experimentos com ratos reais conduzidos no laboratório da Profa. Dra. Lisa Kalynchuk's, na Universidade de Dalhousie.

\begin{tabular}{|c|c|}
\hline Região do LCE & Movimento \\
\hline \hline Braços abertos & $\begin{array}{c}\text { Movendo-se em direção à extremidade } \\
\text { Movendo-se em direção ao centro }\end{array}$ \\
\hline Braços fechados, não-adjacente ao centro & $\begin{array}{c}\text { Movendo-se em direção à extremidade } \\
\text { Movendo-se em direção ao centro }\end{array}$ \\
\hline Braços fechados, adjacente ao centro & $\begin{array}{c}\text { Movendo-se em direção à extremidade } \\
\text { Movendo-se em direção ao centro }\end{array}$ \\
\hline Centro & Qualquer que seja o movimento \\
\hline
\end{tabular}

Tabela 2.1: Situações possiveis para o rato a cada instante no Modelo de Inércia de Giddings e Archibald [18].

Em 2009 foi publicado um artigo de Miranda et al. [20] com um modelo computacional de ratos no LCE baseado em [19]. Nele, uma RNA determina as quatro possíveis ações do rato virtual: ir para frente, para trás, virar para esquerda ou para a direita. A rede é treinada por retro-propagação, um tipo de aprendizagem supervisionada. São parâmetros do modelo: densidade de iluminação, paredes, alturas e nível de novidade. O nível de novidade é representado por um valor que decai ao longo da simulação, mas é sempre constante em qualquer posição do labirinto. A altura da parede é representada por uma variável que recebe um alto valor quando o rato virtual se encontra em um braço fechado e por um valor pequeno quando ele está em um braço aberto (muitos LCEs têm uma pequena parede nos braços abertos apenas para evitar a queda do animal). Esse artigo compara as permanências e entradas em cada braço e a soma de todas as entradas para ratos virtuais e experimentais.

Outra abordagem foi adotada no modelo de Shimo et al. [21], no qual o agente virtual é obtido através de um processo de otimização. Diferentemente dos modelos anteriores, que usaram aprendizado supervisionado para o treinamento das RNAs, 
neste modelo as RNAs foram otimizadas por algoritmos genéticos (AGs). A RNA controla a estratégia do robô em uma réplica do LCE. A função de avaliação compara diretamente o resultado de saída obtido por AGs com os resultados pretendidos, isto é, dados experimentais conhecidos a priori. A análise do modelo foi feita comparando a porcentagem de tempo gasta nos braços abertos e fechados, bem como o número de entradas em cada tipo de braço, por ratos reais e pelo robô evolutivo.

Em um dos livros-chave de computação evolutiva [31], os autores discutem que a função de avaliação pode ser escolhida segundo dois diferentes métodos. No primeiro, a função carrega explicitamente as habilidades e limitações do agente inteligente, restringindo suas ações. Nesse caso, o agente aprende a executar uma tarefa específica, determinada pelo programador. Este método foi o adotado em [21]. Já no segundo método, a função de avaliação é baseada em critérios gerais do problema, os quais conduzem o agente automaticamente a limitações e habilidades devido a sua interação com o ambiente. Esse método simula melhor um processo de evolução natural do agente [31].

O presente trabalho de doutorado apresenta os modelos mais recentes para o comportamento exploratório de ratos no LCE (propostos por nós), os quais são variações do modelo de Ken et al. [21]. Também associamos RNAs com AGs (esses métodos computacionais são introduzidos no Capítulo 3), porém utilizamos uma função de avaliação genérica, como implica o segundo método de escolha da função de avaliação comentado livro de Nolfi e Floreano [31]. Ao contrário dos outros modelos já mencionados, o agente (RNA) é construído sem a utilização explícita de resultados experimentais de ratos reais. A função é baseada no conflito medo/ansiedade de ratos, sendo composta por dois termos: um que promove a exploração de novas posições no LCE e outro que representa a aversão a situações perigosas, conforme sua posição no labirinto. Resultados desta pesquisa foram publicados em diversos artigos [23, 24, 25, 26].

Para a análise do comportamento do rato no LCE, Tejada et al. [22] sugeriram o uso de cadeias de Markov [32], as quais já vêm sendo utilizadas há décadas para descrever o comportamento de vários animais [33, 34, 35]. Os processos Markovianos são um tipo particular de processos estocásticos. Nos processos estocásticos como um todo, a transição de um estado para outro (no espaço) depende de um número 
finito ou infinito de estados anteriores do agente. Nos processos Markovianos, $k=1$, ou seja, apenas o estado atual do agente é utilizado para a tomada de decisão de sua próxima ação. A partir das matrizes Markovianas calculadas para ratos reais, Tejada et al. [22] simularam o comportamento de ratos virtuais baseados em tomadas de decisão estocásticas para as transições entre as posições do LCE. As probabilidades de transição vêm das matrizes Markovianas de transições de ratos reais. Os tempos de permanência e entradas simulados para cada tipo de braço são significativamente menores do que os de ratos reais. Uma descrição de como obter as cadeias Markovianas decorrentes da trajetória de ratos é descrita no Capítulo 4.

Parte da análise dos resultados apresentados no Capítulo 5 vem da confrontação das cadeias de Markov de ratos reais com as cadeias de Markov oriundas de nossas simulações. Outros resultados são comparações do tempo de permanência em cada tipo de braço, o número de entradas em cada um deles, o número de chegadas às extremidades abertas e fechadas e o número de movimentações em cada tipo de braço. Vale salientar que pela segunda vez um modelo computacional está sendo usado para reproduzir não apenas o comportamento de ratos que não foram expostos a drogas (ratos controle), mas também de ratos sob o efeito de ansiogênicos (drogas para aumentar a ansiedade) e ansiolíticos (drogas para reduzir a ansiedade). O modelo de Tejada et al. depende diretamente de resultados de ratos reais e produz resultados limitados. Já os autores Miranda et al. afirmaram que o modelo proposto por eles é capaz de reproduzir o comportamento de ratos sob o efeito de drogas, porém não exibiram resultados deste tipo no artigo publicado [20].

Em muitos trabalhos $[6,36,37,38,39]$, experimentos vêm sendo realizados com ratos reais sob efeito de drogas e, como esperado, ansiogênicos costumam fazer com que ratos aumentem sua ansiedade e, como consequência, passem mais tempo nos braços fechados do que os ratos controle; logicamente o contrário ocorre devido ao uso de ansiolíticos. Estes comportamentos foram reproduzidos e são mostrados no Capítulo 5. 


\section{Capítulo}

\section{Redes neurais artificiais e algoritmos genéticos}

Neste capítulo explicamos o que são e como funcionam os métodos computacionais aplicados em nosso modelo: redes neurais artificiais e algoritmos genéticos.

\subsection{Redes neurais artificiais}

Com o desenvolvimento dos computadores digitais surgiu a ideia de representar por meio de programas computacionais o funcionamento dos neurônios. Na década de 1940, a tentativa de simular redes de neurônios deu origem à área de pesquisa de redes neurais artificiais. Nas pesquisas envolvendo RNAs, busca-se modelos inspirados no funcionamento básico de redes de neurônios que possuam a capacidade de aprender e se adaptar a eventuais mudanças [40]. O objetivo normalmente é observar a emergência de um comportamento inteligente, tal como a aprendizagem de novas tarefas e a capacidade de generalização, provenientes de descobertas, erros e acertos feitos pela rede. Para um bom entendimento de o que são e como funcionam as redes neurais artificiais, pode-se checar o Apêndice A para saber mais sobre o funcionamento de sistemas nervosos reais.

Uma RNA é composta por uma coleção de unidades, comumente chamadas de "neurônios" (e às vezes de "nós"), conectadas entre si. A cada conexão é atribuído um "peso", como em um grafo ponderado. Essas conexões são usadas para transmitir sinais de um neurônio para outro, como as sinapses em uma rede 
neuronal biológica [31].

\subsubsection{Arquitetura de RNAs}

Em um RNA, os neurônios são divididos em camadas, sendo a arquitetura da rede definida pelo número de camadas, pela disposição dos neurônios em cada camada, pela topologia das conexões e pelo tipo de função(ões) de ativação dos neurônios. O número mínimo de camadas que uma RNA pode possuir é dois: uma camada de entrada e uma de saída. Apesar de este tipo de rede possuir duas camadas, recebe o nome de rede monocamada, pois apenas uma camada realiza processamento de informação, isto é, possui neurônios (a camada de saída). A camada de entrada possui unidades sensoriais responsáveis pela captação dos sinais de entrada, ou seja, apenas captam, não realizam processamento de informações. A rede neural artificial é multicamada quando, além das camadas de entrada e saída, possui camada(s) internas(s). As camadas internas também são chamadas de escondidas, intermediárias ou ocultas [41]. A Figura 3.1 mostra uma RNA multicamada com duas camadas intermediárias. Os círculos indicam neurônios, os quais processam sinais vindos de suas entradas de acordo uma de ativação, a qual pode variar de modelo para modelo. É muito comum o uso de funções de ativação sigmoidais. Os quadrados indicam as unidades sensoriais.

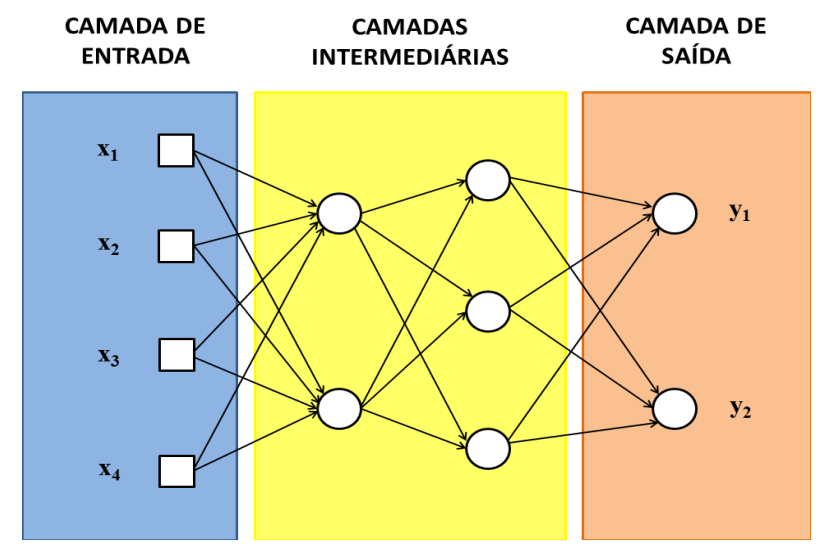

Figura 3.1: Diagrama de uma rede neural artificial multicamada sem recorrência, com duas camadas intermediárias. As unidades sensoriais são representadas pelos quadrados, enquanto os neurônios são representados pelas elipses.

Os principais tipos de conexões dos neurônios são: sem recorrência ou recorrente. Nas redes sem recorrência (também conhecidas como feedforward, diretas ou 
acíclicas), o sinal percorre a rede em uma única direção, da camada de entrada para a de saída, sendo que os neurônios da mesma camada não são conectados entre si. Em outras palavras, neurônios da $i$-ésima camada não podem emitir sinal para neurônios em camadas com índice menores ou iguais a $i$. Um exemplo de rede sem recorrência consta na Figura 3.1. Já as redes recorrentes (feedback ou cíclicas) são aquelas cujo grafo de conectividade possui ao menos um ciclo, ou seja, a saída de pelo menos um neurônio na $i$-ésima camada se liga a ao menos um neurônio de uma camada de índice menor ou igual a $i$ [40], como mostram as Figura 3.2(a) e (b). A característica da realimentação qualifica estas redes para processamento dinâmico, isto é, podem ser usadas em sistemas que variam no tempo e necessitam de memória.
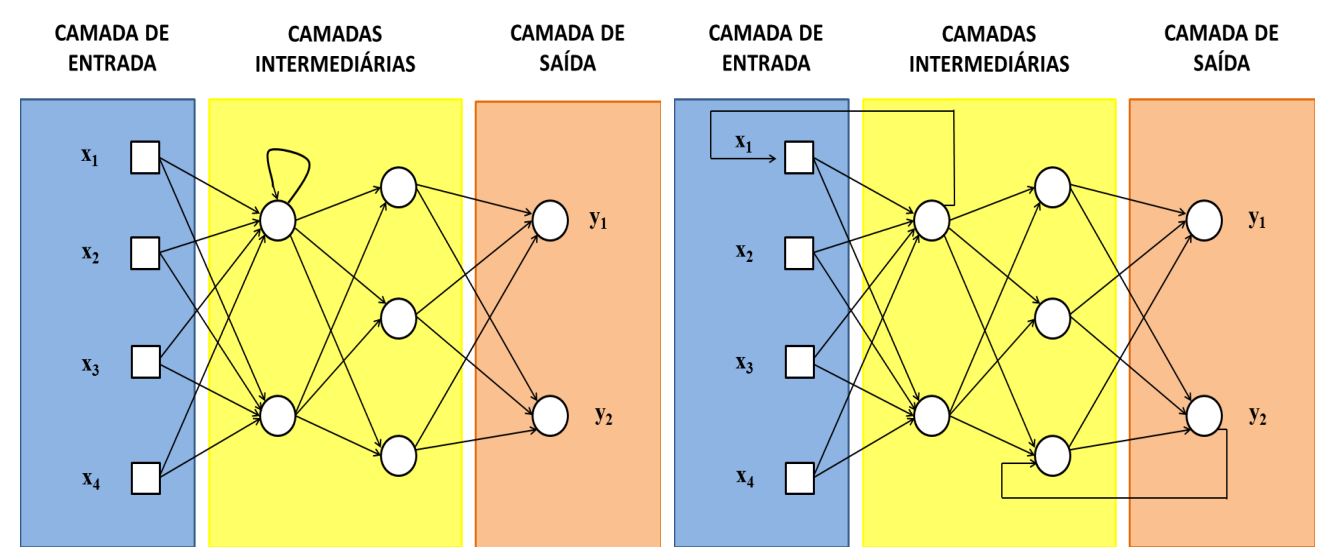

Figura 3.2: Diagrama de duas redes recorrentes diferentes.

\subsubsection{Aprendizado}

Em geral, uma RNA passa por um período de aprendizado (treinamento), no qual os pesos da rede são ajustados de forma que ela se adapte aos diferentes estímulos que recebe. Para isso, precisa extrair informações e padrões dos estímulos fornecidos a ela. Um algoritmo que descreve uma sequência definida de passos por meio do qual a RNA aprende alguma tarefa é chamado de algoritmo de aprendizado. O tipo de aprendizado depende da maneira com a qual são realizados os ajustes dos parâmetros da rede. Existem essencialmente três tipos de aprendizado: supervisionado, não supervisionado e por avaliação da qualidade das soluções, que inclui alguns tipos de aprendizado realizados por reforço e por algoritmos evolutivos. 


\subsubsection{Aprendizado supervisionado}

O aprendizado supervisionado é o método mais comum de treinamento de RNAs. Recebe este nome porque são fornecidos para a rede o conjunto de entradas e de saídas desejado, como se houvesse um supervisor determinando qual deve ser a saída para cada entrada. A rede deve ser capaz de medir a diferença entre seu comportamento atual e o comportamento de referência, modificando seus pesos de modo a diminuir o erro. O propósito é otimizar os parâmetros da rede (geralmente os pesos) para que possa responder adequadamente às entradas esperadas e extrapolar esse conhecimento para entradas que não foram previstas no treinamento [40]. Este tipo de aprendizado depende da existência das saídas desejadas para o treinamento.

\subsubsection{Aprendizado não supervisionado}

No aprendizado não supervisionado não é fornecida nenhuma referência externa ao sistema, salvo as entradas. Os pesos da rede são modificados em função de critérios internos, como, por exemplo, a repetição de padrões de ativação de neurônios [40]. O principal interesse no uso desse tipo de aprendizado é desvendar padrões existentes nos dados agrupando-os. Esta abordagem é muito usada em mineração de dados (data mining), quando a rotulação dos dados não é conhecida antecipadamente [40].

\subsubsection{Aprendizado por avaliação da qualidade das soluções}

Este tipo de aprendizado tem como estratégias principais o aprendizado por reforço e alguns tipos de aprendizado realizados por algoritmos evolutivos (o qual será tratado posteriormente neste trabalho). No aprendizado por avaliação da qualidade das soluções, a RNA recebe apenas informações parciais do ambiente, como, por exemplo, o sucesso ou insucesso na execução de uma tarefa. A rede aprende por tentativa e erro, otimizando-se um índice de desempenho.

O aprendizado por reforço tem motivação biológica, afinal, na natureza, conforme estudos da abordagem da Psicologia conhecida por Behaviorismo, comportamentos podem ser reforçados, tanto positivamente quanto negativamente, para que sua frequência de ocorrência seja aumentada. Ou seja, um reforço positivo aumenta a probabilidade de um comportamento por meio da presença de uma 
recompensa, ao passo que o reforço negativo também aumenta a probabilidade de um comportamento pela ausência (retirada) de um estímulo aversivo (que cause desprazer) após o organismo apresentar o comportamento em questão [42]. Assim, comportamentos que trazem satisfação costumam ter como consequência um reforço das conexões neurais que as produziram.

Ao contrário do reforço, a punição é um estímulo aversivo que reduz a probabilidade de um comportamento. Por isso, por exemplo, pais repreendem seus filhos quando fazem algo errado; a punição tende a gerar uma mudança de comportamento dos filhos (alteração nas conexões), de modo que a criança passa a evitar a repetição de seu erro [43].

Nos casos de aprendizado por avaliação da qualidade das soluções, o sinal de avaliação produzido pelo ambiente é usado para adaptar as conexões da RNA sem o conhecimento da saída desejada. Diferentemente do aprendizado supervisionado, as ações do rato em cada instante de tempo não são utilizadas como saídas desejadas para treinar a rede. Ao invés disso, aprende-se utilizando a avaliação da trajetória realizada pelo rato virtual (solução do algoritmo de otimização). Ou seja, diferentemente do aprendizado não supervisionado, utiliza-se informação do ambiente para treinar a RNA. Repare que, como dito, não importam as ações a cada instante de tempo. Assim, o aprendizado por avaliação da qualidade das soluções foi o tipo de aprendizado utilizado neste trabalho, pois a informação ambiental é importante para a movimentação de ratos, porém a ação específica do roedor a cada passo de tempo não é relevante ao se analisar o comportamento médio do animal (diferentes ratos apresentam diferentes sequências de ações e, consequentemente, diferentes trajetórias).

\subsubsection{Tipos de rede}

Existem vários tipos de rede, sendo os mais populares: perceptron, perceptron multicamada (MLP), rede de Hopfield e rede de Kohonen.

- Perceptron: também conhecido por single-layer perceptron, é a rede neural artificial sem recorrência mais simples, com uma camada de entrada e uma de saída. Em aprendizado de máquinas, o perceptron é um algoritmo usado para classificação supervisionada linear [44]. 
- Multilayer perceptron (MLP): enquanto o perceptron é usado em problemas linearmente separáveis, o MLP pode ser aplicado em problemas não linearmente separáveis. O MLP contém ao menos uma camada intermediária, com um número de neurônios definido a priori. O algoritmo de treinamento mais comum é o de retropropagação, que é um tipo de aprendizado supervisionado [45].

- Hopfield: funciona como uma memória associativa, analogamente à memória humana, sendo ativada pelo conteúdo da informação. A associação de memória acontece, por exemplo, quando nos lembramos de um fato completo a partir de uma pequena lembrança do acontecimento ou lembramos de alguma outra coisa de conteúdo similar à lembrança inicial. Para isso, a Rede de Hopfield consiste em um conjunto de neurônios com atrasos unitários na passagem da informação entre neurônios, ocasionados por um sistema com realimentação, porém sem auto alimentação, ou seja: a saída de um neurônio alimenta todos os outros neurônios, exceto ele mesmo [46].

- Kohonen: este tipo de rede é também conhecido como mapa auto organizável. Esta classe de RNAs utiliza métodos de aprendizado não supervisionado, tipicamente o aprendizado competitivo, no qual os neurônios competem para responder a uma entrada sensorial (estímulo) apresentado. Assim, os neurônios se organizam topologicamente em grupos de neurônios responsáveis por diferentes estímulos [45].

No presente trabalho, utilizamos o MLP com conexões recorrentes na camada escondida, chamado de rede de Elman [46].

\section{$3.2 \quad$ Algoritmos genéticos}

Algoritmos Genéticos (AGs) são estratégias de otimização e busca inspirados nos mecanismos de evolução dos seres vivos. Otimização é a busca da melhor solução para um dado problema, testando várias soluções e utilizando as informações obtida neste processo de forma a encontrar soluções cada vez melhores [47]. Estes algoritmos seguem o princípio da seleção natural proposta por Darwin no livro "A 
Origem das Espécies" [48], em 1859. De acordo com Charles Darwin, quanto mais um indivíduo se adaptar ao ambiente, maiores serão suas chances de sobreviver e deixar descendentes. Nas próximas seções trazemos um breve relato histórico sobre a origem e desenvolvimento da computação baseada na evolução dos seres vivos e um detalhamento dos elementos presentes nos AGs e de quando estes métodos computacionais são válidos. Para mais informações, uma descrição da terminologia biológica básica utilizada nos algoritmos genéticos pode ser consultada no Apêndice B.

\subsubsection{Breve história da computação evolutiva}

A primeira tentativa de representação matemática da teoria Darwiniana da seleção natural se deu com a publicação do livro The Genetic Theory of Natural Selection [49], escrito pelo estatístico e biólogo evolucionista Ronald Aylmer Fisher, em 1930. No livro, o autor ressalta a importância dos experimentos de Gregor Mendel, apresentados em 1865, e afirma que a seleção natural e a evolução são tratadas, muitas vezes, indistintamente; o que não está certo. Assim, discutiu em seu livro especificamente a seleção natural, fazendo uso de seus conhecimentos de estatística. Ele mostrou matematicamente que uma mutação benéfica pode alterar a população de uma espécie ao longo das gerações e discutiu que isso nem sempre é uma coincidência tão grande, pois tal mutação pode ter ocorrido outras vezes antes de se estabelecer efetivamente na população. Além disso, demonstrou que a taxa de mutação deve ser bem pequena para que uma mutação benéfica possa se propagar e por isso loci homólogos são praticamente idênticos em cada espécie isolada. Também estabeleceu uma relação entre o surgimento de novas mutações e a extinção de genes.

Durante as décadas de 1950 e 1960, vários pesquisadores estudaram de forma independente os sistemas evolucionários, aproveitando a ideia de que os processos naturais adaptativos presentes na evolução podem ser usados como ferramentas de otimização. Todos eles seguiram o mesmo raciocínio de evoluir uma população de soluções candidatas para os problemas estudados, usando operadores de variabilidade genética e seleção natural [50]. Basicamente três tipos básicos de algoritmos foram desenvolvidos independentemente nessa época em computação evolutiva: 
- Programação evolutiva: proposta em 1962 nos Estados Unidos por L. J. Fogel [51]. Na proposta inicial, diagramas de transição de máquinas de estados finitos eram evoluídos através de mutação e elitismo. Uma máquina de estado finito [52], representa uma sequência de instruções a serem realizadas conforme o estado atual da máquina e o estímulo recebido, assim como um programa computacional.

Atualmente é tipicamente utilizada em otimização de soluções compostas por parâmetros que assumem valores reais. Não usa o operador de recombinação e a seleção é feita geralmente por método semelhante ao torneio. Além disso, a mutação geralmente é aleatória com distribuição Gaussiana, com média zero e valor de variância adaptável. Existe ainda um operador de mutação alternativo baseado na distribuição de Cauchy [53].

- Algoritimo genético: as primeiras versões de algoritmos semelhantes aos atuais algoritmos genéticos e testes de suas aplicações foram feitas por Fraser em 1962 [54] e em 1968 [55], Bremermann em 1962 [56] e em 1965 com colaboradores [57], e Holland em 1962 [58], 1969 [59] e 1975 [60]. Holland foi o principal responsável pelo desenvolvimento do que se conhece hoje como algoritmos genéticos. Goldberg, um dos alunos de Holland, ajudou a difundir os algoritmos genéticos, principalmente por meio do livro Genetic Algorithms in Search, Optimization and Machine Learning [1], que é hoje um dos livros mais importantes sobre AGs. Este método de otimização foi o que usamos no presente trabalho e será mais bem descrito nas próximas seções.

- Estratégia evolutiva: introduzida por Rechenberg em 1965 e também por Schwefel, no mesmo ano, na Alemanha. Tipicamente utilizada em otimização de soluções compostas por parâmetros que assumem valores reais. Esse tipo de estratégia inicialmente foi usado em problemas de otimização relacionados à mecânica de fluidos, trabalhando com um único indivíduo na população. Em seguida passou a tratar da otimização de funções mais genéricas, enfocando o caso das funções reais [61]. A auto-adaptação de parâmetros da estratégia é uma das características chaves do sucesso das estratégias evolutivas (bem como da programação evolutiva), pois utiliza processos evolutivos para otimizar o 
espaço de atributos e o espaço de parâmetros. Os parâmetros da estratégia são aqueles que controlam o processo evolutivo de busca, como taxa de recombinação e desvio padrão da mutação. Costuma ter seleção aleatória com distribuição uniforme para a escolha dos pais para reprodução, seleção elitista para a escolha dos indivíduos da próxima geração, recombinação e mutação Gaussiana com possível auto-adaptação dos parâmetros de mutação [62].

O avanço desses métodos, que já apresentavam demonstrações impressionantes de sua capacidade mesmo com as grandes limitações de hardware da época, culminou, ainda, no desenvolvimento de sistemas classificadores [63] e da programação genética [64].

Na programação genética, os indivíduos da população não são sequências de bits, mas sim programas de computador armazenados na forma de árvores sintáticas. Tais programas são os candidatos à solução do problema proposto. A programação genética geralmente não usa operador de mutação e a recombinação se dá pela troca de subárvores entre dois indivíduos candidatos à solução.

Hoje em dia, quando se fala sobre AGs, normalmente está-se referindo a um método já bem diferente daquele proposto por Holland em 1962 [50]. Além disso, não há um consenso absoluto sobre a definição de cada um dos métodos da computação evolutiva. Para uma revisão e um aprofundamento destas técnicas, algumas referências são confiavelmente recomendadas: [1, 50, 61, 64, 65].

\subsubsection{Elementos dos AGs}

Antes de explorarmos os elementos existentes nos algoritmos genéticos, é preciso ressaltar que não há uma definição única e rigorosa, aceita por todos que fazem uso da computação evolutiva, diferenciando esta técnica das demais de CE. Porém, alguns elementos costumam ser padrões nos AGs: população representada por cromossomos, seleção de indivíduos dependente de sua aptidão, função objetivo para o cálculo da aptidão, recombinação e mutação para produzir uma nova geração e aumentar a variabilidade genética na população.

O procedimento de um AG começa pela geração de uma população inicial de indivíduos (cromossomos). Durante a execução do AG, esta população é avaliada, de modo que cada indivíduo receba uma nota (chamada de aptidão do indivíduo), que 
mostra a qualidade da solução a qual ele corresponde. Normalmente os indivíduos mais aptos são selecionados, podendo ser alterados por meio de recombinação e mutação durante a reprodução, produzindo descendentes para a próxima geração. Já os indivíduos menos aptos da população costumam ser descartados. Esse mecanismo reflete a seleção natural proposta por Darwin e é repetido até que algum critério de convergência, como tempo de simulação, número de gerações ou valor de aptidão (dentre outros) seja atingido. A Figura 3.3 exibe um AG típico.

Seja $S(t)$ a população de cromossomos na geração $t$ (comentário)

$t \leftarrow 0$

inicializar $S(t)$

avaliar $S(t)$

enquanto o critério de parada não for satisfeito faça

$t \leftarrow t+1$

selecionar $S(t)$ a partir de $S(t-1)$

aplicar recombinação sobre $S(t)$

aplicar mutação sobre $S(t)$

avaliar $S(t)$

\section{fim enquanto}

Figura 3.3: Algoritmo genético típico [47].

Cada um dos elementos presentes no AG será explicado a seguir.

\subsubsection{Representação}

O AG evolui uma população inicial de indivíduos (cromossomos). O cromossomo é uma estrutura de dados que representa uma das possíveis soluções do problema a ser otimizado. Na representação binária, cada elemento do vetor mostra a ausência (bit 0) ou a presença de alguma característica (bit 1). Este tipo de representação é a mais utilizada devido à facilidade de manipulação e análise teórica, sem mencionar o apelo histórico por ter sido usada nos trabalhos pioneiros de Holland, em 1992. Contudo, a representação usando números reais é mais facilmente compreendida e necessita de menos memória do que a representação binária [66].

Na evolução artificial, cada indivíduo, assim como na evolução natural, possui um fenótipo e um genótipo. O fenótipo equivale a uma solução para o problema em 
questão, enquanto o genótipo é a representação genética do fenótipo. O genótipo é que é transmitido através das gerações e está diretamente sujeito aos operadores do AG [67]. Os elementos que atuam na população, por exemplo selecionando-a ou modificando-a, são chamados de operadores.

A população inicial pode ser gerada pelo AG de diferentes maneiras, por exemplo:

- aleatoriamente seguindo alguma função (linear, exponencial, quadrada,...);

- tendenciosamente para regiões promissoras do espaço de busca;

- inserindo a solução obtida por outro método de otimização na população inicial, garantindo que o AG não tenha desempenho pior que o outro método;

- com uma larga população inicial aleatória, reduzindo o tamanho ao longo da evolução.

Como dito anteriormente, um cromossomo representa, em geral, um conjunto de parâmetros da função objetivo cuja resposta deseja-se maximizar ou minimizar. O espaço de busca de soluções é dado pelo conjunto de todas as configurações que o cromossomo pode assumir. Se o cromossomo representa $n$ parâmetros de uma função, então o espaço de busca tem $n$ dimensões [47].

\subsubsection{Seleção}

Inspirado no processo de seleção natural de seres vivos, o algoritmo genético seleciona indivíduos da população - geralmente aqueles com alta aptidão - para gerar cromossomos filhos (variantes dos pais) através dos operadores de recombinação e mutação. Os descendentes constituem a geração seguinte. Geralmente, os pais são selecionados com probabilidade proporcional à sua aptidão para gerar descendentes. Existem muitos métodos para fazer essa seleção. Exemplos são: seleção Boltzman, seleção por roleta, por torneio, por elitismo, por classificação, por estado estacionário, entre outros. Descreveremos os métodos de seleção mais comumente utilizados, que são: seleção por elitismo, por roleta e por torneio.

- Seleção por elitismo: neste tipo de seleção, $k$ indivíduos com as melhores aptidões da população são selecionados para continuarem na próxima geração 
sem serem alterados, ou seja, sem passarem pelos operadores de reprodução (recombinação e mutação). Isto evita que possível(is) boa(s) solução(ões) não seja(m) perdida(s). É comum utilizar $k=1$; aumentando o valor de $k$, aumenta-se a pressão seletiva, isto é, o risco de o sistema convergir prematuramente a uma solução que não seja necessariamente a solução ótima para o problema.

- Seleção por roleta: neste método, cada indivíduo da população é representado em uma roleta proporcionalmente à sua aptidão. Assim, aos indivíduos com alta aptidão é dada uma porção maior da roleta, enquanto aos de aptidão mais baixa é dada uma porção relativamente menor da roleta. Finalmente, a roleta é girada um determinado número de vezes escolhido, dependendo do tamanho da população, e aqueles indivíduos sorteados na roleta são selecionados para se reproduzirem, deixando descendentes para a próxima geração.

Essa é a ideia do que acontece implicitamente no método da roleta. Na prática, a aptidão de todos os indivíduos da população é somada e normalizada. Um valor aleatório entre zero e um é sorteado e é a aptidão relativa de cada indivíduo que determina a faixa de valores que representa cada um deles, como ilustra o exemplo contido na Figura 3.4. Este processo pode ser realizado de maneira equivalente, sorteando um número aleatório entre zero e a soma da aptidão de todos os indivíduos; neste caso, a faixa de valores que representa cada membro da população depende diretamente da aptidão deles e não mais da aptidão relativa. Na seleção por roleta, a pressão seletiva é menor do que na seleção por elitismo.

Outro método de seleção é semelhante à roleta, chamado de seleção por classificação (ou por ranking), com a diferença de que a probabilidade de seleção é relacionada também à ordenação dos indivíduos conforme sua aptidão antes do sorteio. A ordenação pode ser, por exemplo, decrescente, linear ou exponencial. [68] 


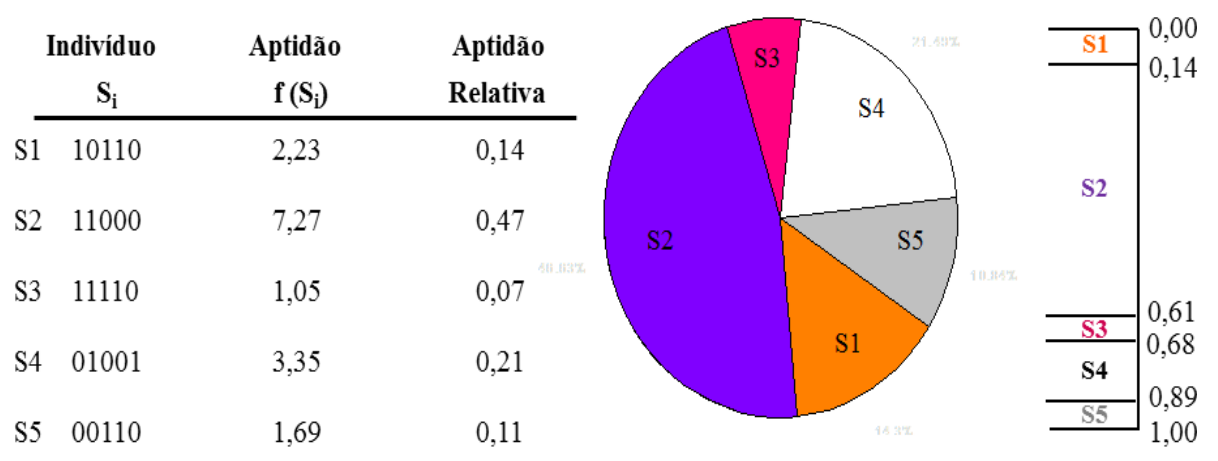

Figura 3.4: Indivíduos de uma população e a sua correspondente roleta de seleção.

- Seleção por torneio: existem dois tipos de implementação do torneio. No primeiro, dois indivíduos são sorteados e o melhor deles é escolhido com probabilidade $p_{s}$. No segundo, $k$ indivíduos são sorteados e o melhor deles é escolhido. Aumentando-se $p_{s}$ ou diminuindo-se $k$, aumenta-se a pressão seletiva. A possibilidade de se controlar a pressão seletiva é a principal vantagem do método. O processo de torneio é repetido até que o número de pais que originarão a população da geração seguinte seja atingido.

É possível, e é o que normalmente se faz, combinar mais de um tipo de seleção para gerar a próxima população, aproveitando as vantagens e suavizando as desvantagens de cada método.

\subsubsection{Função de aptidão}

O propósito da otimização realizada pelo AG é maximizar (ou minimizar) uma função de aptidão (também chamada de adequação, custo, objetivo ou fitness). Sendo assim, um dos aspectos mais importantes do desenvolvimento de AGs é a escolha de uma função de aptidão apropriada. Esta função avalia cada indivíduo de cada geração, atribuindo-lhes uma nota, que reflete a sua aptidão em resolver o problema estudado. Quanto mais apto for o indivíduo, maiores suas chances de ser selecionado para se reproduzir. Isso reflete a noção evolutiva de que apenas os indivíduos mais aptos sobrevivem e conseguem se reproduzir, gerando "bons" filhos que também sobrevivam. 


\subsubsection{Recombinação}

A recombinação é o elemento que mais distingue os AGs das outras estratégias em computação evolutiva [50]. Este operador é aplicado, com dada probabilidade (chamada de taxa de recombinação), em pares de indivíduos eleitos anteriormente pelo operador de seleção. Não ocorrendo a recombinação, os filhos serão iguais aos pais. A recombinação e a mutação são operadores necessários para que a população se diversifique e mantenha características de adaptação adquiridas pelas gerações anteriores [47]. Os tipos mais comuns de recombinação (também chamada de cruzamento ou crossover) são:

- Recombinação de um ponto: neste método, um ponto de recombinação é escolhido aleatoriamente e a partir dele é realizada troca de material genético entre dois indivíduos. A informação genética anterior ao ponto de um pai se liga à informação posterior ao ponto de outro pai, gerando um filho [66]. A combinação oposta gera outro filho, como é representado na Figura 3.5. Essa foi a estratégia de recombinação adotada no presente trabalho.

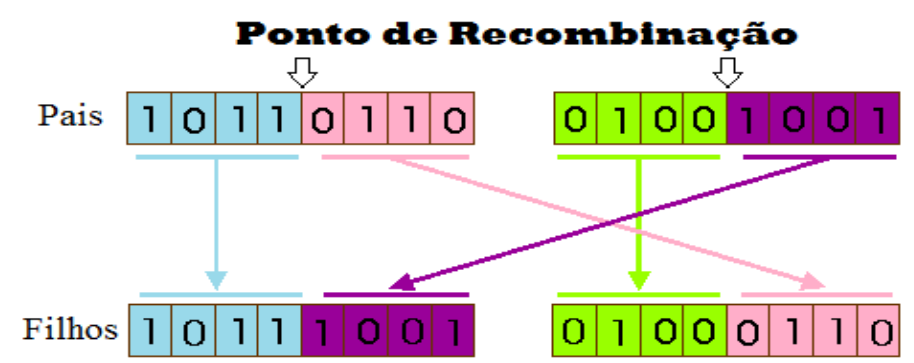

Figura 3.5: Esquema gráfico da recombinação de um ponto. O ponto de recombinação escolhido foi a posição quatro do cromossomo. Figura adaptada de [69].

- Recombinação multipontos: a recombinação genética é feita de modo semelhante a da recombinação de um ponto, considerando, no entanto, mais de um ponto de recombinação entre os cromossomos pais. A Figura 3.6 exemplifica uma recombinação de dois pontos.

- Recombinação uniforme: o cruzamento uniforme não se baseia em pontos de cruzamento, mas sim em máscaras que determinam os genes de qual pai o filho herdará. As máscaras são escolhidas aleatoriamente. Onde houver "1" na 


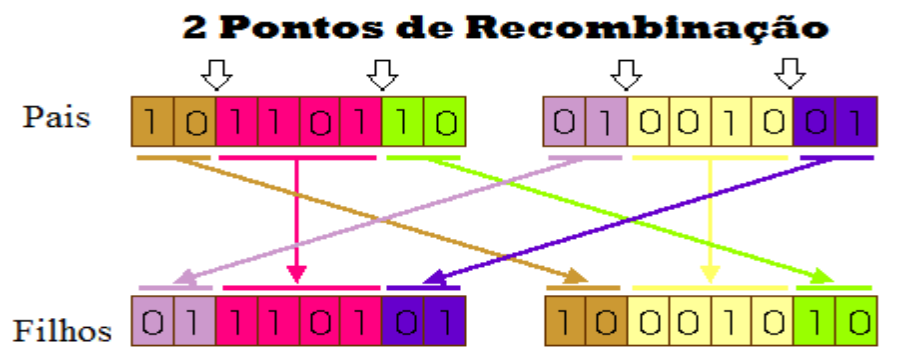

Figura 3.6: Esquema gráfico da recombinação de dois pontos, com os pontos de recombinação dois e seis. Figura adaptada de [69].

máscara de cruzamento, o gene correspondente será copiado do primeiro pai e, onde houver "0" será do segundo pai. Esse processo é repetido trocando-se os pais para produzir o segundo descendente. Uma nova máscara de cruzamento é criada para cada par de pais. A Figura 3.7 ilustra esta estratégia de cruzamento.

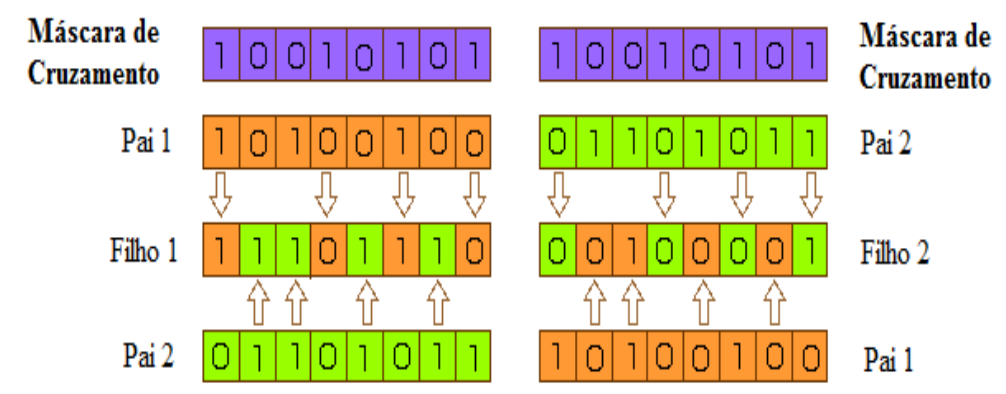

Figura 3.7: Esquema gráfico do cruzamento uniforme. Figura adaptada de [69].

\subsubsection{Mutação}

Como já foi mencionado, a mutação é um operador reprodutivo que proporciona, assim como o cruzamento, variabilidade genética à população. A mutação é aplicada, com certa probabilidade (chamada de taxa de mutação), nos cromossomos resultantes de cruzamento, modificando arbitrariamente um ou mais de seus genes. Quando a representação do cromossomo é binária, a mutação em um gene acontece pela inversão do bit correspondente, como retrata a Figura 3.8. Quando a representação é feita através de números inteiros ou reais, métodos mais complexos são necessários para mutar um gene. Nesses casos, é comum se usar as seguintes estratégias [70]: 
- Mutação uniforme: substitui o gene por um número aleatório dentro dos limites permitidos para ele;

- Mutação de limite: substitui o gene por um dos limites do intervalo factível a ele;

- Mutação não-uniforme: substitui um gene por um número extraído de uma distribuição não-uniforme (seja linear, exponencial, Lorentziana, etc.);

- Mutação gaussiana: é um método bastante utilizado. Substitui o gene por um número aleatório de uma distribuição gaussiana com média e desvio padrão determinados no AG;

- Mutação creep: adiciona ao parâmetro pequeno valor aleatório obtido a partir de distribuição uniforme ou normal.

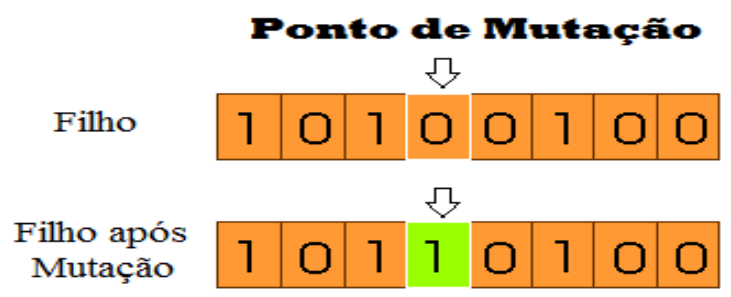

Figura 3.8: Esquema gráfico de ocorrência de mutação. Na representação binária, a mutação ocorre por inversão do bit. Figura adaptada de [69].

\subsubsection{Parâmetros do AG}

Após a apresentação de todos os elementos do AG, vale dizer que não há valores ideais para cada parâmetro do modelo que garantam bons resultados para todos os tipos de problemas. O mais importante ao implementar o AG é equilibrar todos os parâmetros entre si, conforme o problema que se pretende solucionar. Uma discussão dos principais parâmetros é feita abaixo:

- Tamanho da população: O tamanho da população afeta o desempenho e a eficiência dos AGs. Se a população é grande, o espaço de busca é, em geral, vastamente preenchido, evitando uma convergência precoce. Contudo, 
isso requer mais tempo de simulação e maiores recursos computacionais. Se a população é pequena, há uma rápida diminuição da diversidade, podendo facilmente convergir para soluções ruins [66]. Para contornar estes problemas, costuma-se executar o algoritmo várias vezes, com diferentes sementes de números aleatórios.

- Taxa de cruzamento: Quanto maior for esta taxa, mais rapidamente novas estruturas (novas áreas do espaço de busca) poderão ser exploradas. Entretanto, se esta for muito alta, indivíduos com boas aptidões poderão ser excluídos velozmente. Com um valor baixo, o algoritmo pode requerer muito tempo de simulação [66].

- Taxa de mutação: Uma baixa taxa de mutação previne que uma dada posição fique estagnada em um valor, sem causar drásticas alterações. Com uma taxa muito alta a busca do ótimo acaba se tornando praticamente aleatória [66]. Geralmente faz-se com que a taxa de mutação corresponda a um gene no total de genes do cromossomo.

- Critério de parada: Como mencionado, são diversos os possíveis critérios de parada do algoritmo. Os mais comuns são: tempo de simulação, número de gerações, valor de aptidão médio ou do melhor indivíduo estável. Para escolher é conveniente considerar quais critérios são mais significativos para cada problema.

\subsubsection{Quando funcionam os AGs}

Algoritmos genéticos são complexos e nem sempre são o método mais eficiente para solucionar um problema. Embora existam muitos exemplos de sucesso do uso de AGs, em outros casos eles funcionam pobremente. Não existe uma resposta única sobre quando convém serem utilizados, mas muitos pesquisadores discutem que podem ser comparáveis ou melhores que outras técnicas de otimização principalmente nas situações em que o espaço de busca seja multimodal, que a função objetivo seja ruidosa e que o encontro de um ótimo local da função seja suficiente, não carecendo necessariamente do ótimo global. Isso porque um espaço de busca grande e desconhecido inviabiliza sua varredura exaustiva, pois a melhor 
solução não pode ser rapidamente encontrada. Além disso, uma função objetivo unimodal e pouco ruidosa pode ser facilmente explorada por métodos baseados em gradiente, como de subida íngrime (hill climbing) [50] (para mais informações sobre o método de hill climbing, consultar [71]). As principais vantagens dos algoritmos genéticos são, portanto: robustez, pouca influência em seu desempenho decorrente de descontinuidades no espaço de busca e não requisição de conhecimentos prévios dos gradientes da função objetivo. A Figura 3.9 mostra um espaço de busca grande e multimodal.

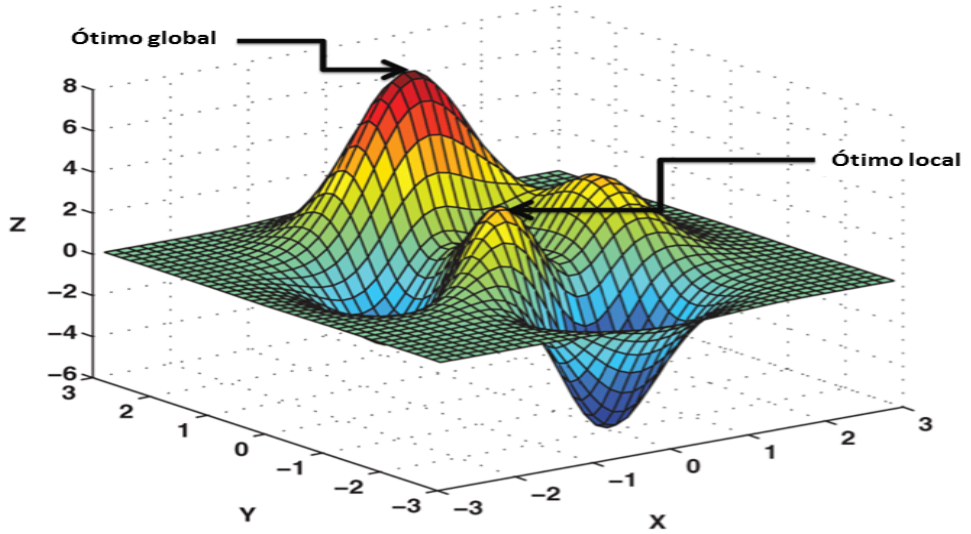

Figura 3.9: Representação gráfica de um espaço de busca grande e multimodal, denotando seu o ótimo global e um ótimo local. Figura adaptada de [72].

Assim, selecionamos redes neurais evoluídas por algoritmos genéticos para investigar o comportamento do rato no labirinto em cruz elevado dadas as qualidades supramencionadas para esse método. 


\section{Capítulo}

\section{Métodos da pesquisa}

Neste capítulo, os métodos implementados na pesquisa são apresentados. Trabalhamos com dados de ratos reais e de dois modelos computacionais diferentes, comparando os resultados.

\subsection{Experimentos com ratos reais}

Os dados das trajetórias de ratos reais vêm de experimentos publicados em [22, 73]. Nesses experimentos foram usados ratos Wistar machos adultos, pesando entre 210 e 230 g, criados no biotério do campus de Ribeirão Preto da Universidade de São Paulo. Os ratos são expostos ao labirinto pela primeira vez, cada um sob efeito de determinada condição farmacológica. As condições farmacológicas consideradas nos testes foram: administração de droga ansiolítica (clordiazepóxido, CDP, na concentração de $5 \mathrm{mg} / \mathrm{kg}$ - 10 ratos), ansiogênica (semicarbazida, SCZ, nas concentrações de 20, 40 e $80 \mathrm{mg} / \mathrm{kg}$ - 11 ratos de cada) e sem efeito de drogas (ratos controles -47 ratos $)^{1}$. Cada rato foi colocado sozinho no mesmo labirinto para andar livremente por 5 minutos. Após os 5 minutos de experimento, cada rato foi retirado do labirinto, que foi limpo com álcool para remover vestígios do animal antes que outro animal fosse colocado no LCE para o experimento. Uma câmera filmadora foi utilizada para registro de todos experimentos para posterior análise.

\footnotetext{
${ }^{1}$ É interessante observar que em experimentos com ratos reais, os ratos controle recebem uma injeção de solução salina antes dos experimentos, pois só a injeção (mesmo sem nenhuma substância psicotrópica) já estressa o rato e altera seu comportamento. Por isso, para compará-los com justiça a ratos sob efeito de drogas, os ratos controle recebem a injeção de solução salina.
} 
Estes experimentos foram realizados pelos (na época) alunos Julian Tejada, Andrea M. G. Becerra, Ana Cristina M. Costa e Javier Leonardo R. Rodriguez para a realização de diferentes pesquisas. Os dados nos foram gentilmente cedidos pelo Prof. Dr. Silvio Morato, coordenador do Laboratório de Comportamento Exploratório da Faculdade de Filosofia, Ciências e Letras de Ribeirão Preto da Universidade de São Paulo, no qual foram realizados os experimentos. Os dados cedidos são arquivos de texto obtidos com o software X-Plo-Rat, desenvolvido sob supervisão do Prof. Dr. Silvio Morato. Esse software permite um registro manual das ações realizadas pelo rato no LCE nas diferentes posições do labirinto a partir da visualização dos vídeos dos experimentos. O número de posições por braços do LCE podem ser delimitados pelo pesquisador.

As ações contidas nos registros não são apenas transições entre posições ${ }^{2}$, mas também comportamentos ditos etológicos (inatos, instintivos) do animal. Esses comportamentos registrados foram:

- Mergulho (dipping): o rato mergulha a cabeça para baixo, fora do labirinto para explorar;

- Esticamentos(stretching): o animal estica o corpo, mantendo as patas traseiras em uma posição, alcançando outra posição com as patas dianteiras;

- Levantamentos (rearing): o rato fica em pé, o que ocorre principalmente nas proximidades das paredes dos braços fechados. É um modo de explorar seu entorno;

- Auto-limpeza (cleaning ou grooming): o roedor se coça, limpando-se. Vale lembrar que o (auto-)toque traz uma sensação reconfortante/calmante (o que ocorre também em outros animais, inclusive humanos);

- Congelamento (freezing): um tipo de comportamento raro no qual o rato fica paralisado em situações de muito estresse;

- Defecação: o rato evacua fezes. Quanto mais nervoso, maior o número de dejetos.

\footnotetext{
${ }^{2}$ Nos registros foram consideradas transições apenas as situações em que o animal colocou as patas traseiras na posição seguinte.
} 
Todos esses comportamentos são característicos do animal e sua frequência de ocorrência pode evidenciar uma elevação ou diminuição da ansiedade do roedor. Contudo, no presente trabalho consideramos apenas as transições entre posições, com a intenção de simplificar o problema, que, ainda assim, é de considerável complexidade.

\subsection{LCE virtual}

O LCE virtual considerado neste trabalho é o mesmo labirinto bidimensional proposto em [19] (ver Figura 4.1(a)). Para facilitar a modelagem e a análise dos dados, o labirinto em cruz elevado é discretizado. Cada braço é dividido em cinco posições, totalizando 21 posições em todo o labirinto, incluindo a posição central. É nesse labirinto que o rato virtual caminha enquanto é avaliado. Entretanto, podemos considerar que os braços fechados são indistinguíveis entre si, assim como os braços abertos - como mostra a Figura 4.1(b), - pois durante o experimento tenta-se manter condições constantes de temperatura, pressão, luminosidade, etc. Assim, para a análise dos resultados usamos uma versão simplificada labirinto (como em [19]), conforme mostra a Figura 4.1(c). Neste labirinto reduzido, as posições 1-5 correspondem aos braço abertos, 6 é a posição central e as posições 7-11 representam os braços fechados. Essa aproximação reduz a variabilidade comportamental do modelo, facilitando a análise dos resultados. 


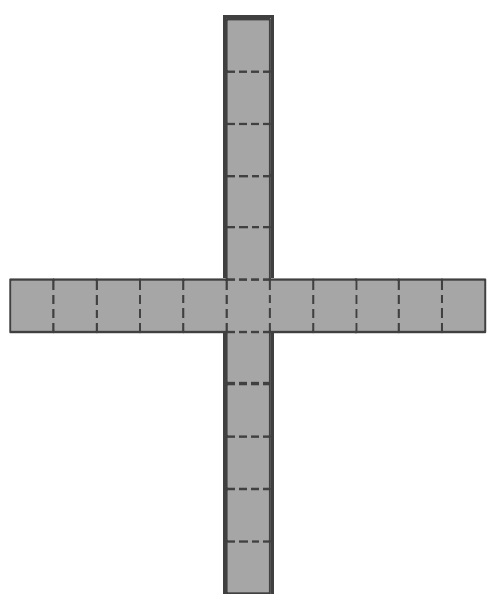

(a)

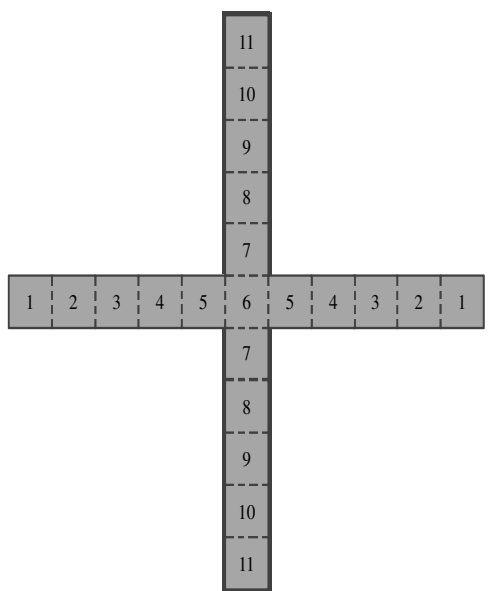

(b)

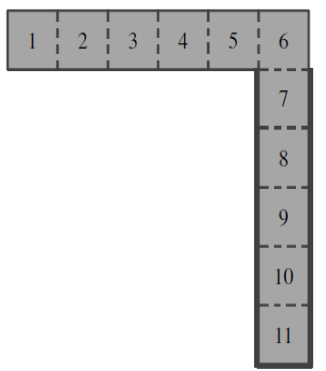

(c)

Figura 4.1: (a) O labirinto completo exibido na figura constitui o espaço de navegação de ratos reais e virtuais durante o experimento; (b) os braços fechados são considerados indistinguíveis entre si para análise do comportamento do rato, assim como os braços abertos; (c) o labirinto reduzido, composto apenas por linhas pretas sólidas na figura, é usado para análise dos resultados. As posições 1-5 representam os braços abertos do labirinto. O braço com a linha em negrito representa o braço fechado do LCE reduzido (posições 7-11). A posição 6 corresponde ao centro.

\subsection{Modelo computacional 1 - rede estática}

Trabalhamos com dois modelos computacionais semelhantes para investigar o comportamento do rato no LCE. Descreveremos agora as características do primeiro modelo estudado. 


\subsubsection{Rede neural artificial}

O agente computacional - chamado de rato virtual, - é controlado por um MLP recorrente (rede de Elman), com dez elementos na camada de entrada (seis sensores e quatro realimentações da camada intermediária), quatro neurônios na única camada intermediária e quatro na camada de saída. Os sensores provêm da percepção das paredes ao redor (ou não) do agente, equivalendo a sensores localizados em volta de um robô. A Tabela 6.1 retrata a função de cada sensor do rato virtual. Como se pode observar na tabela, são três sensores de curta distância (esquerda, direita e frente) e três similares de longa distância. Os sensores de curta distância captam paredes apenas na posição atual do rato, enquanto os de longa distância são capazes de detectar paredes a 3 posições de distância do agente virtual (a atual e mais duas).

Tabela 4.1: Entradas sensoriais do rato virtual. A angulação de $0^{\circ}$ é considerada como a frente do rato. A direção é usada para representar as posições dos sensores de paredes no agente. Os sensores de curto alcance detectam paredes apenas na posição atual do rato virtual, enquanto os de longo alcance abrangem duas posições além de sua posição atual.

\begin{tabular}{|c|c|c|}
\hline Sensor & Direção & Alcance \\
\hline \hline 1 & Direita & Curta distância \\
2 & Frente & Curta distância \\
3 & Esquerda & Curta distância \\
4 & Direita & Longa distância \\
5 & Frente & Longa distância \\
6 & Esquerda & Longa distância \\
\hline
\end{tabular}

As saídas da RNA indicam a próxima ação do robô (ir para frente, virar à esquerda na mesma posição, virar à direita na mesma posição, ou ficar parado). A escolha é dada pelo maior valor de ativação dentre os neurônios de saída. O comportamento representado pelo neurônio selecionado é executado.

Escolhemos uma rede recorrente, pois ela permite que entradas anteriores sejam levadas em consideração para o cálculo das ativações dos neurônios internos da rede (agindo como uma memória interna), o que é importante porque o próximo movimento do rato pode depender das últimas posições que visitou. A rede 
resultante é representada na Figura 4.2.

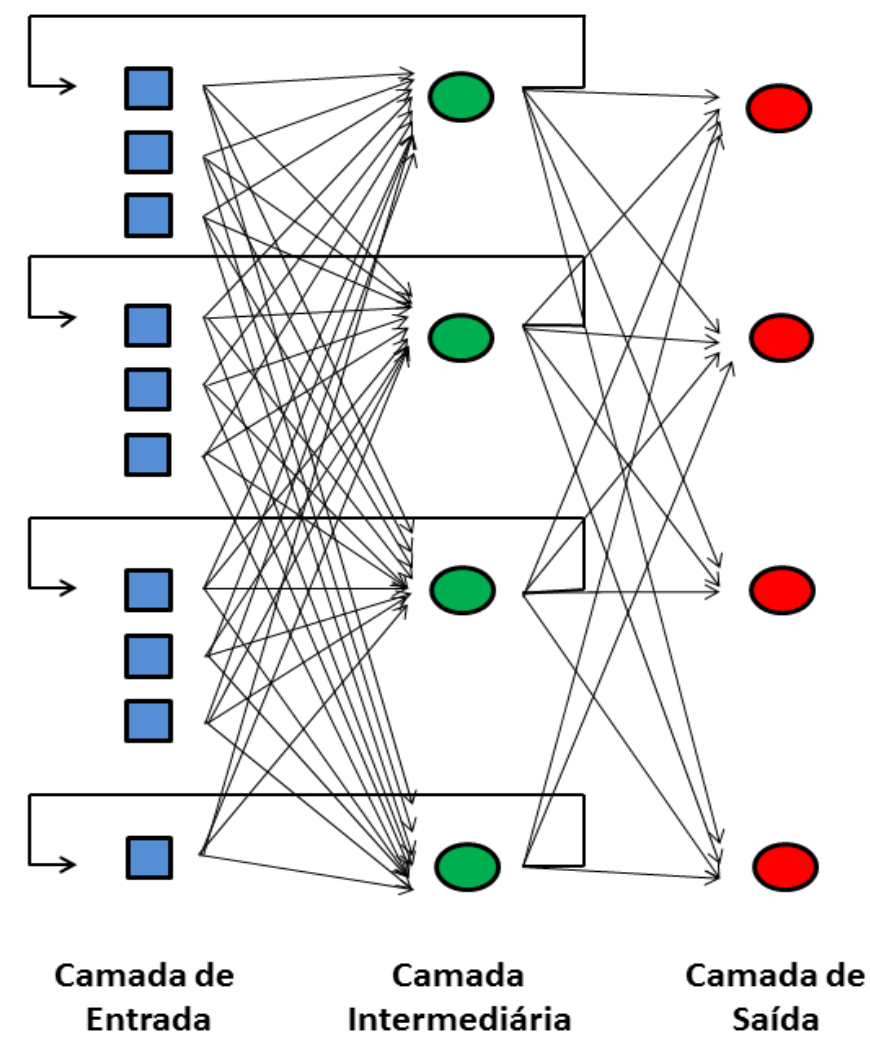

Figura 4.2: Esquema representativo da rede neural que define o rato virtual. A rede é composta por 10 elementos de entrada (6 sensores e 4 elementos realimentados pela camada intermediária), 4 neurônios recorrentes e 4 neurônios de saída.

O resultado de saída de cada neurônio $i$ da camada intermediária e de saída é calculado através de uma função sigmoidal:

$$
y_{i}=\frac{1}{1+e^{-u_{i}}},
$$

onde:

$$
u_{i}=\sum_{j=1}^{p} w_{i j} a_{j},
$$

sendo $w_{i j}$ os pesos sinápticos entre os neurônios pós-sinápticos $i$ e pré-sinápticos $j, p$ o número total de neurônios pré-sinápticos de $i$, e $a_{j}$ as ativações dos neurônios pré-sinápticos ou das unidades sensoriais (para os neurônios da camada intermediária). É importante ressaltar que o modelo contém sinapses tanto excitatórias $\left(w_{i j} \geq 0\right)$ como inibitórias $\left(w_{i j}<0\right)$. 


\subsubsection{Algoritmo genético}

Para este modelo, não podemos aplicar métodos de treinamento supervisionado, como retropropagação, pois não são definidas as saídas da rede desejadas em cada instante de tempo. Assim, os pesos sinápticos da RNA são otimizados por um algoritmo genético. Sendo assim, cada indivíduo da rede corresponde a um cromossomo, composto por um vetor de números reais (entre 6,0 e -6,0), que representa uma possível combinação dentre os conjuntos de pesos permitidos para a RNA. Ou seja, cada vetor equivale a um rato virtual, que é uma possível solução para o problema.

A população inicial (geração um) do AG, composta por 1.000 indivíduos, é escolhida aleatoriamente. Cada indivíduo é avaliado após navegar no labirinto virtual durante 300 passos de tempo (300 iterações da RNA); supondo que dure um segundo cada passo, as 300 iterações corresponderão aos 300 segundos (cinco minutos), que é p tempo padrão dos experimentos no LCE com ratos reais. Com base em sua aptidão, os indivíduos são selecionados por elitismo e torneio. Por elitismo, dois indivíduos são selecionados para passarem para a próxima geração sem serem alterados. No torneio, o melhor entre dois indivíduos aleatórios é selecionado, com probabilidade 0,75 , para passar pelos operadores de reprodução. . Isso é feito sorteando-se um número aleatório no intervalo entre 0 e 1 e escolhendo o melhor indivíduo se este número for menor que 0,75 ; caso contrário, o outro indivíduo é escolhido. O torneio é realizado até que tenhamos um número de indivíduos suficientes para completar a população, cujo tamanho é mantido ao longo de toda a simulação. Os indivíduos selecionados por torneio passam então por recombinação de um ponto, com probabilidade de $60 \%$, e por mutação gaussiana, com a probabilidade de $5 \%$ e desvio padrão de $5 \%$, dando origem a uma nova população. Esse processo é repetido por 15.000 gerações. Estes parâmetros foram selecionados em um período de seleção de parâmetros, no qual várias combinações foram testadas. Isso foi feito não apenas durante nossa pesquisa, mas também em trabalhos anteriores de nosso grupo de pesquisa.

Em cada simulação computacional realizada, esse algoritmo é executado 30 vezes, cada vez com uma semente aleatória diferente. Este procedimento é importante porque a população inicial e os operadores de seleção e reprodução são estocásticos. 
Um esboço do algoritmo genético utilizado é apresentado na Figura 4.3.

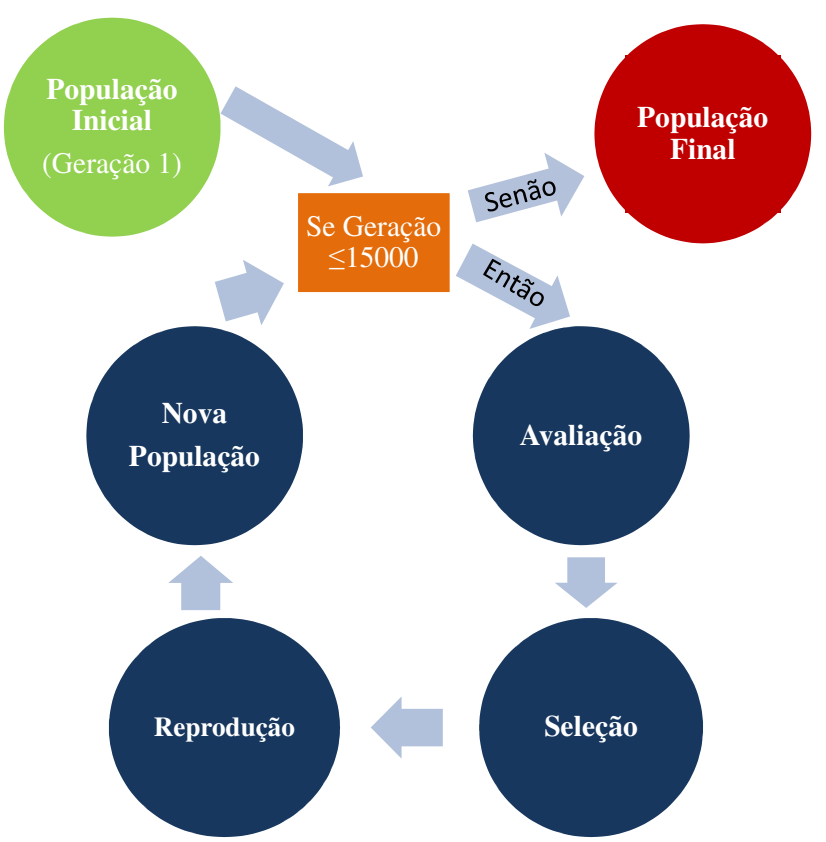

Figura 4.3: Esquema das etapas do algoritmo genético. Os resultados são obtidos com populações de 1.000 indivíduos evoluídos durante 15.000 gerações. Os resultados são obtidos para 30 execuções do $A G$.

A aptidão (ou fitness) do indivíduo é calculada com base na trajetória percorrida pelo agente (rato virtual). Como já discutido anteriormente, essa a função de avaliação é baseada no modelo comportamental que sugere um conflito entre medo do ambiente desconhecido e interesse em explorá-lo, proposto por Montgomery [2]. A função de avaliação proposta neste trabalho de doutorado é composta de dois termos: um de recompensa e outro de punição. A recompensa representa a curiosidade, o interesse do rato em explorar posições que não foram visitadas recentemente no labirinto. Este termo aumenta a aptidão do indivíduo (é um termo positivo na equação). Por outro lado, a punição decresce a aptidão do indivíduo, representando sua exposição ao perigo. Sabe-se que o rato evita o perigo permanecendo mais tempo nos braços fechados. Desta forma, o nível de perigo é diferente para diferentes posições do labirinto, sendo, por exemplo, maior nos braços abertos. Quanto mais o rato se expõe, maior a chance de ser punido, isto é, a punição é probabilística, 
conforme a posição ocupada no labirinto.

A função de avaliação $f(\mathbf{x})$ para o cromossomo do indivíduo x é dada por:

$$
f(\mathbf{x})=\sum_{t=1}^{n} r\left(\mathbf{x}, p_{t}\right)+s\left(\mathbf{x}, p_{t}\right) \beta
$$

A definição de cada parâmetro da Eq. 4.3 é dada na Figura 4.4, a qual exibem também o valor utilizado para cada parâmetro nas simulações. Como mencionado, os dois termos da equação simulam possíveis situações de punição e recompensa utilizadas para adaptação do rato devido à seleção natural e/ou aprendizado. O parâmetro $\beta$, que controla o peso da punição, simula o efeito de drogas no rato.

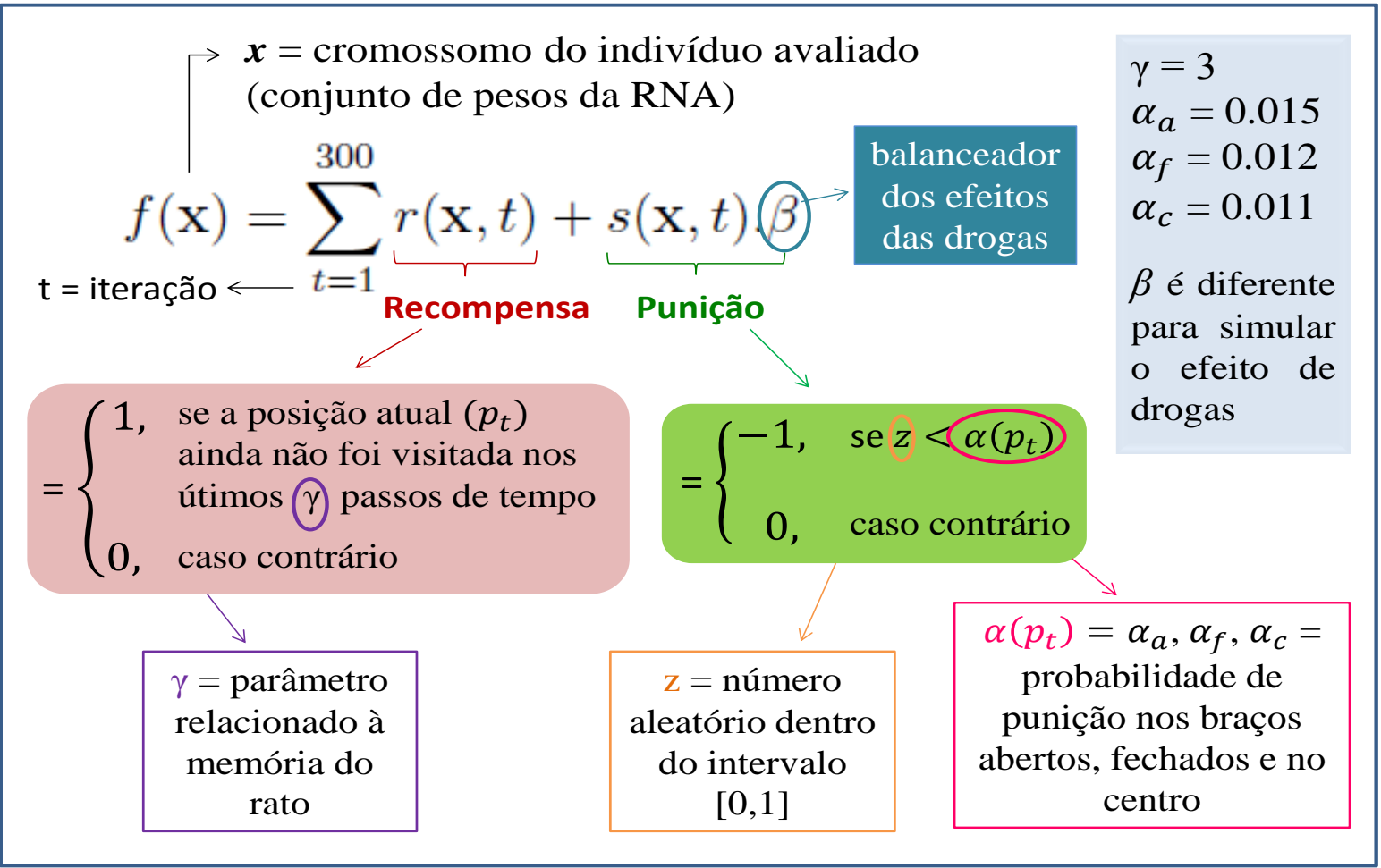

Figura 4.4: Função de avaliação e valores de seus parâmetros utilizados no modelo.

Cada região do labirinto (braços abertos, fechados ou centro) expõe o animal a possíveis situações perigosas, o que é representado no modelo pela função $\alpha\left(p_{t}\right)$, que determina a probabilidade de punição do agente virtual dada a região em que ele se encontra. A probabilidade de punição nos braços abertos é maior do que nas outras regiões (braços fechados e centro), pois sabemos que os braços abertos são 
mais perigosos para o animal porque ele fica mais vulnerável a predadores e pode cair do labirinto, por exemplo.

Considerando os ratos reais, podemos associar a recompensa do animal à informação ambiental que ele recebe ao explorar o labirinto. Dessa forma, a maior punição nos braços abertos pode ser também interpretada como a redução de informação sensorial recebida pelo animal devido à falta de contato das vibriças com o ambiente (exceto a base do labirinto).

A escolha dos valores dos parâmetros usados na função de avaliação foi feita após diversos testes realizados com diferentes combinações de valores. Devido à estocasticidade presente na avaliação do indivíduo, temos um problema de otimização evolutiva incerta, existindo diferentes estratégias para lidar com problemas deste tipo, como discutimos em [24]. Uma delas é considerar a aptidão do indivíduo a cada geração como uma média de várias avaliações; deste modo é mais seguro que o valor da aptidão calculado reflita melhor a qualidade do indivíduo como solução do problema em questão. Outro método para suavizar incertezas é evoluir o algoritmo genético por muitas gerações, o que é outro modo de submeter os indivíduos a várias avaliações [24]. O segundo método foi adotado neste trabalho.

\subsection{Modelo computacional 2 - rede evolutiva}

O segundo modelo estudado é bastante semelhante ao primeiro. O rato virtual também é representado por uma rede neural artificial evoluída por um algoritmo genético. A diferença nesse caso é que não apenas os pesos da RNA são evoluídos pelo AG, mas também a arquitetura da rede. Enquanto no primeiro modelo a rede neural é composta por um número fixo de sensores (seis) e quatro neurônios intermediários recorrentes, agora a rede pode ter no máximo 6 sensores e no máximo 4 neurônios recorrentes na camada intermediária. O valor mínimo de neurônios nessas camadas é 1. O número de neurônios na camada de saída continua sendo fixo (quatro - cada um representando um possível comportamento do rato: avançar para a próxima posição, virar para a esquerda permanecendo na mesma posição, virar para a direita na mesma posição, ou ficar parado). O controle do número de unidades (unidades sensoriais ou neurônios) em cada camada é feito pelo algoritmo genético. Para isso, 
cada indivíduo do AG é representado por dois cromossomos: o de pesos, exatamente igual ao do modelo 1, e outro da arquitetura. Esse cromossomo da arquitetura é um vetor de 10 elementos binários (0 ou 1), cada um representando a presença (1) ou ausência (0) da respectiva unidade sensorial ou neurônio na rede. Os quatro primeiros elementos do vetor são referentes aos neurônios da camada intermediária. Os próximos seis são referentes às unidades sensoriais (sensores da Tabela 4.1).

Com essa alteração no modelo, a recombinação também foi alterada, pois agora o indivíduo sofre recombinação de um ponto (com a probabilidade de $60 \%$ ) no cromossomo da arquitetura, bem como no cromossomo de pesos da rede. Depois da possível recombinação, tanto os alelos do cromossomo de pesos quanto da arquitetura podem sofrer mutação com probabilidade de $5 \%$ (binária no caso dos alelos que representam os neurônios e Gaussiana com desvio padrão de 5\% no caso dos alelos que correspondem aos pesos sinápticos).

Uma vantagem desse segundo modelo em relação ao primeiro é que a arquitetura das redes neurais evolui a partir do algoritmo genético. Dessa forma são reduzidas as incertezas causadas pelo planejamento "manual" da rede, o qual depende de conhecimento prévio e/ou especulações do programador sobre o problema em questão. Com essa evolução da arquiteturas das redes neurais (ratos virtuais) além da evolução dos pesos sinápticos entre os elementos da rede, espera-se que apenas os sensores e neurônios mais necessários para a trajetória do rato no labirinto sejam selecionados probabilisticamente (através do AG). A seleção da arquitetura mostra quais os tipos de informações sensoriais são mais importantes para a tomada de decisão do rato (agente) no LCE e também permite a investigação do uso de memória por meio da seleção dos neurônios da camada oculta.

\subsection{Análise dos resultados}

Para avaliar a qualidade do modelo precisamos de métodos para comparar as trajetórias de ratos reais e virtuais no LCE. Sendo assim, foram registrados médias e desvios padrões do tempo gasto em cada tipo de braço, do número de entradas em cada um deles, do número de vezes que o rato atinge as extremidades dos braços abertos e fechados e do número de movimentos em cada um dos tipos de braços. 
Para os ratos reais, os resultados correspondem ao conjunto de todos os ratos sob uma determinada condição (com ou sem um tipo de droga). Para os ratos virtuais, os resultados foram obtidos com o melhor indivíduo de cada uma das 30 execuções do AG para um determinado valor do parâmetro $\beta$.

Além destas análises, utilizamos cadeias de Markov, como sugerido em [22] para analisar as transições entre posições nas trajetórias. Para isso, calculamos a matriz Markoviana estocástica de primeira ordem $P$, cujos elementos $p_{i j}$ representam a probabilidade de transição de uma posição $i$ do labirinto para uma posição adjacente $j$. Os valores são normalizados de modo que a soma da cada linha da matriz seja um, pois representa a soma das probabilidades de todas as transições que o rato pode fazer a partir de uma posição do LCE, considerando que o rato só pode se mover para posições adjacentes. Assim, no máximo dois elementos são diferentes de zero a cada linha da matriz. Não são consideradas as situações em que o rato permanece na mesma posição de um instante para o outro porque nosso interesse no uso de cadeias de Markov é justamente a análise dos comportamentos médios de deslocamento do rato (real e virtual).

Conhecendo as frequências de transição entre as posições $i$ e $j$, as probabilidades de transição são estimadas pelo Princípio da Máxima Verossimilhança:

$$
\hat{p}_{i j}=\frac{f_{i j}}{\sum_{j=1}^{11} f_{i j}},
$$

onde $i, j=1,2, \ldots, 11$, sendo $i \neq j$, são as posições do LCE reduzido. Pode-se ainda calcular o vetor de probabilidades de estado estacionário $\pi[22]$ :

$$
\pi P=\pi
$$

Cada um dos 11 elementos de $\pi$ indica a probabilidade de encontrar o rato na respectiva posição do LCE reduzido durante um experimento, no estado estacionário. Assim:

$$
\sum_{i=1}^{11} \pi_{i}=1 .
$$

Esses resultados são apresentados no próximo capítulo. 


\subsection{Análise das trajetórias e redes neurais artificiais}

Para estudar as arquiteturas das redes neurais, montamos tabelas concatenando as quantidades de sensores e neurônios, e os tipos de sensores dos melhores indivíduos de 30 execuções de simulação de ratos controles.

As análises das trajetórias são feitas a partir de gráficos com as trajetórias discretizada de ratos reais e virtuais no labirinto. No caso dos ratos virtuais, apresentamos também o gráfico das orientações do rato a cada passo de tempo. Para facilitar, incluímos também esquemas contendo os percursos do rato virtual em ilustrações do LCE.

Para finalizar, exibimos gráficos com as ativações das unidades de entrada e neurônios da rede em função do passo de tempo computacional com a finalidade de estudar a tomada de decisão do rato virtual e a importância de cada entrada e neurônio em sua trajetória.

Esses resultados são apresentados no Capítulo 6. 


\section{Capítulo}

\section{Resultados: parâmetro $\beta$}

Neste capítulo testaremos a influência do parâmetro $\beta$ no comportamento do rato virtual. Também analisaremos a possibilidade de utilização desse parâmetro para caracterização do efeito de drogas ansiogênicas e ansiolíticas no animal.

Os registros de ratos reais utilizados nesta pesquisa (fornecidos pelo grupo do Laboratório de Comportamento Exploratório liderado pelo Prof. Dr. Silvio Morato de Carvalho) são baseados nas trajetórias de 47 ratos controle (de vários experimentos diferentes), 11 ratos sob efeito de semicarbazida nas concentrações de $20 \mathrm{mg} / \mathrm{kg}, 40 \mathrm{mg} / \mathrm{kg}$ e $80 \mathrm{mg} / \mathrm{kg}$ (droga ansiogênica) e 10 ratos sob efeito de clordiazepóxido $5 \mathrm{mg} / \mathrm{kg}$ (droga ansiolítica). Já os resultados de simulação são provenientes da média dos melhores indivíduos de 30 execuções de 15000 gerações do AG, com população de 1000 indivíduos.

Os primeiros resultados aqui mostrados são comparações da média do tempo de permanência em cada tipo de braço (Figura 5.1.(a)), o número de movimentações em cada tipo de braço (Figura 5.1.(b)), o número de entradas e de chegadas às extremidades abertas e fechadas (Figura 5.1.(c)), para ratos controle reais e virtuais. Para facilitar a visualização, abreviamos "braços abertos" como "BA" e "braços fechados" como "BF". Como os dados são assimétricos e as amostras são pequenas, o teste estatístico escolhido para verificar se não existe diferença estatística entre os dados dos ratos reais e virtuais foi o Mann-Whitney. Neste teste não paramétrico, a hipótese nula considera que as duas amostras comparadas (ratos reais e virtuais) são da mesma população. No teste, as amostras são ranqueadas e os ranques são usados para compará-las. Esse teste permite o aceite ou a rejeição da hipótese nula sem a 
necessidade de que as amostras sejam do mesmo tamanho. O nível de significância considerado no teste foi 0,05 .

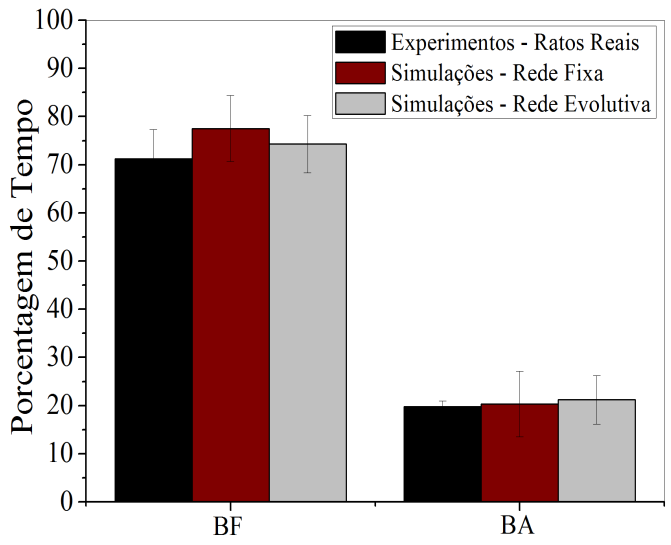

(a)

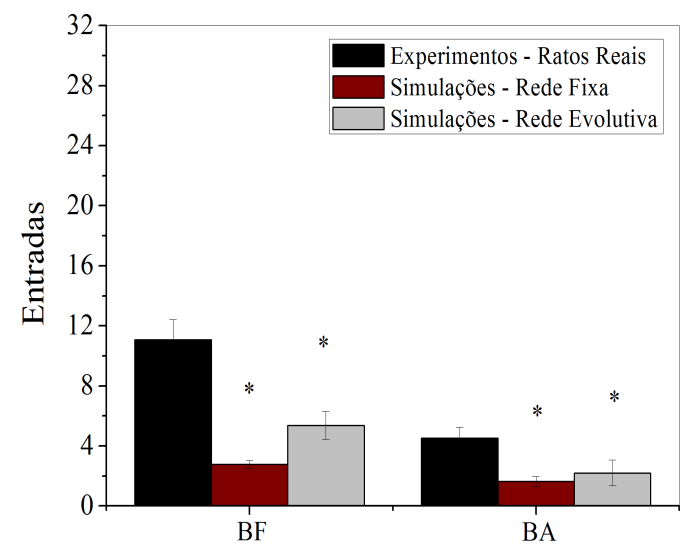

(c)

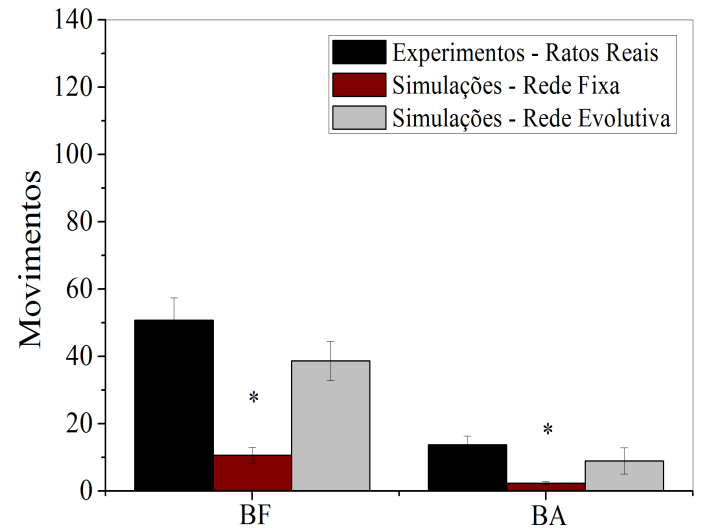

(b)

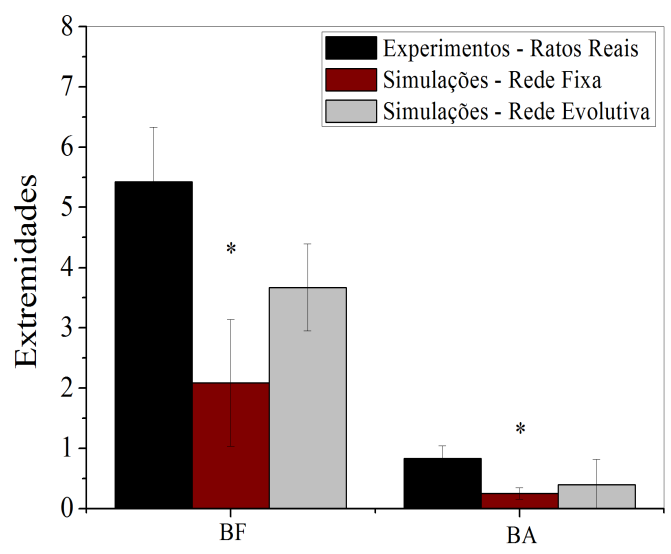

(d)

Figura 5.1: Média e erro padrão (a) do tempo de permanência nos braços abertos e fechados, (b) da quantidade de movimentos feitos em cada tipo de braço, (c) do número de entradas $e(d)$ chegadas às extremidades em cada tipo de braço para ratos reais e virtuais em testes de cinco minutos no LCE. Para otimização dos ratos virtuais, foi-se utilizado $\beta=3,2$. O símbolo * indica quando é possivel afirmar que os resultados dos ratos reais e virtuais são de populações diferentes de acordo com o teste Mann-Whitney com nivel de significância 0,05.

Comparados aos ratos reais, os ratos virtuais com redes evolutivas obtiveram melhores resultados que os ratos virtuais com rede fixa, como evidenciado pelo teste Mann-Whitney. Das oito variáveis analisadas, apenas duas não foram aprovadas pelo teste: o número de entradas nos braços fechados e abertos. No caso das simulações com rede neural artificial fixa, apenas os tempos de permanência nos dois tipos 
de braços foram aprovados pelo teste estatístico. Nota-se que os ratos virtuais se movimentam menos e, consequentemente, entram menos nos diferentes tipos de braços e chegam menos vezes às extremidades do que os ratos reais.

$$
\mathrm{P}=\left(\begin{array}{ccccccccccc}
0 & 1,00 & 0 & 0 & 0 & 0 & 0 & 0 & 0 & 0 & 0 \\
0,35 & 0 & 0,65 & 0 & 0 & 0 & 0 & 0 & 0 & 0 & 0 \\
0 & 0,46 & 0 & 0,54 & 0 & 0 & 0 & 0 & 0 & 0 & 0 \\
0 & 0 & 0,44 & 0 & 0,56 & 0 & 0 & 0 & 0 & 0 & 0 \\
0 & 0 & 0 & 0,45 & 0 & 0,55 & 0 & 0 & 0 & 0 & 0 \\
0 & 0 & 0 & 0 & 0,34 & 0 & 0,66 & 0 & 0 & 0 & 0 \\
0 & 0 & 0 & 0 & 0 & 0,42 & 0 & 0,58 & 0 & 0 & 0 \\
0 & 0 & 0 & 0 & 0 & 0 & 0,47 & 0 & 0,53 & 0 & 0 \\
0 & 0 & 0 & 0 & 0 & 0 & 0 & 0,48 & 0 & 0,52 & 0 \\
0 & 0 & 0 & 0 & 0 & 0 & 0 & 0 & 0,54 & 0 & 0,46 \\
0 & 0 & 0 & 0 & 0 & 0 & 0 & 0 & 0 & 1,00 & 0
\end{array}\right)
$$

(a) Ratos reais

$$
\mathrm{P}=\left(\begin{array}{ccccccccccc}
0 & 1,00 & 0 & 0 & 0 & 0 & 0 & 0 & 0 & 0 & 0 \\
0,85 & 0 & 0,15 & 0 & 0 & 0 & 0 & 0 & 0 & 0 & 0 \\
0 & 0,90 & 0 & 0,10 & 0 & 0 & 0 & 0 & 0 & 0 & 0 \\
0 & 0 & 0,89 & 0 & 0,11 & 0 & 0 & 0 & 0 & 0 & 0 \\
0 & 0 & 0 & 0,90 & 0 & 0,10 & 0 & 0 & 0 & 0 & 0 \\
0 & 0 & 0 & 0 & 0,42 & 0 & 0,58 & 0 & 0 & 0 & 0 \\
0 & 0 & 0 & 0 & 0 & 0,88 & 0 & 0,12 & 0 & 0 & 0 \\
0 & 0 & 0 & 0 & 0 & 0 & 0,76 & 0 & 0,24 & 0 & 0 \\
0 & 0 & 0 & 0 & 0 & 0 & 0 & 0,83 & 0 & 0,17 & 0 \\
0 & 0 & 0 & 0 & 0 & 0 & 0 & 0 & 0,42 & 0 & 0,58 \\
0 & 0 & 0 & 0 & 0 & 0 & 0 & 0 & 0 & 1,00 & 0
\end{array}\right)
$$

(b) Ratos virtuais - rede fixa

$$
\mathrm{P}=\left(\begin{array}{ccccccccccc}
0 & 1,00 & 0 & 0 & 0 & 0 & 0 & 0 & 0 & 0 & 0 \\
0,05 & 0 & 0,95 & 0 & 0 & 0 & 0 & 0 & 0 & 0 & 0 \\
0 & 0,50 & 0 & 0,50 & 0 & 0 & 0 & 0 & 0 & 0 & 0 \\
0 & 0 & 0,34 & 0 & 0,66 & 0 & 0 & 0 & 0 & 0 & 0 \\
0 & 0 & 0 & 0,40 & 0 & 0,60 & 0 & 0 & 0 & 0 & 0 \\
0 & 0 & 0 & 0 & 0,24 & 0 & 0,76 & 0 & 0 & 0 & 0 \\
0 & 0 & 0 & 0 & 0 & 0,54 & 0 & 0,46 & 0 & 0 & 0 \\
0 & 0 & 0 & 0 & 0 & 0 & 0,53 & 0 & 0,47 & 0 & 0 \\
0 & 0 & 0 & 0 & 0 & 0 & 0 & 0,54 & 0 & 0,46 & 0 \\
0 & 0 & 0 & 0 & 0 & 0 & 0 & 0 & 0,63 & 0 & 0,37 \\
0 & 0 & 0 & 0 & 0 & 0 & 0 & 0 & 0 & 1,00 & 0
\end{array}\right)
$$

(c) Ratos virtuais - rede evolutiva

Figura 5.2: Matriz Markoviana de ratos controle (a) reais, (b) virtuais com rede fixa e (c) virtuais com rede evolutiva no LCE.

As matrizes estocásticas Markovianas experimentais e simuladas foram 
calculadas para uma melhor compreensão das transições entre as posições. Foram calculados também os vetores $\pi$ correspondentes a estas matrizes (como explicado no Capítulo 4). As matrizes são exibidas na Figura 5.2 e os vetores $\pi$, na Figura 5.3 .

Analisando essas matrizes concluímos que os ratos reais têm a tendência de se movimentar preferencialmente em direção ao centro do que à extremidade quando se encontra em um dos braços abertos. É possível observar esses fatos em cada linha da matriz, por exemplo na linha 2, na qual a probabilidade da transição da posição 2 para $3\left(p_{2,3}=65 \%\right)$ é maior do que a transição 2 para $1\left(p_{2,1}=35 \%\right)$, lembrando que a posição 1 representa a extremidade do braço aberto do labirinto reduzido. Contudo, o oposto acontece nos braços fechados, até que o rato chegue próximo à extremidade (nas posições 10 e 11 o rato segue geralmente para o centro).

Os ratos virtuais com redes fixas têm comportamento oposto ao dos ratos reais conforme suas matrizes Markovianas de transições. Por outro lado, os ratos virtuais com redes evolutivas tendem sempre a se deslocar para o centro, independentemente do braço onde se encontrem. No centro, tanto os ratos reais quanto virtuais preferencialmente vão para os braços fechados.

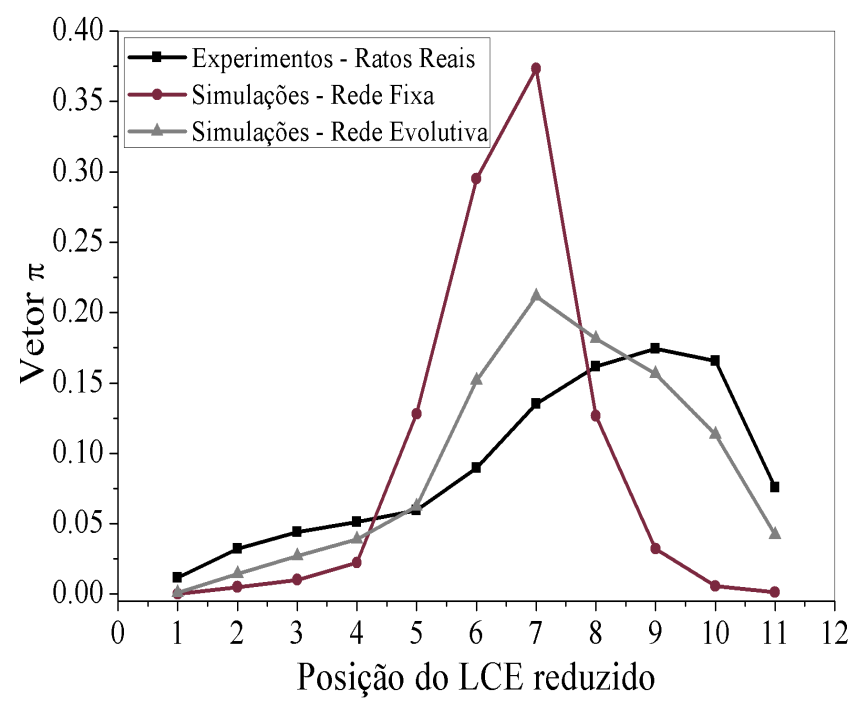

Figura 5.3: Vetor $\pi$ para ratos controle (a) reais, b) virtuais com rede fixa e (c) virtuais com rede evolutiva. As posições 1-5 correspondem aos braços abertos do labirinto, enquanto 7-11 correspondem aos braços fechados, e a posição 6 ao centro.

Os elementos dos vetores $\pi$ revelam as probabilidades de encontrar o rato virtual 
em cada posição do labirinto no estado estacionário. A Figura 5.3 mostra que no estado estacionário as probabilidades de os ratos virtuais com rede fixa se encontrarem nas primeiras posições de cada tipo de braço ou no centro (elementos 5,7 e 6 , respectivamente, do vetor $\pi$ ) são bem maiores do que dos ratos reais. As probabilidades de permanência do ratos virtuais com redes evolutivas são mais semelhantes às dos ratos virtuais, sendo um pouco mais frequentes as ocorrências no centro e nas primeiras posições dos braços fechados (elementos 6 e 7 do vetor $\pi$ ). Todas as demais posições possuem probabilidades levemente menores do que a dos ratos reais (exceto as primeiras posições dos braços abertos cujas probabilidades são praticamente idênticas às das mesmas posições dos ratos reais).

Tendo conseguido bons resultados para representar o rato controle, buscamos alterar os parâmetros da função de avaliação para reproduzir o comportamento de ratos sob efeito de drogas ansiogênicas e ansiolíticas. O mais interessante de nosso modelo é que podemos atribuir um único parâmetro ao efeito das drogas, bastando alterá-lo (sem modificar o valor dos demais parâmetros) para reproduzir o comportamento de ratos que receberam a injeção de uma droga. Esse aspecto é muito relevante do ponto de vista biológico, pois permite investigar a influência da droga no modelo proposto. O parâmetro em questão é o peso da punição, ou seja, o parâmetro $\beta$, que controla o quanto a exposição ao perigo inibe a exploração do animal.

$\mathrm{Na}$ sequência apresentamos simulações do comportamento de ratos submetidos à semicarbazida na concentração de $20 \mathrm{mg} / \mathrm{kg}$ (droga ansiogênica), comparados a dados de ratos reais (Figura 5.4). Conforme o teste Mann-Whitney, as distribuições de todas as variáveis dos ratos virtuais com redes evolutivas são estatisticamente equivalentes às distribuições dos ratos reais. Já o número de entradas nos braços fechados dos ratos virtuais com redes fixas não seguem a mesma distribuição que essas variáveis dos ratos reais.

As matrizes de transições e os vetores $\pi$ correspondentes aos dados exibidos na Figura 5.4 encontram-se nas Figuras 5.5 e 5.6. A matriz dos ratos reais sob efeito de droga semicarbazida $20 \mathrm{mg} / \mathrm{kg}$ mostra que nos braços fechados não possuem uma tendência geral de movimento: enquanto na posição adjacente ao centro se deslocam mais em direção à extremidade, nas demais posições preferem voltar ao centro, com 


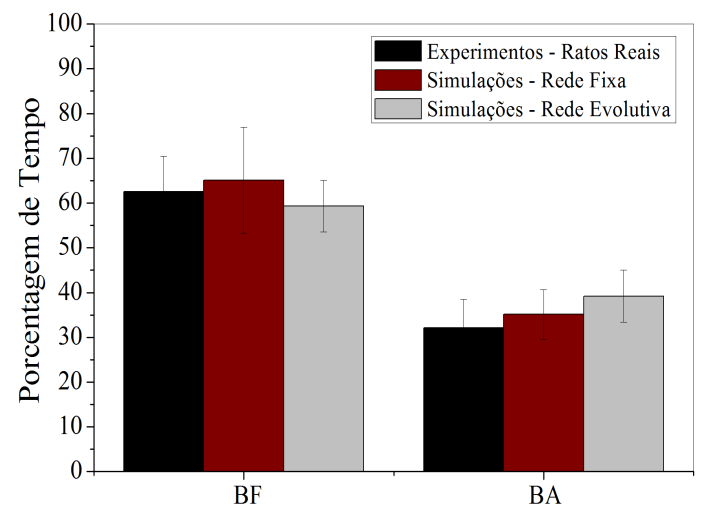

(a)

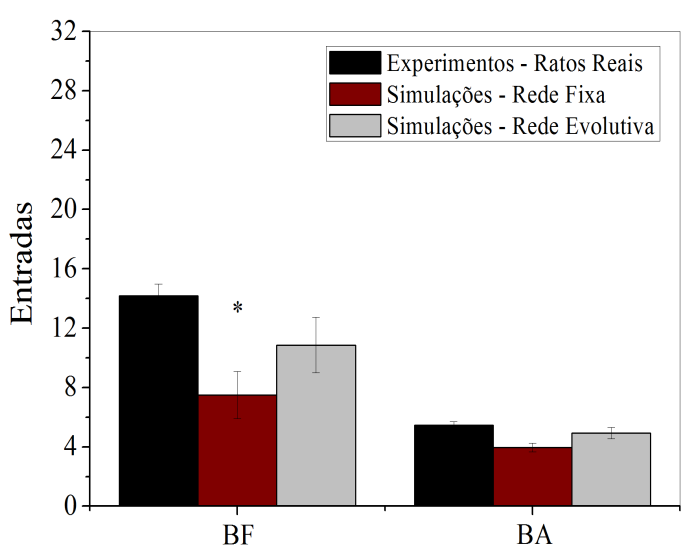

(c)

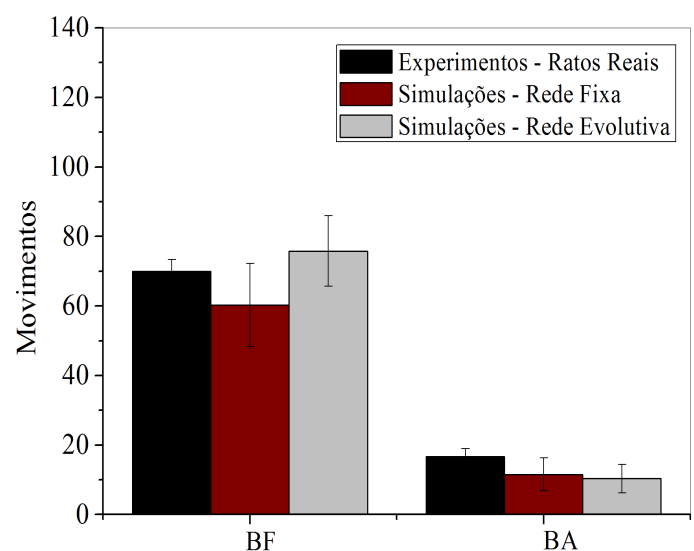

(b)

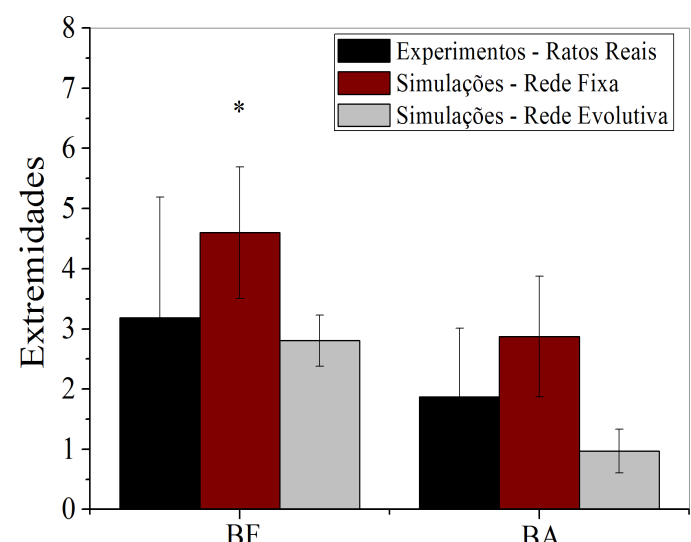

(d)

Figura 5.4: Média e erro padrão (a) do tempo de permanência nos braços abertos e fechados, (b) da quantidade de movimentos feitos em cada tipo de braço, (c) do número de entradas $e(d)$ chegadas às extremidades em cada tipo de braço para ratos reais $e$ virtuais sob efeito de semicarbazida $20 \mathrm{~m} / \mathrm{kg}$. O único parâmetro modificado em relação às simulações do rato controle é o $\beta$. Nestas simulações, $\beta=6,3$. O símbolo * indica que os resultados dos ratos reais e virtuais são de populações diferentes de acordo com o teste Mann-Whitney com nivel de significância 0,05.

exceção da posição 9, na qual parece não haver preferência alguma por parte dos roedores. Um fato importante é a elevada porcentagem de ocorrência de transições para os braços fechados a partir da região central do LCE $\left(p_{6,7}=90 \%\right)$, o que reflete nitidamente a grande ansiedade (medo) dos animais sob efeito de droga ansiogênica. Essa mesma ansiedade é vista nos ratos virtuais $\left(p_{6,7}=89 \%\right.$ para ratos com a rede fixa e $p_{6,7}=92 \%$ para aqueles com a rede evolutiva). 


$$
\mathrm{P}=\left(\begin{array}{ccccccccccc}
0 & 1,00 & 0 & 0 & 0 & 0 & 0 & 0 & 0 & 0 & 0 \\
0,32 & 0 & 0,68 & 0 & 0 & 0 & 0 & 0 & 0 & 0 & 0 \\
0 & 0,46 & 0 & 0,54 & 0 & 0 & 0 & 0 & 0 & 0 & 0 \\
0 & 0 & 0,45 & 0 & 0,55 & 0 & 0 & 0 & 0 & 0 & 0 \\
0 & 0 & 0 & 0,40 & 0 & 0,60 & 0 & 0 & 0 & 0 & 0 \\
0 & 0 & 0 & 0 & 0,10 & 0 & 0,90 & 0 & 0 & 0 & 0 \\
0 & 0 & 0 & 0 & 0 & 0,49 & 0 & 0,51 & 0 & 0 & 0 \\
0 & 0 & 0 & 0 & 0 & 0 & 0,52 & 0 & 0,48 & 0 & 0 \\
0 & 0 & 0 & 0 & 0 & 0 & 0 & 0,50 & 0 & 0,50 & 0 \\
0 & 0 & 0 & 0 & 0 & 0 & 0 & 0 & 0,75 & 0 & 0,25 \\
0 & 0 & 0 & 0 & 0 & 0 & 0 & 0 & 0 & 1,00 & 0
\end{array}\right)
$$

(a) Ratos reais

$$
\mathrm{P}=\left(\begin{array}{ccccccccccc}
0 & 1,00 & 0 & 0 & 0 & 0 & 0 & 0 & 0 & 0 & 0 \\
0,38 & 0 & 0,62 & 0 & 0 & 0 & 0 & 0 & 0 & 0 & 0 \\
0 & 0,47 & 0 & 0,53 & 0 & 0 & 0 & 0 & 0 & 0 & 0 \\
0 & 0 & 0,60 & 0 & 0,40 & 0 & 0 & 0 & 0 & 0 & 0 \\
0 & 0 & 0 & 0,51 & 0 & 0,49 & 0 & 0 & 0 & 0 & 0 \\
0 & 0 & 0 & 0 & 0,11 & 0 & 0,89 & 0 & 0 & 0 & 0 \\
0 & 0 & 0 & 0 & 0 & 0,52 & 0 & 0,48 & 0 & 0 & 0 \\
0 & 0 & 0 & 0 & 0 & 0 & 0,52 & 0 & 0,48 & 0 & 0 \\
0 & 0 & 0 & 0 & 0 & 0 & 0 & 0,53 & 0 & 0,47 & 0 \\
0 & 0 & 0 & 0 & 0 & 0 & 0 & 0 & 0,59 & 0 & 0,41 \\
0 & 0 & 0 & 0 & 0 & 0 & 0 & 0 & 0 & 1,00 & 0
\end{array}\right)
$$

(b) Ratos virtuais - rede fixa

$$
\mathrm{P}=\left(\begin{array}{ccccccccccc}
0 & 1,00 & 0 & 0 & 0 & 0 & 0 & 0 & 0 & 0 & 0 \\
0,45 & 0 & 0,55 & 0 & 0 & 0 & 0 & 0 & 0 & 0 & 0 \\
0 & 0,47 & 0 & 0,53 & 0 & 0 & 0 & 0 & 0 & 0 & 0 \\
0 & 0 & 0,45 & 0 & 0,55 & 0 & 0 & 0 & 0 & 0 & 0 \\
0 & 0 & 0 & 0,54 & 0 & 0,46 & 0 & 0 & 0 & 0 & 0 \\
0 & 0 & 0 & 0 & 0,08 & 0 & 0,92 & 0 & 0 & 0 & 0 \\
0 & 0 & 0 & 0 & 0 & 0,52 & 0 & 0,48 & 0 & 0 & 0 \\
0 & 0 & 0 & 0 & 0 & 0 & 0,52 & 0 & 0,48 & 0 & 0 \\
0 & 0 & 0 & 0 & 0 & 0 & 0 & 0,52 & 0 & 0,48 & 0 \\
0 & 0 & 0 & 0 & 0 & 0 & 0 & 0 & 0,64 & 0 & 0,36 \\
0 & 0 & 0 & 0 & 0 & 0 & 0 & 0 & 0 & 1,00 & 0
\end{array}\right)
$$

(c) Ratos virtuais - rede evolutiva

Figura 5.5: Matriz Markoviana de ratos (a) reais, (b) virtuais com rede fixa e (c) virtuais com rede evolutiva sob efeito de droga semicarbazida na concentração de $20 \mathrm{mg} / \mathrm{kg}$ no $L C E$.

Nota-se na Figura 5.6 que a probabilidade de encontrar os ratos reais nos braços abertos cresce quase linearmente da extremidade para o centro. Além disso, tanto os ratos reais quanto os virtuais de rede evolutiva têm uma elevada probabilidade de se encontrarem na posição 7 no regime estacionário. Assim como os reais, os ratos 


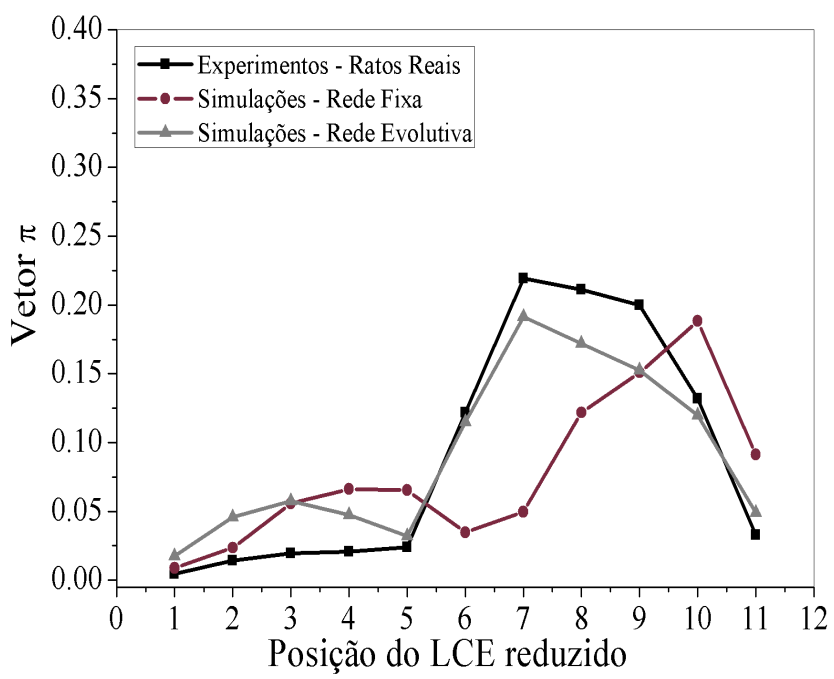

Figura 5.6: Vetor $\pi$ para ratos (a) reais reais sob efeito de semicarbazida $20 \mathrm{mg} / \mathrm{kg}$ e (b) virtuais com o parâmetro $\beta=2,2$. As posições 1-5 são os braços abertos do labirinto, 6-11 correspondem aos braços fechados e a posição 6, ao centro.

da rede evolutiva têm maior probabilidade de estar nas posições 7,8 e 9 . O vetor $\pi$ dos ratos evolutivos se assemelha mais ao dos ratos reais. Para os ratos virtuais com a rede fixa, a maior probabilidade de ocorrência acontece para a posição 10 do braço fechado (a posição adjacente à extremidade).

Também apresentamos aqui resultados de ratos que receberam injeção de clordiazepóxido $5 \mathrm{mg} / \mathrm{kg}$ (droga ansiolítica), na Figura 5.7, bem como as correspondentes simulações com redes neurais artificiais fixas e evolutivas. Novamente, as redes evolutivas forneceram melhores resultados dos que as redes fixas. O teste estatístico indica que as distribuições de todas as variáveis dos ratos evolutivos são semelhantes às distribuições das variáveis analisadas de ratos reais, exceto as entradas nos braços fechados. Os ratos virtuais de rede fixa também se saíram bem, com 5/8 das variáveis aprovadas no teste. As exceções foram as entradas nos braços fechados e abertos, bem como as chegadas às extremidades dos braços fechados, sendo tais variáveis significativamente menores para os ratos virtuais.

Na Figura 5.8 pode-se observar as matrizes correspondentes a estes dados. Os ratos reais (Figura 5.8(a)) se locomovem preferencialmente em direção às extremidades, com exceção de quando se encontram nas posições adjacentes a elas, quando tendem a voltar para as posições do meio do braço (se movem em direção 


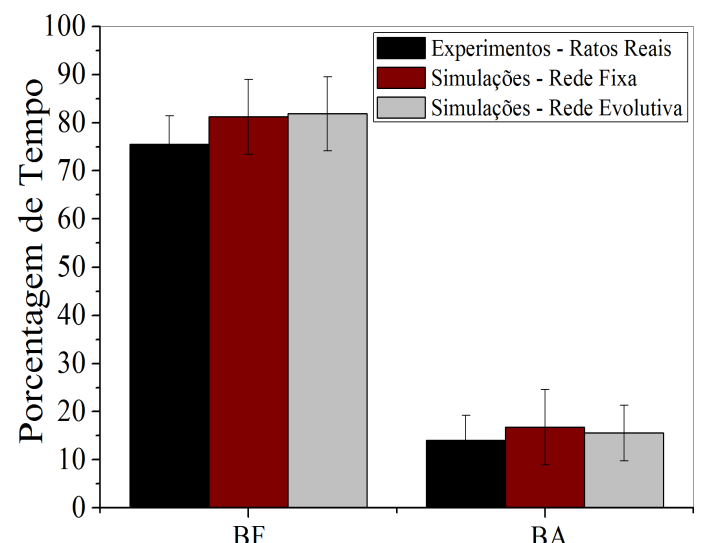

(a)

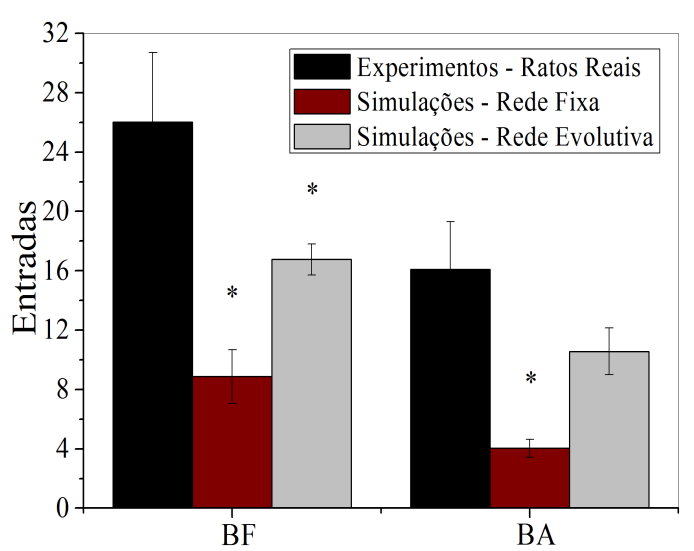

(c)

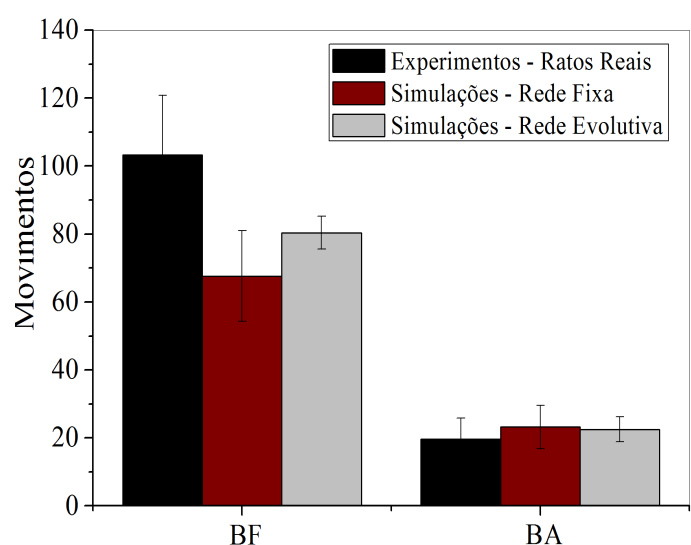

(b)

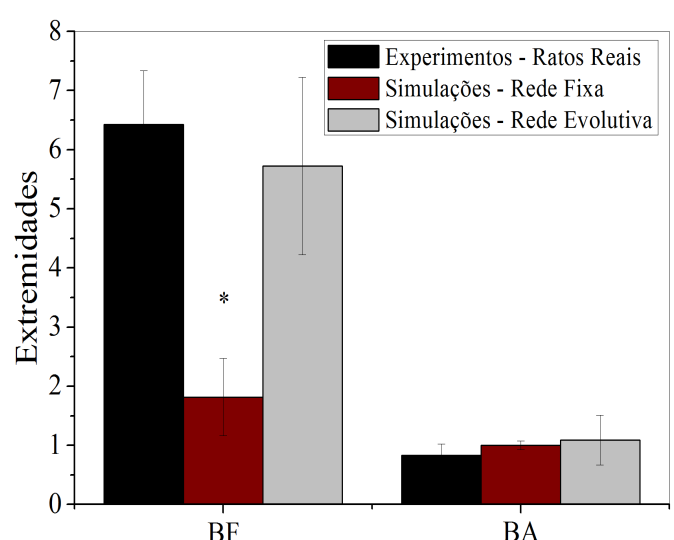

(d)

Figura 5.7: Média e erro padrão (a) do tempo de permanência nos braços abertos e fechados, (b) da quantidade de movimentos feitos em cada tipo de braço, (c) do número de entradas $e(d)$ chegadas às extremidades em cada tipo de braço para ratos reais $e$ virtuais sob efeito de clordiazepóxido $5 \mathrm{mg} / \mathrm{kg}$ em testes de cinco minutos no LCE. Nas simulações, $\beta=2,2$. O símbolo * indica que os resultados dos ratos reais e virtuais são de populações diferentes de acordo com o teste Mann-Whitney com nível de significância 0,05 .

ao centro).

O comportamento dos dois tipos de ratos virtuais estudados são semelhantes, de acordo com suas matrizes Markovianas ((Figura 5.8(b)),(c)). De modo geral, tendem a ir para o centro, exceto quando estão nos braços abertos nas posições imediatamente adjacentes à central (nesse caso preferem adentrar mais no braço do que ir para o centro).

Os vetores $\pi$ correspondentes às médias das trajetórias de ratos reais e virtuais 


$$
\mathrm{P}=\left(\begin{array}{ccccccccccc}
0 & 1,00 & 0 & 0 & 0 & 0 & 0 & 0 & 0 & 0 & 0 \\
0,46 & 0 & 0,54 & 0 & 0 & 0 & 0 & 0 & 0 & 0 & 0 \\
0 & 0,50 & 0 & 0,50 & 0 & 0 & 0 & 0 & 0 & 0 & 0 \\
0 & 0 & 0,51 & 0 & 0,49 & 0 & 0 & 0 & 0 & 0 & 0 \\
0 & 0 & 0 & 0,51 & 0 & 0,49 & 0 & 0 & 0 & 0 & 0 \\
0 & 0 & 0 & 0 & 0,48 & 0 & 0,52 & 0 & 0 & 0 & 0 \\
0 & 0 & 0 & 0 & 0 & 0,48 & 0 & 0,52 & 0 & 0 & 0 \\
0 & 0 & 0 & 0 & 0 & 0 & 0,49 & 0 & 0,51 & 0 & 0 \\
0 & 0 & 0 & 0 & 0 & 0 & 0 & 0,49 & 0 & 0,51 & 0 \\
0 & 0 & 0 & 0 & 0 & 0 & 0 & 0 & 0,56 & 0 & 0,44 \\
0 & 0 & 0 & 0 & 0 & 0 & 0 & 0 & 0 & 1,00 & 0
\end{array}\right)
$$

(a) Ratos reais

$$
\mathrm{P}=\left(\begin{array}{ccccccccccc}
0 & 1,00 & 0 & 0 & 0 & 0 & 0 & 0 & 0 & 0 & 0 \\
0,50 & 0 & 0,50 & 0 & 0 & 0 & 0 & 0 & 0 & 0 & 0 \\
0 & 0,49 & 0 & 0,51 & 0 & 0 & 0 & 0 & 0 & 0 & 0 \\
0 & 0 & 0,43 & 0 & 0,57 & 0 & 0 & 0 & 0 & 0 & 0 \\
0 & 0 & 0 & 0,56 & 0 & 0,44 & 0 & 0 & 0 & 0 & 0 \\
0 & 0 & 0 & 0 & 0,16 & 0 & 0,84 & 0 & 0 & 0 & 0 \\
0 & 0 & 0 & 0 & 0 & 0,51 & 0 & 0,49 & 0 & 0 & 0 \\
0 & 0 & 0 & 0 & 0 & 0 & 0,52 & 0 & 0,48 & 0 & 0 \\
0 & 0 & 0 & 0 & 0 & 0 & 0 & 0,56 & 0 & 0,44 & 0 \\
0 & 0 & 0 & 0 & 0 & 0 & 0 & 0 & 0,62 & 0 & 0,38 \\
0 & 0 & 0 & 0 & 0 & 0 & 0 & 0 & 0 & 1,00 & 0
\end{array}\right)
$$

(b) Ratos virtuais - rede fixa

$$
\mathrm{P}=\left(\begin{array}{ccccccccccc}
0 & 1,00 & 0 & 0 & 0 & 0 & 0 & 0 & 0 & 0 & 0 \\
0,33 & 0 & 0,67 & 0 & 0 & 0 & 0 & 0 & 0 & 0 & 0 \\
0 & 0,40 & 0 & 0,60 & 0 & 0 & 0 & 0 & 0 & 0 & 0 \\
0 & 0 & 0,37 & 0 & 0,63 & 0 & 0 & 0 & 0 & 0 & 0 \\
0 & 0 & 0 & 0,52 & 0 & 0,48 & 0 & 0 & 0 & 0 & 0 \\
0 & 0 & 0 & 0 & 0,35 & 0 & 0,65 & 0 & 0 & 0 & 0 \\
0 & 0 & 0 & 0 & 0 & 0,51 & 0 & 0,49 & 0 & 0 & 0 \\
0 & 0 & 0 & 0 & 0 & 0 & 0,60 & 0 & 0,40 & 0 & 0 \\
0 & 0 & 0 & 0 & 0 & 0 & 0 & 0,56 & 0 & 0,44 & 0 \\
0 & 0 & 0 & 0 & 0 & 0 & 0 & 0 & 0,59 & 0 & 0,41 \\
0 & 0 & 0 & 0 & 0 & 0 & 0 & 0 & 0 & 1,00 & 0
\end{array}\right)
$$

(c) Ratos virtuais - rede evolutiva

Figura 5.8: Matriz Markoviana de ratos (a) reais, (b) virtuais com rede fixa e (c) virtuais com rede evolutiva sob efeito de droga ansiolitica clordiazepóxido na concentração de 5 $\mathrm{mg} / \mathrm{kg}$ no LCE,

sob efeito de clordiazepóxido $5 \mathrm{mg} / \mathrm{kg}$ constam na Figura 5.9. As probabilidades de encontrar os ratos reais nos braços abertos e fechados são praticamente simétricas, diminuindo nas extremidades. O oposto acontece com os ratos virtuais com rede fixa: as probabilidades de se localizarem nas extremidades são elevadas, maiores 
do que para todas as outras posições do LCE. Os ratos virtuais de rede evolutiva possuem praticamente idêntica probabilidade de permanência nas posições $4,5,9$, 10 e 11 que os ratos reais. A posição 7 (adjacente à central, no braço fechado) é a mais provável para os ratos de rede evolutiva.

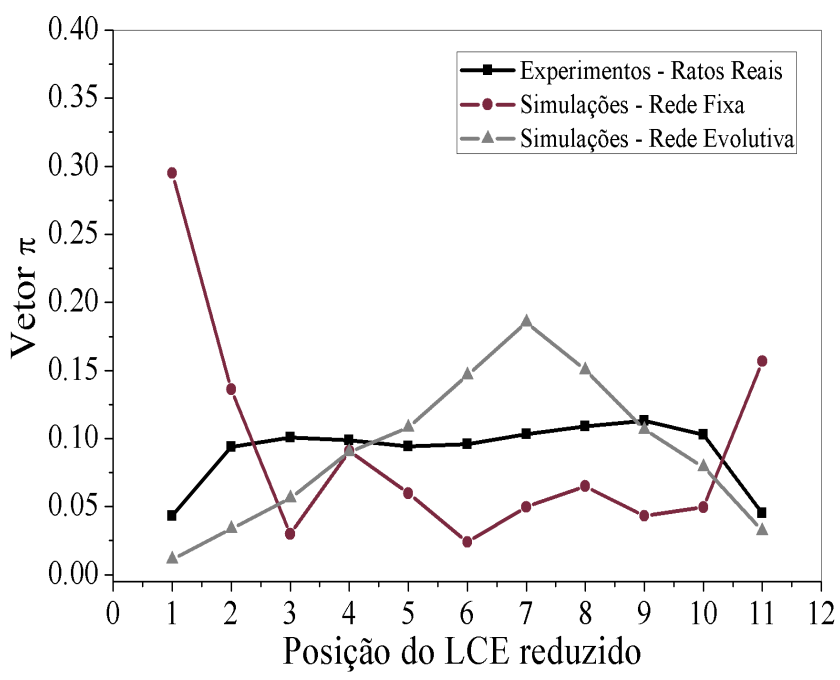

Figura 5.9: Vetor $\pi$ para ratos (a) reais sob efeito de clordiazepóxido $5 \mathrm{mg} / \mathrm{kg}$ e (b) virtuais com o parâmetro $\beta=6,0$. As posições 1-5 são os braços abertos do labirinto, 6-11 correspondem aos braços fechados e a posição 6 ao centro.

Dados os resultados apresentados anteriormente fica claro que os melhores foram obtidos com ratos virtuais com redes evolutivas (ressaltando que 21 das 24 variáveis estudadas, ou seja, 87,5\%, dos ratos desse modelo foram aprovadas no teste Mann-Whitney, contra 13/24, ou seja, 54,2\%, dos ratos virtuais de rede fixa). Isso deve ocorrer porque apenas os sensores e neurônios mais úteis/necessários para o agente virtual são mantidos neste modelo. Sendo assim, os demais resultados deste e do próximo capítulo serão focados neste modelo (ratos virtuais com redes evolutivas).

Para estudarmos mais a fundo o efeito do parâmetro $\beta$ no comportamento do rato virtual, a Figura 5.10 mostra as variáveis consideradas mais importantes para a análise da ansiedade do roedor no LCE (tempo de permanência e número de entrada nos braços abertos e fechados) em função de $\beta$. Os resultados dos agentes evolutivos podem ser comparados aos resultados obtidos em experimentos com ratos reais, contidos nos insets das figuras. Os resultados dos experimentos com ratos reais 
correspondem a roedores sob efeito de droga ansiogênica (SCZ) nas concentrações de 20, 40 e $80 \mathrm{mg} / \mathrm{kg}$, droga ansiolítica (CDP) na concentração de $5 \mathrm{mg} / \mathrm{kg}$, e ratos controle (CTRL). Para os ratos virtuais, 30 execuções do AG foram realizadas para cada valor inteiro de $\beta$ entre 1 e 10 .
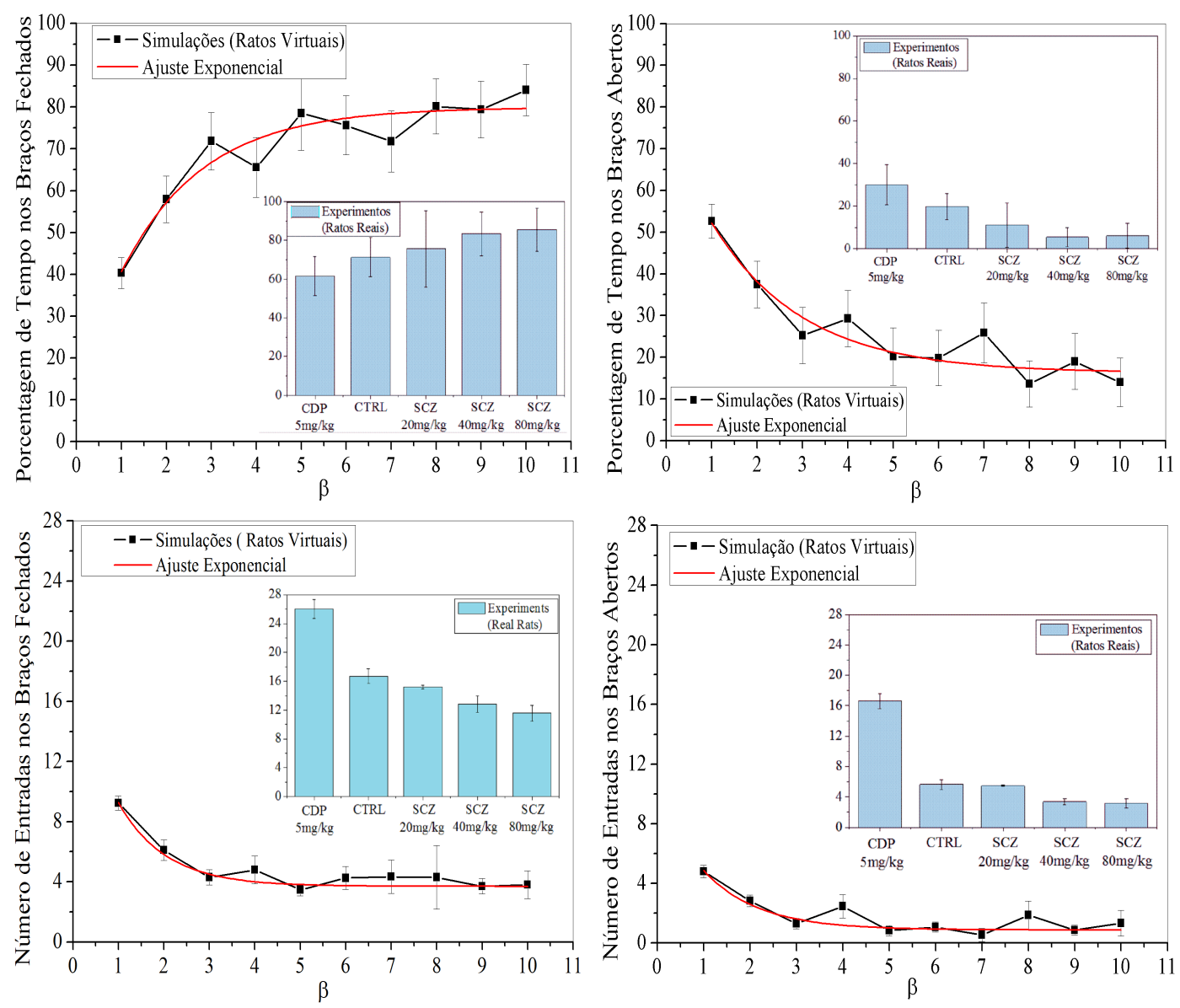

Figura 5.10: Dependência do tempo gasto nos braços (a) fechados e (b) abertos, e a frequência de entradas nos braços (c) fechados e (d) abertos dos ratos virtuais devido à veriação de $\beta$. Os "insets" mostram o valor das mesmas variáveis para ratos reais controles (CTRL) e sob efeito de droga semicarbazida (SCZ) na concentração de 20, 40 e $80 \mathrm{mg} / \mathrm{kg}$, e clordiazepóxido (CDP) de $5 \mathrm{mg} / \mathrm{kg}$.

As curvas de dependência para ratos reais e virtuais são bem ajustadas por curvas exponenciais cujos parâmetros são exibidos na Tabela 5.1. A porcentagem de tempo gasto nos braços abertos cresce exponencialmente com o aumento da dosagem de droga ansiogênica nos ratos reais e com o aumento de $\beta$ nos ratos virtuais. Por outro lado, o tempo de permanência nos braços abertos a frequência de entradas em ambos tipos de braços decaem exponencialmente com o aumento da dosagem ansiogênica e 


\begin{tabular}{|c|c|c|c|c|c|c|c|}
\hline \multicolumn{8}{|c|}{ Equação $y=A e^{-x / t}+y_{0}$} \\
\hline \multirow{2}{*}{ Influência } & \multirow{2}{*}{ Variável } & \multicolumn{2}{|c|}{$y_{0}$} & \multicolumn{2}{|c|}{$A$} & \multicolumn{2}{|c|}{$t$} \\
\hline & & Média & EP & Média & EP & Média & EP \\
\hline \multirow{4}{*}{ (Ratos reais) } & Tempo nos braços fechados & 84,92 & 12,91 & $-69,67$ & 9,60 & 4,10 & 2,24 \\
\hline & Tempo nos braços aberto & 12,35 & 12,15 & 69,02 & 9,93 & 3,98 & 2,25 \\
\hline & Entradas nos braços fechados & 9,60 & 3,17 & 7,23 & 3,01 & 58,45 & 46,96 \\
\hline & Entradas nos braços abertos & 0,34 & 1,1 & 8,7 & 1,13 & 3,65 & 1,76 \\
\hline \multirow{4}{*}{ (Ratos virtuais) } & Tempo nos braços fechados & 79,91 & 2,50 & $-67,81$ & 9,36 & 1,82 & 0,46 \\
\hline & Tempo nos braços abertos & 16,22 & 2,53 & 59,08 & 8,31 & 2,02 & 0,55 \\
\hline & Entradas nos braços fechados & 3,98 & 0,19 & 10,84 & 2,62 & 1,14 & 0,27 \\
\hline & Entradas nos braços abertos & 0,88 & 0,19 & 9,22 & 2,22 & 1,19 & 0,29 \\
\hline
\end{tabular}

Tabela 5.1: Média e erro padrão (EP) dos parâmetros das curvas de ajustes exponenciais contidas na Figura 5.10. Na equação dos ratos reais, $x$ corresponde à dosagem da droga, enquanto que $x=\beta$ para os ratos virtuais.

do parâmetro $\beta$. O comportamento de todas as variáveis analisadas de ratos virtuais em função das drogas ansiogênicas/ansiolíticas correspondem qualitativamente ao comportamento de ratos reais.

Os resultados apresentados neste capítulo sugerem que o modelo proposto contém as características mais relevantes envolvidas no comportamento exploratório do rato no labirinto em cruz elevado. Isso foi possível pelo uso de uma função de avaliação que resume o conflito medo/exploração de ratos [2]. Um fator de equilíbrio entre a recompensa e a punição parece ser uma eficiente maneira de simular as diferenças no comportamento de ratos sob influência de drogas ansiogênicas e ansiolíticas. Esse fator, representado pelo parâmetro $\beta$, permite a reprodução dos estímulos de curiosidade e vontade de exploração, e as sensações opostas causadas pelo medo. $\mathrm{O}$ decréscimo de $\beta$ implica em um aumento no impulso exploratório, enquanto que um acréscimo nesse parâmetro resulta em mais medo de explorar o labirinto.

Os conjuntos de parâmetros usados nas simulações nos habilitou a reproduzir o comportamento médio de ratos controle e ratos sob efeito de diferentes dosagens de droga ansiogênicas (semicarbazida) e droga ansiolítica (clordiazepóxido). Como não possuímos dados exaustivos de ratos sob efeito de uma vasta gama de drogas e dosagens ansiolíticas e ansiogênicas, não podemos afirmar que esse conjunto de 
parâmetros seja válido para todas as drogas e dosagens; provavelmente não é. Contudo, variando outros parâmetros deve ser possível reproduzir o efeito de uma maior variedade drogas. 


\section{Capítulo}

\section{Resultados: redes neurais artificiais e trajetórias no LCE}

Como mencionado no capítulo anterior, neste capítulo apresentaremos dados apenas dos ratos controle virtuais com rede evolutiva, devido aos melhores resultados obtidos nas simulações. Estudaremos aqui as arquiteturas das redes neurais artificiais dos ratos virtuais obtidos com esse modelo, bem como suas trajetórias no LCE. Com este estudo, buscamos entender o processo de tomada de decisão do rato virtual para, assim, adquirirmos um possível melhor entendimento do processo de tomada de decisão dos ratos reais no LCE. A primeira seção deste capítulo (Seção 6.1) contém análises das RNAs (ratos virtuais) evoluídas pelo AG nas simulações. Na Seção 6.2, as trajetórias de ratos reais e virtuais são estudadas. Por fim, na Seção 6.3 o papel de cada neurônio no comportamento de dois diferentes ratos virtuais é investigado.

\subsection{Arquiteturas das redes neurais artificiais}

No capítulo 4 foi explicado que cada rato virtual pode ter, no máximo, 6 sensores e 4 neurônios ocultos. Analisando 30 execuções completas do algoritmo genético com $\beta=3,2$ (isto é, ratos virtuais com comportamento semelhante ao de ratos controle reais), vemos que o numero médio de sensores dos ratos virtuais oscila ao longo das gerações em torno de 3,0 e a média dos neurônios ocultos, em torno de 2,0, como mostra a Figura 6.1. Assim, notamos, aparentemente, que devido à grande variabilidade de ratos virtuais ao longo da simulação, a arquitetura média dos ratos 
virtuais a cada geração se assemelha a uma arquitetura aleatória média.

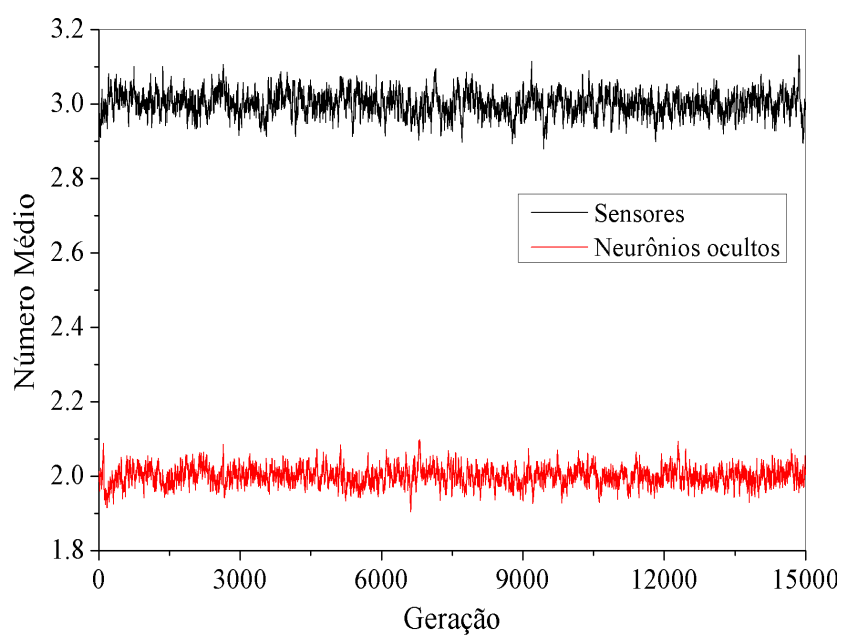

Figura 6.1: Evolução da média de sensores e neurônios intermediários de toda a população de 30 execuções ao longo das 15.000 gerações dos ratos controle virtuais com redes evolutivas.

Se considerarmos apenas o melhor indivíduo obtido em cada uma das 30 execuções, vemos que possuem, em média, 3,07 sensores e 2,43 neurônios ocultos. Deste modo, os ratos virtuais mais aptos têm em média mais neurônios ocultos do que a média aleatória $(2,00)$ e número de sensores similares à média, ou seja, 3,00 sensores. A Tabela 6.1 mostra quantos dos melhores ratos virtuais (isto é, do conjunto contendo o melhor indivíduo de cada execução) possuem cada quantidade de sensores possível conforme o modelo (de 1 a 6 sensores). Vemos que os números predominantes de sensores são três ou quatro na camada de entrada; os ratos com essa quantidade de sensores totalizam $60 \%$ dos ratos virtuais. Nenhum dos 30 melhores ratos possuem seis sensores e apenas três deles (10\%) têm cinco sensores. Isso indica que não é necessário um grande número de sensores para o rato virtual percorrer o LCE. 


\begin{tabular}{|c|c|c|}
\hline $\begin{array}{c}\text { Número de } \\
\text { sensores }\end{array}$ & $\begin{array}{c}\text { Quantidade de } \\
\text { ratos virtuais }\end{array}$ & $\begin{array}{c}\text { Porcentagem de } \\
\text { ratos virtuais }\end{array}$ \\
\hline \hline 1 & 3 & 10,00 \\
2 & 6 & 20,00 \\
3 & 9 & 30,00 \\
4 & 9 & 30,00 \\
5 & 3 & 10,00 \\
6 & 0 & 0,00 \\
\hline
\end{tabular}

Tabela 6.1: Quantidade e porcentagem dos melhores ratos virtuais com 1, 2, 3, 4, 5 ou 6 sensores na arquitetura de suas RNAs.

A Tabela 6.2 contém as especificações dos sensores dos 30 melhores ratos virtuais selecionados pelo AG. A maioria deles combina sensores tanto de curta quanto de longa distância, como mostra a tabela. Observa-se que a combinação de sensores mais prevalentes são: dois sensores de curta distância com um sensor de longa distância $(2 \mathrm{C}$ e $1 \mathrm{~L})$ ou dois sensores de curta e longa distância (2C e $2 \mathrm{~L})$, sendo cinco ratos virtuais de cada tipo $(16,67 \%)$. Salienta-se que a diferença entre as duas combinações é apenas a utilização de um ou dois sensores de longa distância, ambas com dois sensores de curta distância. Outras boas combinações de sensores envolvem um sensor de longa distância com um de curta distância (1C e 1L), um sensor de longa distância com três de curta distância (3C e 1L), ou um único sensor de curta distância (1C) - cada uma dessas arquiteturas equivale a 10\% dos ratos virtuais.

A Tabela 6.2 contém apenas as combinações de existentes entre os 30 melhores indivíduos das simulações. Deste modo, nota-se que algumas combinações de sensores não representam nenhum dos melhores ratos virtuais: $3 \mathrm{C}$; $3 \mathrm{~L}$ e $3 \mathrm{C}$. Arquiteturas com sensores 1C e 3L, 2C, 3C e 2L, 1L correspondem respectivamente a apenas um de cada dos 30 melhores ratos virtuais analisados (3,33\%). Apenas três dos ratos virtuais não possuem nenhum sensor de longa distância, enquanto cinco deles não possuem sensores de curta distância. Vemos que as combinações de sensores utilizadas pelos agentes são bastante variáveis, mas algumas delas se repetem duas vezes: (DC), (EC, FC, EL), (FC, DC, DL), (EC, FC, DC, DL), (EL, 
FL, DL). A combinação predominante é: (EC, FC, EL, FL), a qual corresponde a três dos melhores ratos virtuais. Como 21 dos 30 ratos (70\%) combinam sensores de curta e longa distância, vemos que ambos os tipos de localização são importantes para os ratos virtuais. No entanto, vale ressaltar que várias combinações são utilizadas. Permite-se, portanto, afirmar que estratégias diferentes de tomada de decisão geram comportamentos semelhantes aos dos ratos virtuais.

Nos ratos reais, podemos associar os sensores de curta distância a vibrissas ${ }^{1}$ do animal, que possuem função tátil e auxiliam na percepção do movimento, especialmente em condições de baixa visibilidade. Também podemos associar tais sensores à visão de curta distância. Já os sensores de longa distância podem ser interpretados como a capacidade de visão a distâncias mais longas dos olhos dos roedores, que captam estímulos visuais. Sabemos que tanto os estímulos vindos das vibrissas quantos dos olhos são utilizados para locomoção do rato, no entanto os olhos são prevalentes, inclusive no comportamento desempenhado pelo rato no labirinto (conflito medo/curiosidade) [10, 74]. Vemos também uma leve prevalência dos sensores de longa distância nos ratos virtuais: apenas três deles não possuem sensores de longa distância, enquanto seis não têm nenhum sensor de curta distância.

Como sintetiza a Tabela 6.3, a maior parte dos ratos virtuais possui três neurônios na camada intermediária $(36,67 \%)$. No entanto, apenas um rato possui um neurônio nessa camada, o que indica que a presença de um único neurônio intermediário pode não ser ideal para o rato virtual. Refletindo sobre isso, pode-se compreender o por quê: se pensarmos em uma tarefa de classificação, cada neurônio da camada intermediária é reponsável por gerar um único hiperplano para a separação das regiões de decisão. Um único hiperplano é ideal para problemas linearmente separáveis, mas insuficiente para problemas de decisão não linearmente separáveis. Vale salientar que este rato virtual obteve o menor valor de aptidão dentre os melhores ratos de cada execução do programa (lembrando que a avaliação do rato depende de uma função de fitness probabilística, o que faz com que um mesmo rato possa ser avaliado mais positivamente ou mais negativamente a cada geração; assim,

\footnotetext{
${ }^{1}$ Prolongamentos de pelos queratinosos (nos mamíferos) e plumas (nos pássaros) na região do vestíbulo nasal. São órgãos sensoriais próprios de certos animais, principalmente dos mamíferos (dentre esses há a exceção dos golfinhos, por exemplo). É comum nos referirmos às vibrissas de felinos e roedores como "bigodes".
} 


\begin{tabular}{|c|c|c|c|c|}
\hline $\begin{array}{l}\text { Tipos de } \\
\text { sensores }\end{array}$ & $\begin{array}{l}\text { Quantidade de } \\
\text { ratos virtuais }\end{array}$ & $\begin{array}{c}\text { Porcentagem } \\
\text { de ratos virtuais }\end{array}$ & Sensores & $\begin{array}{c}\text { Quantidade } \\
\text { de neurônios }\end{array}$ \\
\hline $1 \mathrm{C}$ & 2 & 6,67 & $\begin{array}{l}\mathrm{DC} \\
\mathrm{DC}\end{array}$ & $\begin{array}{l}{ }^{*} 3^{*} \\
4\end{array}$ \\
\hline $1 \mathrm{C}$ e $1 \mathrm{~L}$ & 3 & 10 & $\begin{array}{l}\mathrm{FC}, \mathrm{FL} \\
\mathrm{EC}, \mathrm{DL} \\
\mathrm{EC}, \mathrm{EL}\end{array}$ & $\begin{array}{l}4 \\
2 \\
3\end{array}$ \\
\hline $1 \mathrm{C}$ e $2 \mathrm{~L}$ & 2 & 6,67 & $\begin{array}{l}\mathrm{DC}, \mathrm{EL}, \mathrm{DL} \\
\mathrm{DC}, \mathrm{FL}, \mathrm{DL}\end{array}$ & $\begin{array}{l}2 \\
4\end{array}$ \\
\hline $1 \mathrm{C}$ e $3 \mathrm{~L}$ & 1 & 3,33 & FD, EL, FL, DL & 3 \\
\hline $2 \mathrm{C}$ & 1 & 3,33 & $\mathrm{EC}, \mathrm{FC}$ & 2 \\
\hline $2 \mathrm{C}$ e $1 \mathrm{~L}$ & 5 & 16,67 & $\begin{array}{l}\mathrm{EC}, \mathrm{FC}, \mathrm{EL} \\
\mathrm{EC}, \mathrm{FC}, \mathrm{EL} \\
\mathrm{FC}, \mathrm{DC}, \mathrm{DL} \\
\mathrm{EC}, \mathrm{DC}, \mathrm{DL} \\
\mathrm{FC}, \mathrm{DC}, \mathrm{DL}\end{array}$ & $\begin{array}{c}3 \\
2 \\
2 \\
2 \\
{ }^{*} 3^{*}\end{array}$ \\
\hline $2 \mathrm{C}$ e $2 \mathrm{~L}$ & 5 & 16,67 & $\begin{array}{l}\text { EC, DC, FL, DL } \\
\text { EC, FC, EL, FL } \\
\text { EC, FC, EL, FL } \\
\text { EC, DC, FL, DL } \\
\text { EC, FC, EL, FL }\end{array}$ & $\begin{array}{l}2 \\
2 \\
2 \\
3 \\
3 \\
\end{array}$ \\
\hline $2 \mathrm{C}$ e $3 \mathrm{~L}$ & 2 & 6,67 & $\begin{array}{l}\mathrm{EC}, \mathrm{FC}, \mathrm{EL}, \mathrm{FL}, \mathrm{DL} \\
\mathrm{EC}, \mathrm{DC}, \mathrm{EL}, \mathrm{FL}, \mathrm{DL}\end{array}$ & $\begin{array}{l}2 \\
2 \\
\end{array}$ \\
\hline $3 \mathrm{C} \mathrm{E} 1 \mathrm{~L}$ & 3 & 10 & $\begin{array}{l}\mathrm{EC}, \mathrm{FC}, \mathrm{DC}, \mathrm{DL} \\
\mathrm{EC}, \mathrm{FC}, \mathrm{DC}, \mathrm{DL} \\
\mathrm{EC}, \mathrm{FC}, \mathrm{DC}, \mathrm{EL}\end{array}$ & $\begin{array}{c}4 \\
4 \\
* 3^{*} \\
\end{array}$ \\
\hline $3 \mathrm{C}$ e $2 \mathrm{~L}$ & 1 & 3,33 & $\mathrm{EC}, \mathrm{FC}, \mathrm{DC}, \mathrm{EL}, \mathrm{FL}$ & 4 \\
\hline $1 \mathrm{~L}$ & 1 & 3,33 & FL & 3 \\
\hline $2 \mathrm{~L}$ & 2 & 6,67 & $\begin{array}{l}\text { EL, DL } \\
\text { EL, FL }\end{array}$ & $\begin{array}{l}1 \\
3 \\
\end{array}$ \\
\hline $3 \mathrm{~L}$ & 2 & 6,67 & $\begin{array}{l}\text { EL, FL, DL } \\
\text { EL, FL, DL }\end{array}$ & $\begin{array}{l}2 \\
4\end{array}$ \\
\hline
\end{tabular}

Tabela 6.2: Combinações dos sensores dos melhores agentes (ratos) virtuais das 30 execuções do AG. Na tabela, "L" significa "Longa distância" e "C", "Curta distância". A quantidade e a porcentagem de ratos com cada combinação de sensores são apresentadas, assim como o número de neurônios intermediários de cada um dos ratos virtuais. Os símbolos ${ }^{* *}$ indicam os três ratos virtuais com maior fitness calculado. 
mesmo ratos "ruins" podem ocasionalmente evoluir no algoritmo genético).

\begin{tabular}{|c|c|c|}
\hline $\begin{array}{c}\text { Número de } \\
\text { neurônios }\end{array}$ & $\begin{array}{c}\text { Quantidade de } \\
\text { ratos virtuais }\end{array}$ & $\begin{array}{c}\text { Porcentagem de } \\
\text { ratos virtuais }\end{array}$ \\
\hline \hline 1 & 1 & 3,33 \\
2 & 9 & 30,00 \\
3 & 11 & 36,67 \\
4 & 9 & 30,00 \\
\hline
\end{tabular}

Tabela 6.3: Quantidade e porcentagem de neurônios na camada oculta dos 30 ratos virtuais (cada um correspondendo ao melhor rato de uma execução do $A G$ ).

Os melhores resultados foram obtidos com dois, três ou quatro neurônios, pois um maior número neurônios gera uma melhor separação do espaço de decisão, o que permite a tomada de decisões mais complexas. Além disso, mais valores de memória (recorrências) são utilizados, o que permite utilizar informações de estados passados de forma mais complexa. Por outro lado, mais neurônios implicam em mais pesos para serem otimizados, e portanto maior dificuldade de treinamento, o que explica por que nem sempre mais neurônios resultam em melhores resultados.

\subsection{Trajetórias no LCE real e virtual}

Nesta seção analisaremos as trajetórias de ratos controle reais e virtuais no LCE. Verificando as trajetórias dos 30 ratos virtuais mais bem avaliados conforme a equação de fitness (Eq. 4.3) durante as execuções do algoritmo genético, constatamos a existência de determinados comportamentos desempenhados por grupos de ratos virtuais:

- Parado: o rato virtual fica estático em uma posição, orientado para a mesma direção em que estacionou;

- Girando na mesma posição: o rato não troca de posição, mas gira $90^{\circ}$ no mesmo sentido a cada passo de tempo; 
- Periódico: o agente virtual desempenha uma trajetória periódica no labirinto virtual.

- Estratégia que se repete: embora a trajetória do rato não seja periódica, o agente adota um mesmo comportamento (estratégia) ao longo da trajetória;

- Combinação de estratégias: um tipo de estratégia (comportamento) é utilizado para deslocamento no LCE por um período de passos de tempo. Depois, a estratégia é alterada;

- Variável: não é possível verificar nenhuma estratégia dominante no trajeto desempenhado pelo rato virtual no labirinto.

Vale salientar que em muitos casos há um curto período transiente até que o rato desenvolva um dos comportamentos mencionados acima. Na Figura 6.2(a) apresentamos o LCE utilizado para análise das trajetórias dos ratos nos gráficos seguintes. Um braço fechado corresponde às posições 1 a 5 do LCE virtual e o braço fechado oposto vai de -1 a -5 . Similarmente, os braços abertos são representados pelas posições 6 a 10 e -6 a -10. A posição 0 é a central. As orientações do rato virtual no LCE são ilustradas na Figura 6.2(b).

A Figura 6.3 contém um exemplo de trajetória de um rato virtual que adota o comportamento de permanecer parado no labirinto. Essa trajetória é exibida em um gráfico (Figura 6.3(a)), mas também em um esquema ilustrativo do labirinto (Figura 6.3(b)). Nota-se que o gráfico de baixo corresponde aos deslocamentos do rato no labirinto, às posições que ele percorre, enquanto o gráfico superior contém as direções (orientações) do rato a cada passo computacional. Observa-se que após 30 iterações o rato fica parado até o final de seu experimento no labirinto.

Um exemplo de cada tipo de comportamento pode ser observado na Figura 6.4. Cada subfigura corresponde à trajetória de um dos melhores ratos virtuais das 30 execuções do algoritmo genético. Na Figura 6.4(a), o rato se move até a iteração 46, quando fica parado na terceira posição de um braço fechado. Embora não mude de posição, gira constantemente em sentido horário (como mostra o gráfico superior). A Figura 6.4(b) mostra um rato um rato com trajetória periódica após 36 iterações. 


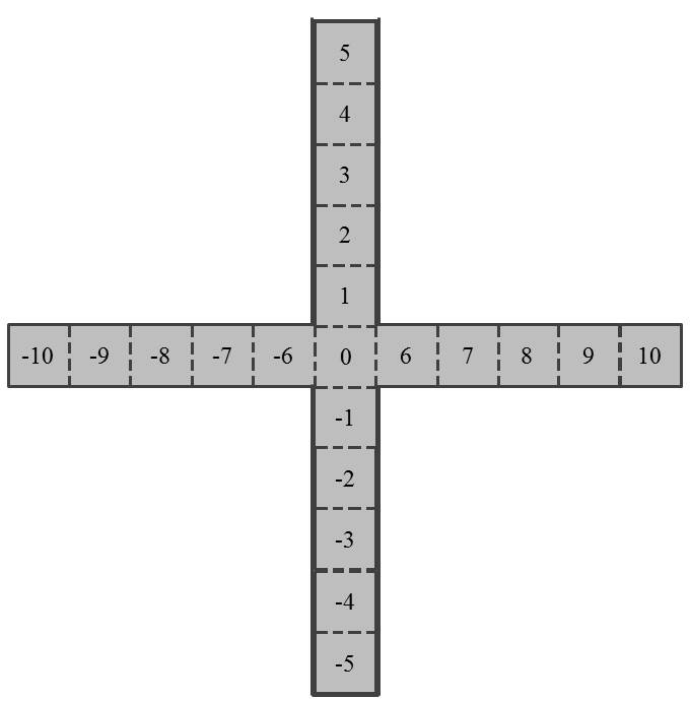

(a)

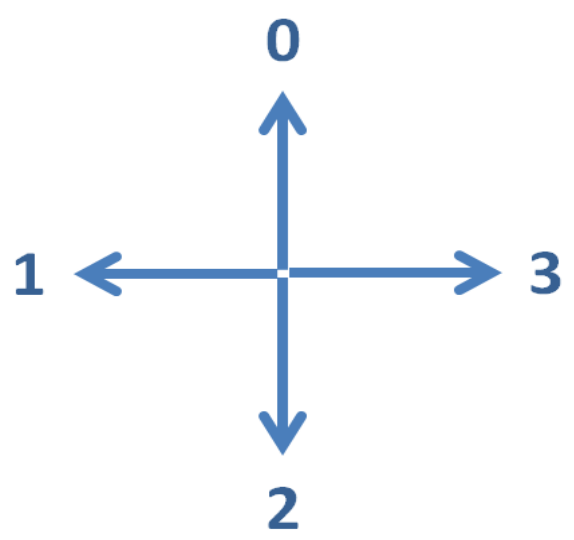

(b)

Figura 6.2: (a) Modelo do labirinto em cruz elevado implícito nos gráficos das trajetórias dos ratos reais e virtuais exibidos neste capitulo. As posições 1 a 5 e -1 a -5 correspondem aos braços fechados opostos. As posições 6 a 10 e -6 a -10 representam os braços abertos. 0 é a posição central. (b) Esquema das orientações seguido pelo rato virtual no labirinto.

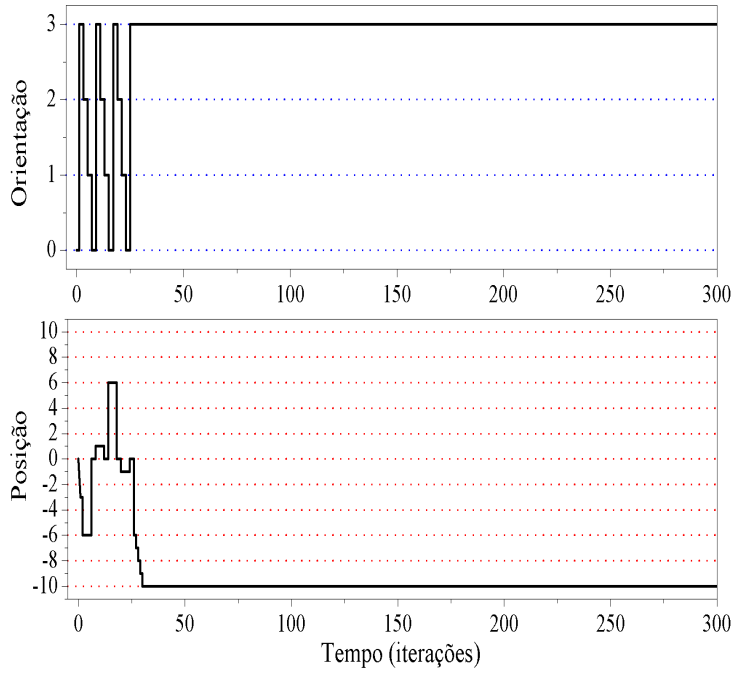

(a)

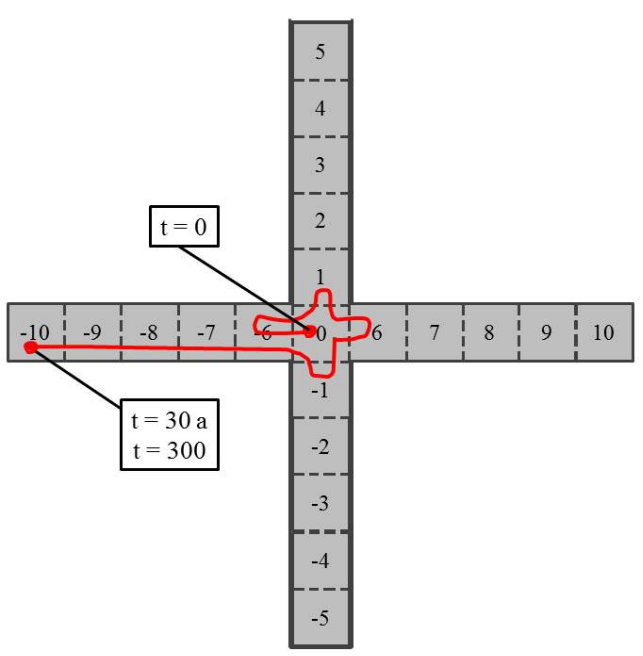

(b)

Figura 6.3: (a) Gráfico da trajetória desempenhada por um rato controle virtual que permaneceu parado no labirinto após periodo transiente de 30 passos de tempo da simulação computacional; (b) ilustração do labirinto em cruz elevado com a mesma trajetória do rato virtual. O esquema auxilia na compreensão do trajeto seguido por este agente. Curtas pausas não foram evidenciadas no esquema. 

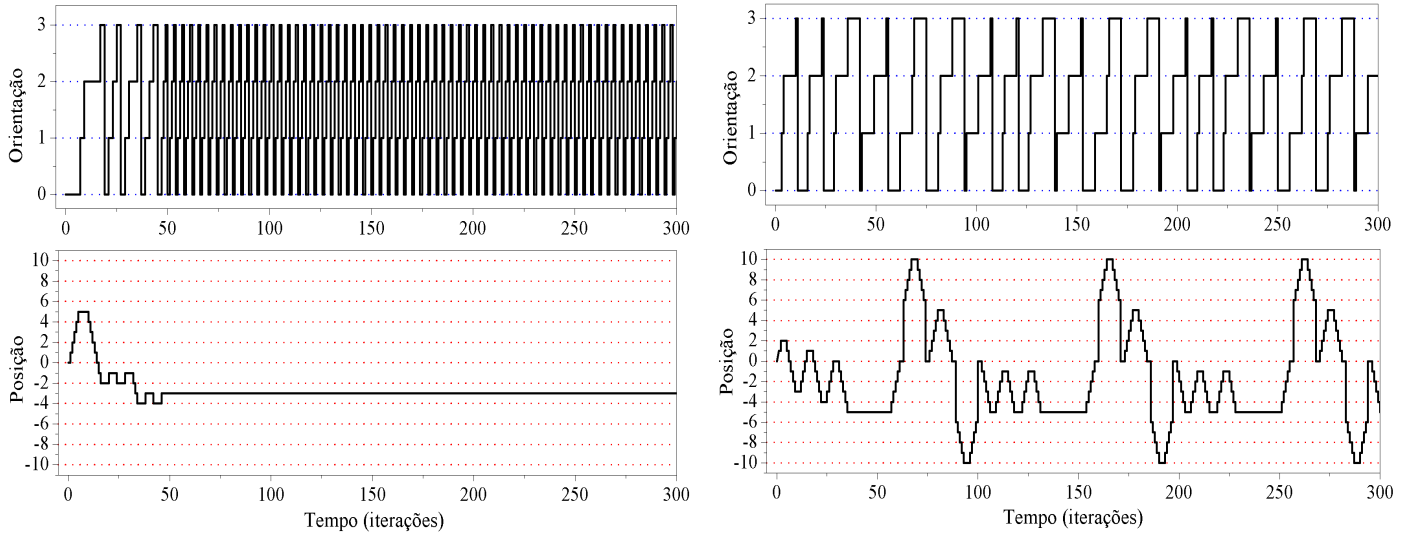

(a)

(b)
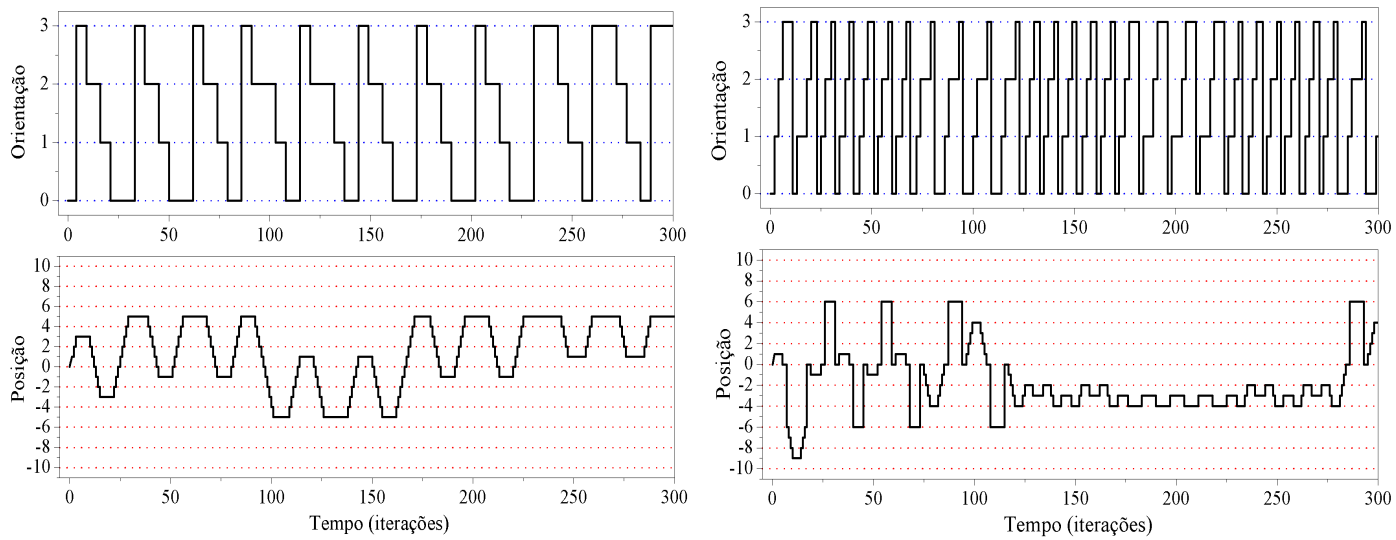

(c)

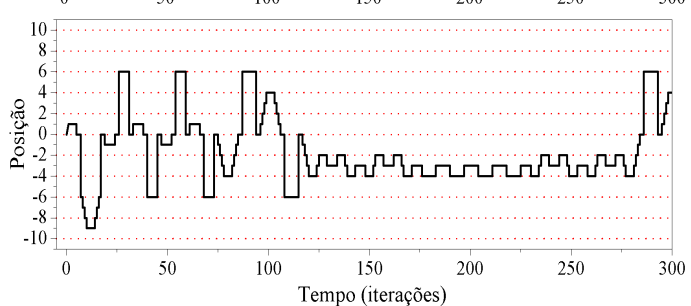

(d)
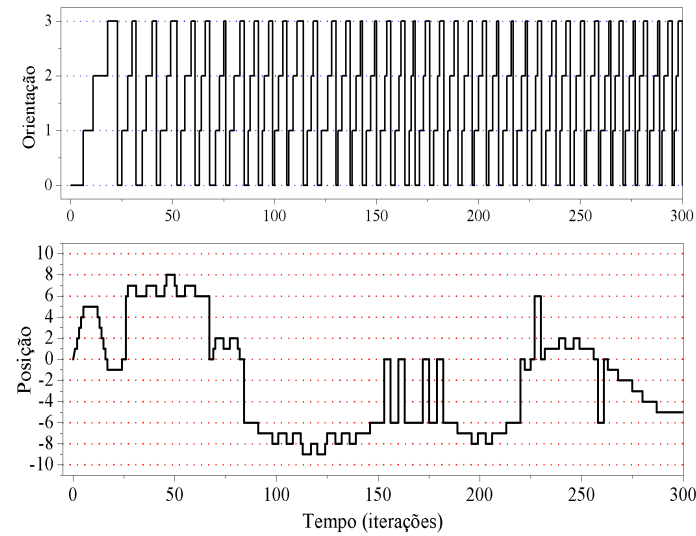

(e)

Figura 6.4: Diferentes trajetórias percorridas pelos ratos controle virtuais, exemplificando os comportamentos: (a) girando no lugar, (b) periódico, (c) estratégia se repete, (d) combinação de estratégias, (e) variável. 
Já na Figura 6.4(c) vemos um rato que não é periódico mas utiliza uma estratégia similar durante toda a trajetória. Nota-se que, diferentemente das trajetórias de outros ratos virtuais mostradas nas outras figuras, este rato virtual gira em sentido horário. Na Figura 6.4(d) observamos um rato virtual que faz uso de uma mesma estratégia durante parte do experimento e depois muda de estratégia: a primeira delas explora mais o labirinto, transitando tanto nos braços abertos quanto fechados; já na segunda estratégia adotada, o rato se restringe a um dos braços fechados, nas posições -2, -3 e -4. Por fim, a Figura 6.4(e) apresenta o caminho percorrido por um rato que não parece ter uma estratégia padrão, exibindo um comportamento variável no LCE.

Uma vez tendo exemplificado cada tipo de comportamento adotado pelos ratos virtuais, apresentamos na Tabela 6.4 quantos (e a porcentagem) dos 30 melhores ratos virtuais seguiram cada comportamento explicado anteriormente. Vemos que o comportamento mais comum é permanecerem parados após curto período transiente(9 ratos, 30,00\%). A maioria desses ratos fica parado em um dos braços fechados. Dessa forma, embora não ganhe recompena no momento de sua avaliação, pois não explora o labirinto, não perde tantos pontos por se manter em um braço "mais seguro". O mesmo é válido para os ratos que se mantêm girando numa mesma posição (5 ratos, 16,67\%).

Contudo, a maioria dos roedores virtuais adotam ao menos algum tipo de estratégia de movimento no LCE, seja ela periódica ou não, totalizando 12 ratos (40\%). Isso é previsível, dado que os ratos precisam "aprender" ao longo da evolução do algoritmo genético a serem recompensados com um ponto por explorar posições não visitadas recentemente, bem como a evitarem punição, principalmente nas áreas menos seguras (braços abertos). Com isso, muitos ratos acabam seguindo sempre a(s) mesma(s) estratégias ao longo do experimento no LCE para serem bem avaliados.

Obviamente, quando falamos de ratos reais não temos comportamentos tão demarcados como os dos ratos virtuais. Salienta-se que não temos dados de orientações dos ratos reais, mesmo porque esses ratos têm muito mais liberdade de movimentos do que os ratos virtuais. Ratos reais também desempenham outras ações além de movimentar-se, como mergulhar, coçar-se, esticar-se. Além disso, 


\begin{tabular}{|c|c|c|}
\hline Comportamento & $\begin{array}{c}\text { Quantidade de } \\
\text { ratos virtuais }\end{array}$ & $\begin{array}{c}\text { Porcentagem } \\
\text { de ratos virtuais }\end{array}$ \\
\hline \hline Parado & 9 & 30,00 \\
Girando na mesma posição & 5 & 16,67 \\
Periódico & 2 & 6,67 \\
Estratégia que se repete & 5 & 16,67 \\
Combinação de estratégias & 5 & 16,67 \\
Variável & 4 & 13,33 \\
\hline
\end{tabular}

Tabela 6.4: Quantidade e porcentagem de ratos virtuais a desempenhar cada tipo de comportamento geral observado no LCE virtual.

o tempo é contínuo, medido em milisegundos, divergindo do modelo de passos de tempo discreto com o qual trabalhamos.

Embora alguns comportamentos dos ratos virtuais pareçam pouco prováveis de ocorrem em experimentos com ratos reais, notamos que existem algumas similaridades entre eles. A Figura 6.5 mostra alguns exemplos de trajetórias de ratos reais.

Na Figura 6.5(a) vemos um rato que após 90,13 s ficou praticamente parado até o fim do experimento na extremidade de um braço fechado. Pode-se dizer que esse rato apresenta o comportamento "parado", assim como alguns ratos virtuais. Nas Figuras 6.5(b) e (c) percebemos animais que adotaram determinadas estratégias para se movimentar no labirinto. Na Figura 6.5(b), temos um rato que só ficou em um braço fechado, caminhando da posição adjacente ao centro à extremidade do braço, esperando um pouco quando atinge uma dessas posições. O rato da Figuras 6.5(c) também se mantém em um braço fechado, mas após um período transiente, no qual percorre também os braços abertos. Vemos que esse rato chega à extremidade e volta rápido até chegar à segunda posição do braço aberto, onde fica parado por um tempo e então repete essa estratégia. Por outro lado, o rato da Figuras 6.5(d) se locomove bastante, seguindo uma trajetória variável, sem padrões aparentes. Esse tipo de comportamento em ratos reais é o mais comum. 


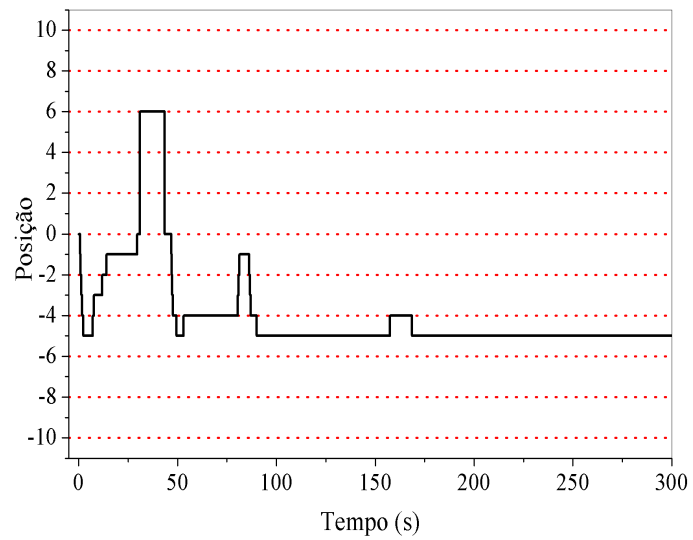

(a)

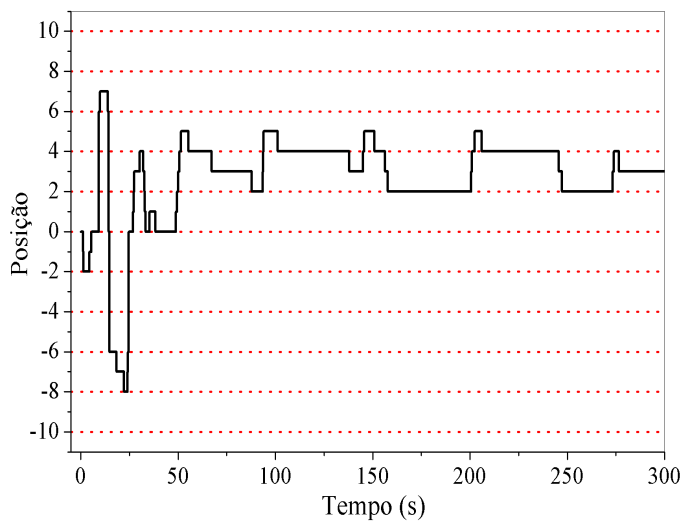

(c)

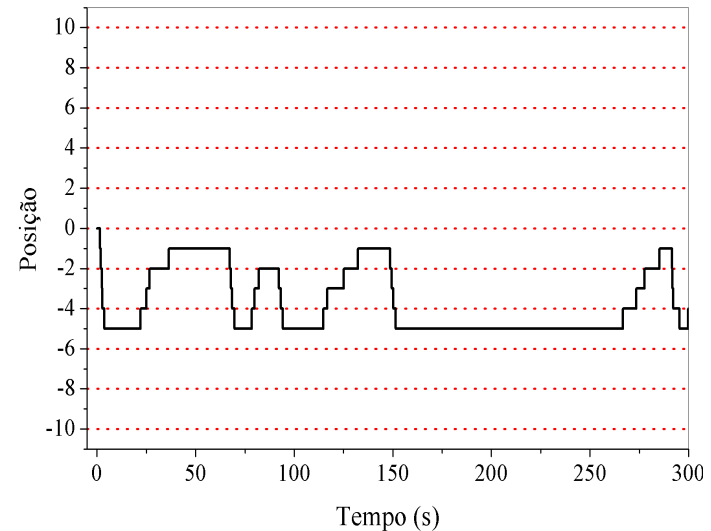

(b)

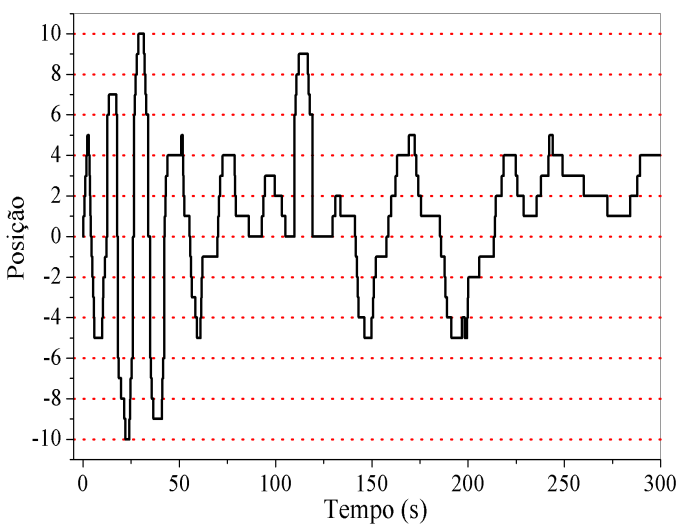

(d)

Figura 6.5: Diferentes trajetórias percorridas pelos ratos controle reais, exemplificando os comportamentos: (a) parado, (b) e (c) estratégia se repete, (d) variável.

Sabemos que o experimento padrão com ratos no LCE possuem a duração de cinco minutos, pois, como Montgomery mostrou, esses roedores perdem o interesse em explorar o labirinto após esse tempo [2]. Todavia, talvez o período de interesse exploratório seja ainda menor. Analisando as trajetórias dos ratos reais, concluímos que quase 30\% deles não se locomove nenhuma vez nos últimos (ao menos) 50 segundos do experimento, o que corresponde a mais de $16 \%$ do procedimento experimental. Se considermos os ratos que param, no mínimo, 25 segundos antes do fim do experimento, temos 20 deles (42,55\%). Esse tipo de comportamento é bem comum dentre os ratos virtuais também. 


\subsection{Estudo da ativação dos neurônios da RNA de ratos virtuais no $\mathrm{LCE}$}

Já estudamos as arquiteturas dos 30 melhores ratos controle virtuais, assim como suas trajetórias no labirinto em cruz elevado. Agora, buscaremos entender o papel desempenhado por cada neurônio da rede neural artificial no comportamento de dois ratos virtuais. A análise de cada um desses exemplos se encontra nas subseções seguintes.

\subsubsection{Exemplo 1}

Primeiramente analisaremos o comportamento de um rato pouco complexo, que se move por 5 iterações depois permanece absolutamente parado no labirinto. O gráfico com o percurso do rato virtual se encontra na Figura 6.6(a) e uma ilustração dos instantes $t=0$ a $t=5$ dessa trajetória é exibida na Figura 6.6(b), a qual também contém uma representação em escala de tons de cinza dos valores das entradas da RNA nesses 5 passos de tempo. As entradas E1 e E2 correspondem às saídas recorrentes dos neurônios intermediários 1 e 2, enquanto as entradas E3 e E4 são respectivamente os sensores à esquerda e frontal de curta distância (EC e FC), como mostra a Figura 6.7, que contém a rede neural artificial desse rato virtual.

Pelos pesos da RNA percebe-se que o sensor frontal de curta distância influencia negativamente (inativa) os dois neurônios intermediários, principalmente o neurônio 2 (N2). Já o outro sensor (de curta distância à esquerda) e as entradas vindas dos neurônios recorrentes ativam (positivamente) os neurônios intermediários (N1 e N2). Por sua vez, os neurônios intermediário ativam os neurônios de saída, sendo os maiores pesos sinápticos os existentes entre N1 e S4 $(4,18)$ e entre N1 e S1. A única exceção ocorre com N1, que inativa S3. 


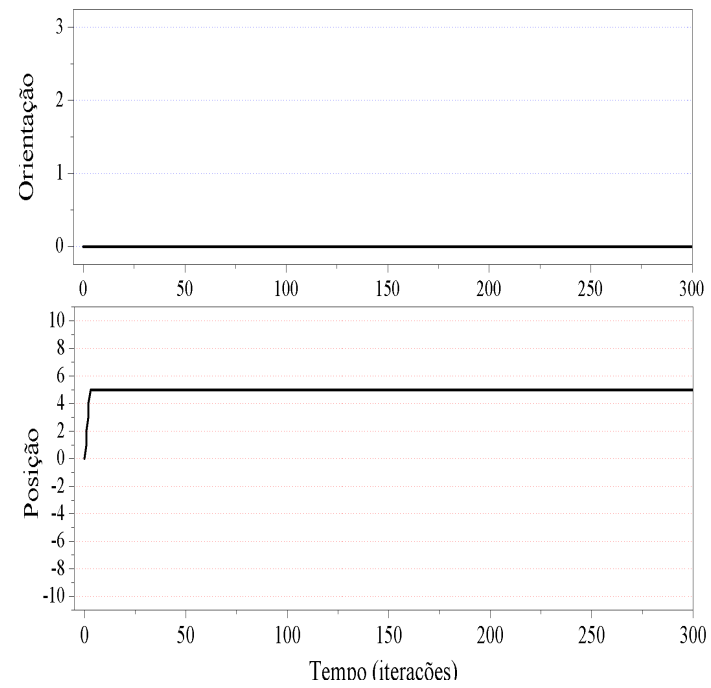

(a)

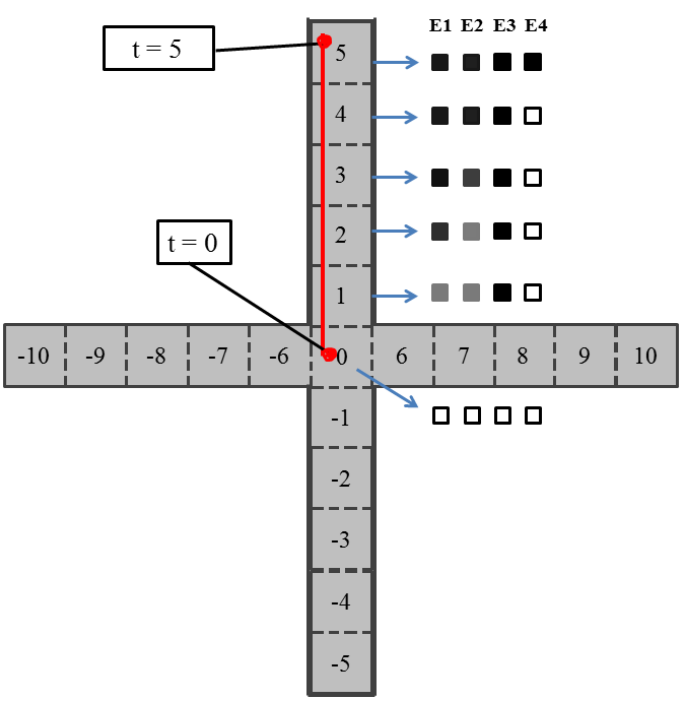

(b)

Figura 6.6: Trajetória desempenhada por um rato controle virtual que permaneceu parado no labirinto após 5 passos de tempo; (b) ilustração do labirinto em cruz elevado com a trajetória e uma representação dos valores de entrada da rede neural artificial em escala de cinza nos 5 primeiros passos de tempo. As entradas E1 e E2 são recorrências de neurônios intermediários e E3 e E4 são os sensores de curta distância à esquerda e à frente. Na escala de cores, preto corresponde ao valor 1,0 de entrada e branco, ao valor 0,0; valores intermediários equivalem a tons de cinza.

Na Figura 6.8 pode-se ver a ativação dos neurônios intermediários durante as 300 iterações computacionais que compreendem a trajetória do rato virtual. Observa-se um pico de ativação dos neurônios intermediários no início da trajetória, sendo o neurônio 1 mais ativo durante o curto período em que o rato se movimenta. Após a parada do rato, o neurônio 2 se mostra levemente mais ativo.

A Figura 6.9(a) traz os valores da ativação dos neurônios de saída S1 (F - ir para frente), S2 (E - virar para a esquerda), S3 (D - virar para a direita) e S4 (P - ficar parado) separadamente durante o percurso do rato virtual. Esses valores tornam-se estacionários na iteração $t=41$ e podem ser mais bem comparados na Figura 6.9(b), que apresenta os valores das ativações dos quatro neurônios de saída do início até o passo computacional $t=45$ da trajetória do rato. 


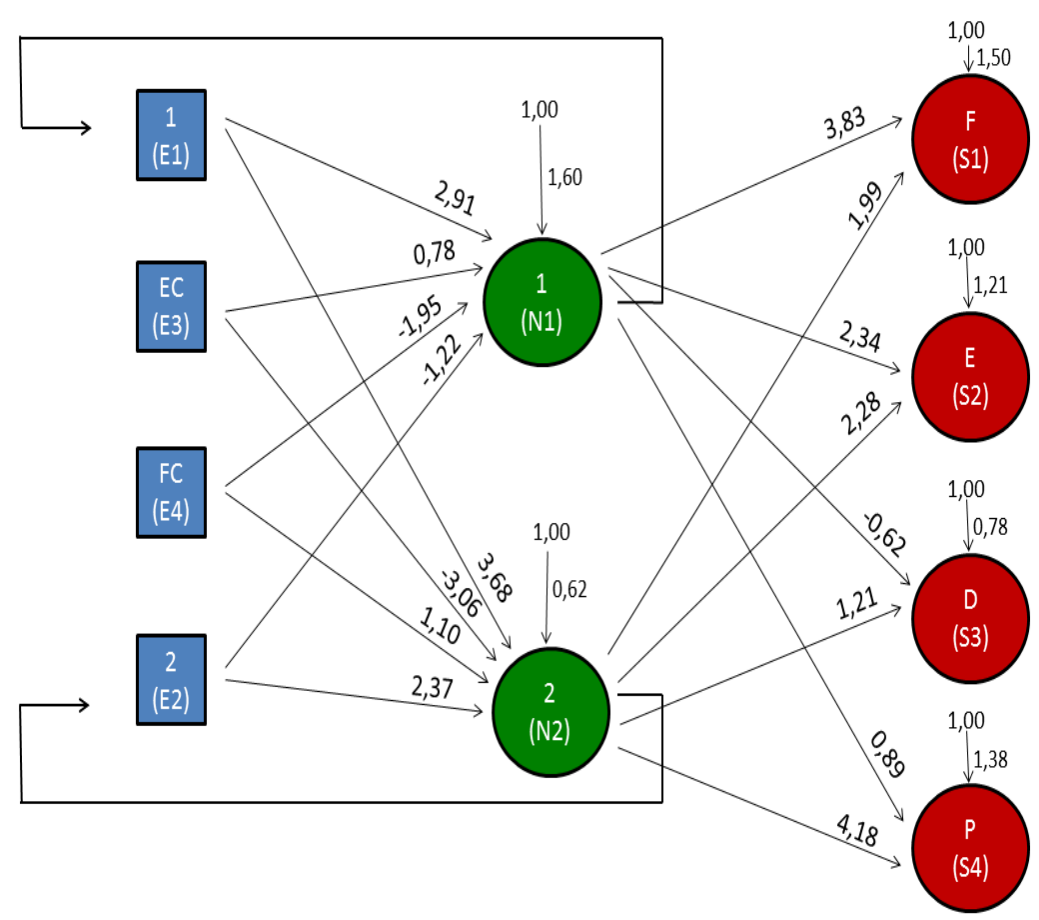

Figura 6.7: Rede neural artificial correspondente ao rato virtual cuja trajetória consta na Figura 6.6. A rede é composta por quatro elementos de entrada (E1, E2, E3, E4), sendo duas recorrências (E1 e E2) e dois sensores (E3 e E4), dois neurônios intermediários (N1, N2) e quatro neurônios de saída (S1 - seguir em frente $(F)$, S2 - virar à esquerda (E), S3 - virar à direita $(D)$ e $S_{4}$ - ficar parado $\left.(P)\right)$. Os pesos sinápticos são mencionados nas arestas do grafo. O bias de cada neurônio também é exibido na figura.

Nota-se que enquanto o sensor FC (entrada 4 da RNA) não está ativo, ou seja, entre $t=0$ e $t=4$, quando o rato se desloca em direção à extremidade do braço fechado, N1 prevalece mais ativo, o que favorece para que o rato virtual siga em frente (já que a ligação entre N1 e S1 (saída F) tem um peso sináptico forte, como já mencionado anteriormente $\left.\left(w_{N 1, S 1}=3,83\right)\right)$. Depois que o rato atinge a extremidade do braço fechado, N2 torna-se mais ativo (já que o sensor de parede frontal é ativado, com peso sináptico de $\left.w_{E 4, N 2}=1,10\right)$ e N1 diminui sua atividade, pois o peso entre E4 e N1 é negativo $\left(w_{E 4, N 1}=-1,95\right)$. Como N2 fica mais ativo e influencia fortemente S4 (saída P), o rato fica parado desde então. Assim, N1 é responsável por o rato seguir em frente e N2, por ele ficar parado. 

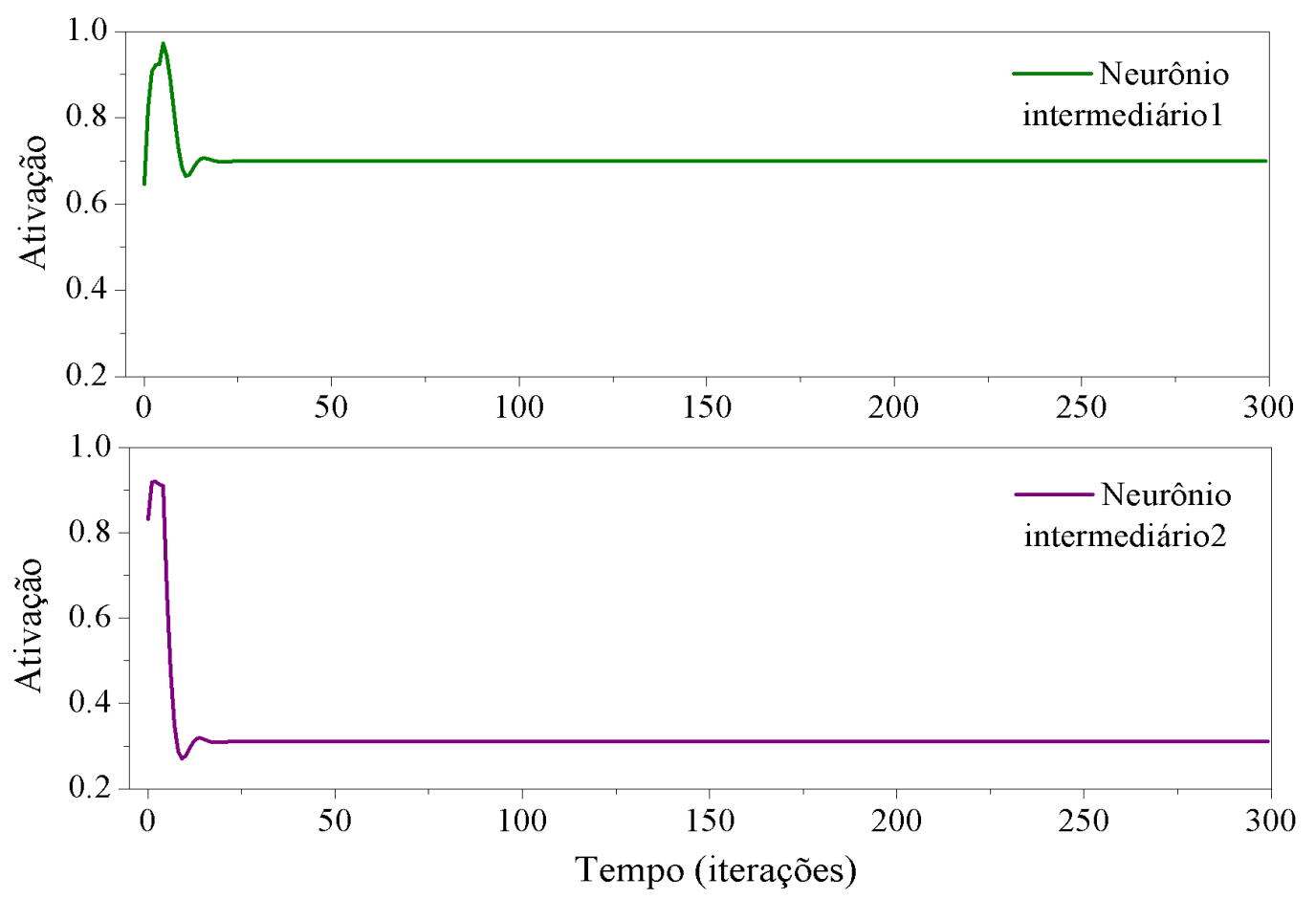

Figura 6.8: Ativação dos neurônios intermediários durante a trajetória exibida na Figura 6.6.

Este mecanismo se assemelha à ação dos núcleos da base no circuito motor, o qual é controlado por duas vias: a direta e a indireta. A via direta provoca a desinibição do tálamo e, por consequência, o aumento da ativação do córtex motor. A desinibição talâmica ocorre devido à ação inibitória das fibras estriado-palidais sobre os neurônios do pálido-interno (e da substância negra reticular) que, então, deixam de inibir o tálamo (as fibras pálido-talâmicas são mais importantes porque têm uma alta taxa de atividade espontânea e inibem tonicamente os neurônios talâmicos). Desinibido, o tálamo excita o córtex motor cuja atividade aumenta [75]. Deste modo, o predomínio da via direta pode ser representado pela ativação do neurônio N1, principal responsável por o rato virtual se mover para frente.

Já a via indireta desinibe o subtálamo e, consequentemente, inibe o tálamo e reduz a atividade do córtex motor. As fibras estriado-pálidas inibem o pálido lateral que possui ação inibitória sobre o subtálamo (as fibras pálido-subtalâmicas possuem alta atividade espontânea e inibem tonicamente o subtálamo). Assim, a inibição do pálido externo faz cessar sua ação inibitória sobre o subtálamo. Desinibido, o subtálamo passa a excitar o pálido interno possui ação inibitória em relação ao 

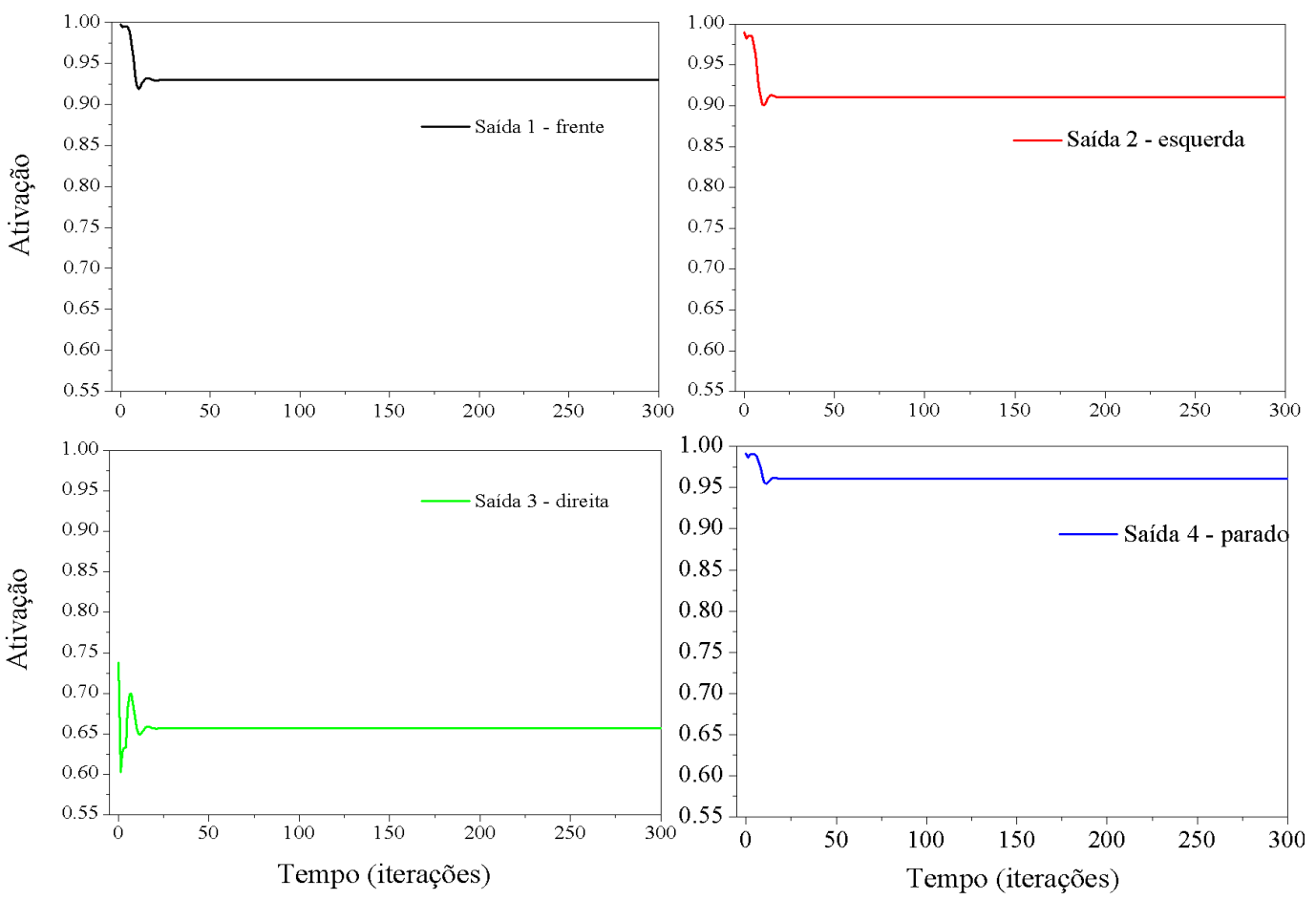

(a)

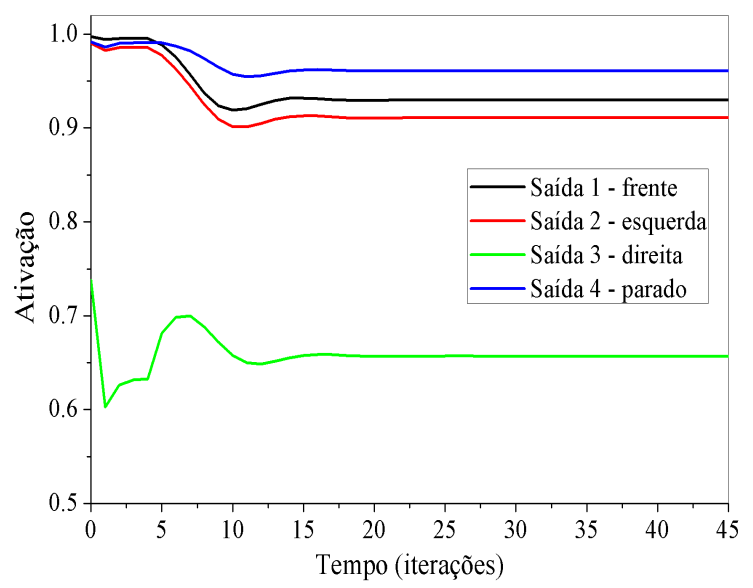

(b)

Figura 6.9: (a) Ativação dos neurônios de saída durante a trajetória exibida na Figura 6.6; (b) ativação de todos os neurônios de saída dos instantes $t=0$ a $t=45$ em um único gráfico, facilitando a comparação de seus valores.

tálamo. Após inibido, o tálamo deixa de ativar o córtex motor, que tem sua atividade diminuída [75]. O predomínio da via indireta pode ser representado, portanto, pelo neurônio intermediário 2 (N2) da rede neural estudada, pois este neurônio favorece que o rato virtual fique parado. 
É interessante notar que a ativação dos neurônios intermediários e de saída não atingem o estado estacionário no exato momento em que o rato virtual começa a ficar parado $(t=6)$, mas vão convergindo para este estado a partir de então.

Outro ponto interessante é que nos instantes $t=10$ a $t=18$ a saída da rede neural sugere que o rato siga em frente, porém está orientado para a parede do braço fechado e então não pode se mover, permanecendo parado. Essa é uma característica do modelo, que não possui nenhuma restrição a situações desse tipo.

\subsubsection{Exemplo 2}

Passaremos agora para a análise de um rato virtual que tem em sua trajetória um curto período transiente, seguido por um tipo de trajetória periódica, que é brevemente alterado por um novo tipo de trajetória periódica, o qual é adotado pelo agente computacional até o final dos 300 passos de tempo analisados. No primeiro comportamento periódico o rato explora os braços abertos, enquanto no segundo permanece em um único braço fechado. Toda esta trajetória pode ser vista na Figura 6.10.
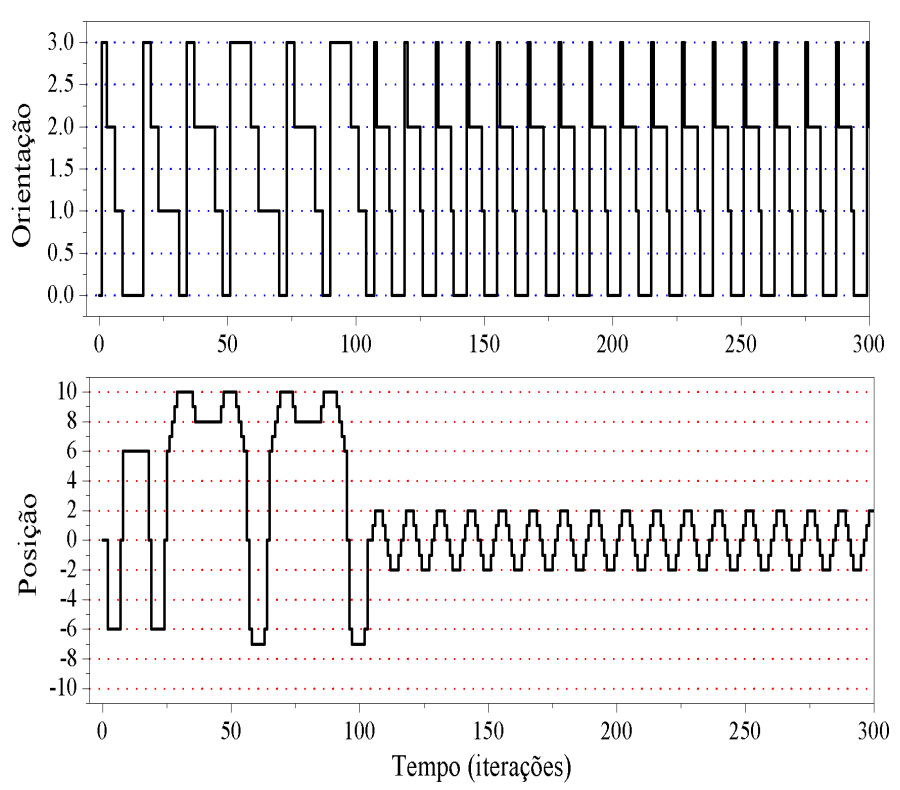

(a)

Figura 6.10: Trajetória de um rato virtual com dois tipos de comportamentos periódicos distintos. 
A rede neural artificial do rato virtual responsável pela trajetória acima encontra-se na Figura 6.11. A RNA contém na camada de entrada quatro recorrências de neurônios intermediários, um sensor frontal de curta distância e um sensor à esquerda de longa distância. Quatro neurônios compõem a camada intermediária. Na camada de saída estão os quatro neurônios que representam os comandos: ir para frente, virar à esquerda, virar à direita e ficar parado. O grande número de elementos em cada camada dificultaria a visualização e compreensão dos pesos sinápticos caso também fossem colocados na figura. Sendo assim, os pesos da RNA encontram-se nas Tabelas 6.5(a) e (b).

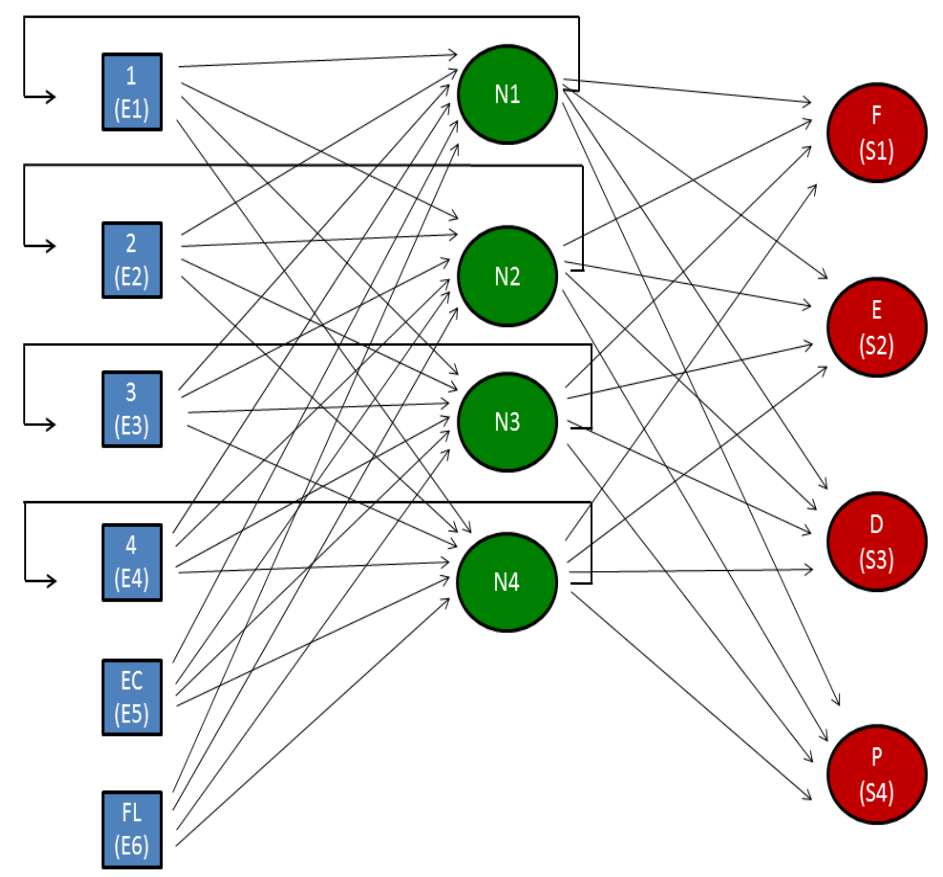

Figura 6.11: Rede neural artificial correspondente ao rato virtual cuja trajetória consta na Figura 6.6. A rede é composta por quatro elementos de entrada, sendo quatro recorrências de neurônios intermediários(E1, E2, E3, E4) e dois sensores (um à esquerda de curta distância, E5, e outro frontal de longa distância, E6), quatro neurônios recorrentes (N1, N2, N3, N4) e quatro neurônios de saída (S1 - seguir em frente (F), S2 virar à esquerda (E), S3 - virar à direita $(D)$ e $S 4$ - ficar parado (P)). Os pesos sinápticos das conexões da rede e os bias dos neurônios são apresentados na Tabela 6.5. 


\begin{tabular}{|c|c|c|c|c|}
\hline \multirow{2}{*}{ Entrada } & \multicolumn{4}{|c|}{ Pesos } \\
\cline { 2 - 5 } & $\mathrm{N} 1$ & $\mathrm{~N} 2$ & $\mathrm{~N} 3$ & $\mathrm{~N} 4$ \\
\hline \hline E1 & $-0,50$ & 2,61 & $-5,27$ & $-1,87$ \\
\hline E2 & 0,67 & $-1,92$ & $-4,99$ & 2,74 \\
\hline E3 & 0,18 & $-2,09$ & $-0,95$ & 3,03 \\
\hline E4 & 2,14 & $-4,56$ & $-1,94$ & $-4,78$ \\
\hline E5 & 2,94 & 1,06 & $-5,98$ & $-1,87$ \\
\hline E6 & $-4,96$ & 1,72 & $-0,40$ & $-3,46$ \\
\hline \multicolumn{5}{|c}{ (a) } \\
\hline
\end{tabular}

\begin{tabular}{|c|c|c|c|c|}
\hline \multirow{2}{*}{$\begin{array}{c}\text { Neurônio } \\
\text { Intermediário } \\
\end{array}$} & \multicolumn{4}{|c|}{ Pesos } \\
\hline & S1 & $\mathrm{S} 2$ & S3 & $\mathrm{S} 4$ \\
\hline N1 & 3,14 & $-0,47$ & $-1,47$ & $-1,43$ \\
\hline N2 & $-3,23$ & 1,95 & $-4,88$ & $-3,37$ \\
\hline N3 & $-3,02$ & 3,36 & $-2,02$ & 3,05 \\
\hline N4 & 3,75 & $-5,12$ & $-3,08$ & $-3,45$ \\
\hline
\end{tabular}

(b)

Tabela 6.5: Pesos sinápticos das conexões entre (a) elementos de entrada e neurônios intermediários, e (b) neurônios intermediários e de saída, referentes à RNA apresentada na Figura 6.11.

As ativações dos neurônios intermediários podem ser observadas na Figura 6.12. Nota-se que o neurônio 3 é o menos ativo ao longo da trajetória do agente. Dado que os pesos sinápticos entre este neurônio e todos os elementos pré-sinápticos a ele são negativos, o maior valor de N3 é atingido no instante inicial, quando todos os valores de entrada são nulos (exceto o bias do neurônio). Os demais neurônios intermediários apresentam ativação oscilatória com frequência alta durante a trajetória do agente. N1 e N2 atingem valores mais altos de ativação após a iteração computacional $t=$ 104, momento no qual há a troca de um tipo de comportamento periódico do rato virtual para outro tipo. O oposto acontece com N4, embora a diferença nos valores atingidos antes e depois desse período seja pouco expressiva.

A Figura 6.13(a) traz os valores da ativação dos neurônios de saída S1 (ir para frente), S2 (virar para a esquerda), S3 (virar para a direita) e S4 (ficar parado) separadamente durante o percurso do rato virtual. Já a Figura 6.13(b) exibe os valores das ativações dos quatro neurônios de saída juntos. 

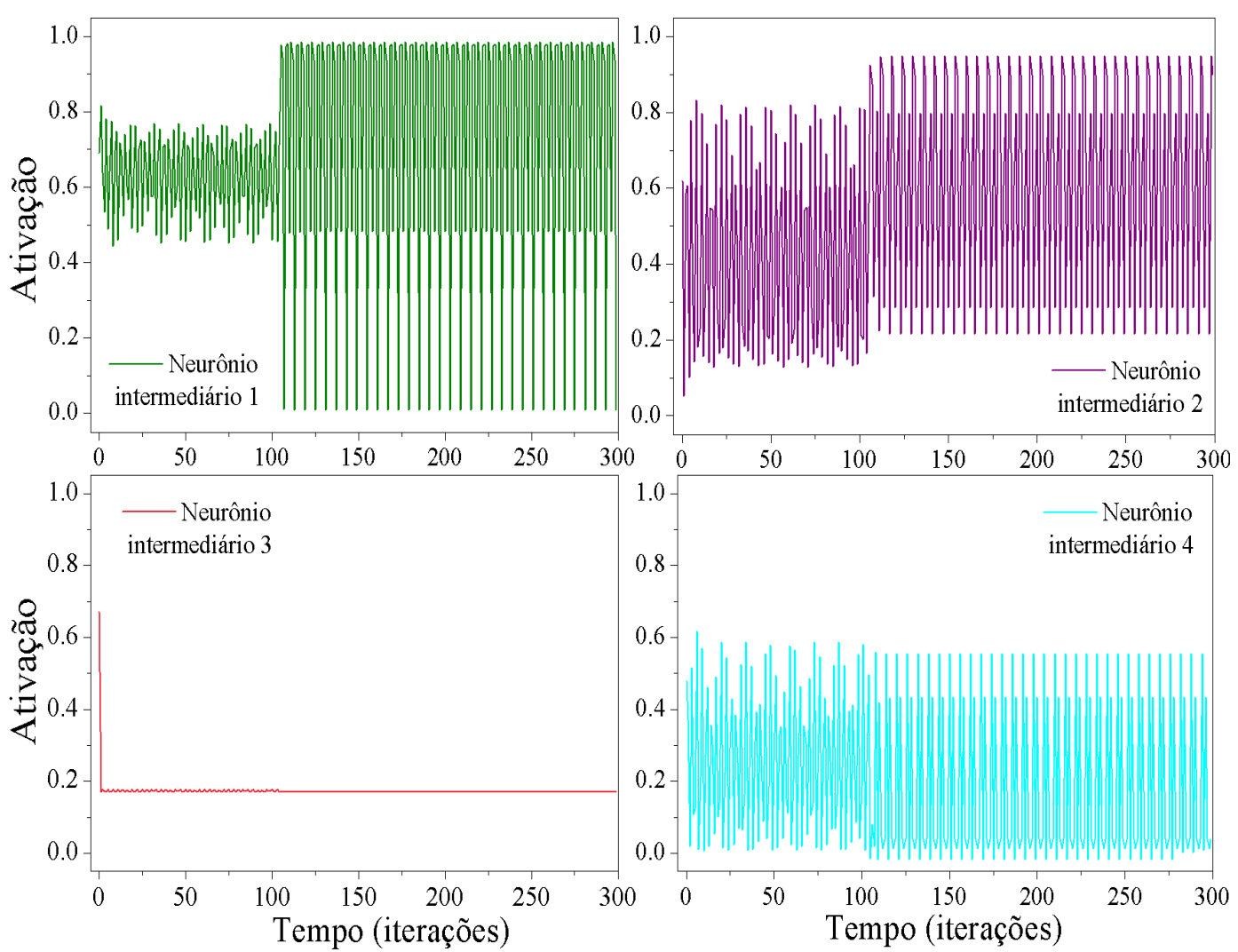

Figura 6.12: Ativação dos neurônios intermediários durante a trajetória exibida na Figura 6.10.

Para uma análise do papel dos neurônios do rato virtual, precisaremos dividir a trajetória em três etapas: início $(t=0$ a $t=24)$, exploração dos braços abertos $(t=24$ a $t=104)$ e exploração do braço fechado $(t=104$ a $t=300)$. 

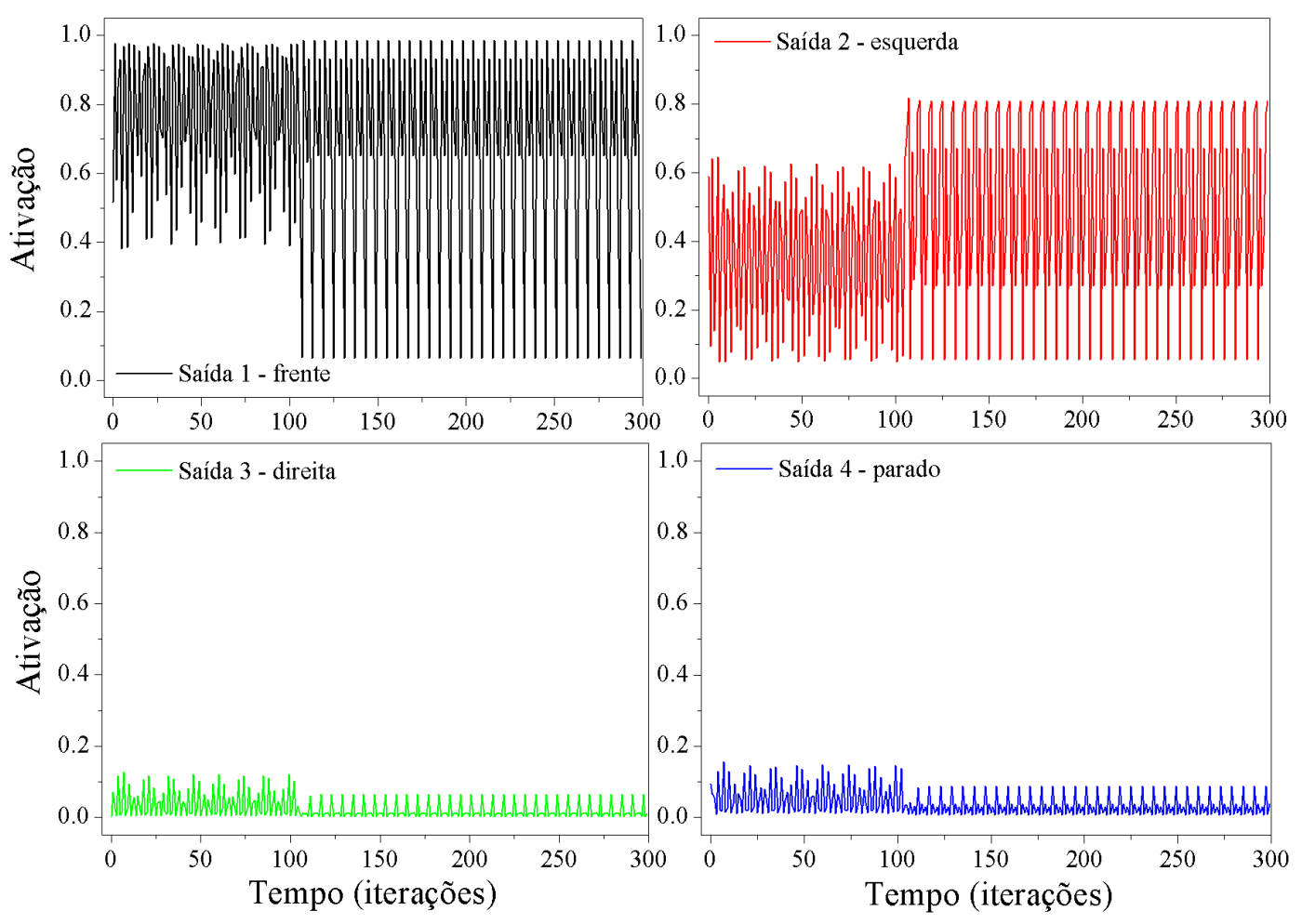

(a)

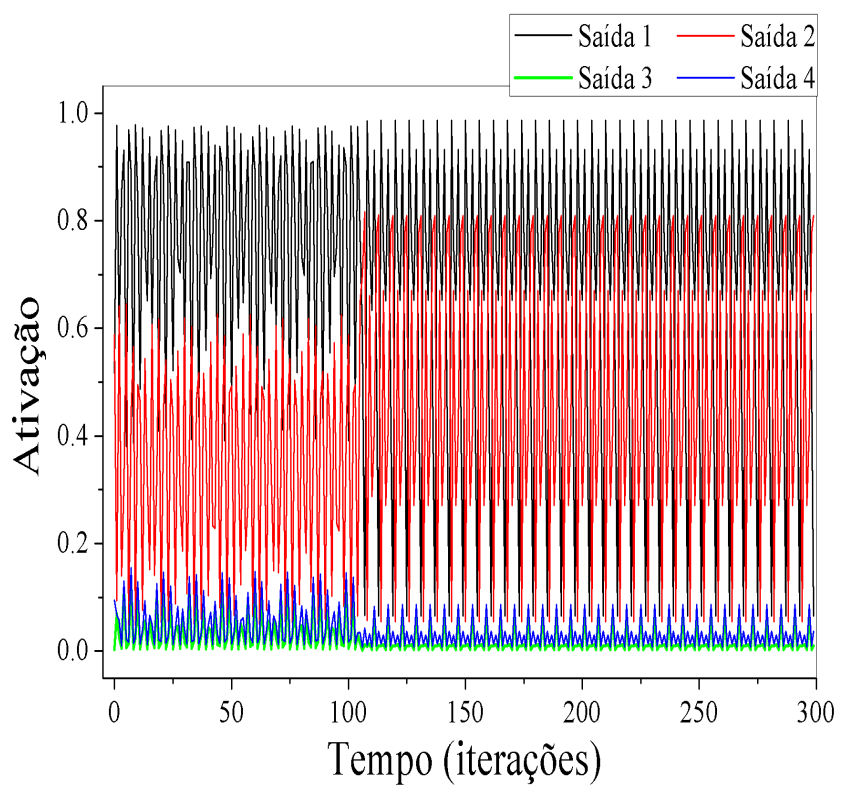

(b)

Figura 6.13: (a) Ativação dos neurônios de saída durante a trajetória exibida na Figura 6.6; (b) ativação de todos os neurônios de saída dos instantes $t=0$ a $t=45$ em um único gráfico, facilitando a comparação de seus valores. 


\subsubsection{Parte 1: início}

Percebe-se que o rato virtual, nos primeiros passos de tempo, move-se do centro para a primeira posição de um braço aberto, volta para o centro e vai para a primeira posição do outro braço aberto (isso acontece entre as iterações $t=0$ a $t=18$ ). De $t=19$ a $t=24$ a primeira metade desse comportamento é repetida (o rato entra no braço aberto e volta para o centro). Como há essa repetição, vamos exibir na Figura 6.14 apenas o que ocorre nas iterações $t=0$ a $t=18$ para facilitar a visualização. A trajetória e uma representação da ativação dos elementos da camada de entrada são vistos nas 6.14(a) e (b). Em 6.14(c) e (d) vemos as ativações dos neurônios intermediários e de saída, respectivamente.

As iterações em que a ativação de N2 é maior que a de N1 equivalem aos momentos em que o rato vira à esquerda, exceto nas iterações $t=11$ e $t=14$. Nas demais iterações, o N1 predomina, assim como a saída S1 (ou seja, o rato vai para frente). A exceção ocorre, pois N4 inativa fortemente S2 $\left(w_{N 4, S 2}=-5,12\right)$ e ativa consideravelmente $\mathrm{S} 1\left(w_{N 4, S 1}=3,75\right)$. Deste modo, embora N2 tenha sido maior em $t=11$ e $t=14$, o valor de $\mathrm{N} 4$ não foi baixo o suficiente para diminuir a diferença entre S1 e S2 provocada por este neurônio.

Assim, N2 é responsável por o rato mudar de direção e N1 por ele seguir em frente, auxiliado por N4. O neurônio 3 não possui relação aparente com o movimento do rato virtual no LCE, pois sua ativação é muito baixa ao longo de toda a trajetória. É notável, ainda, que nenhum sensor foi ativado, pois o rato se deslocou apenas no centro e nos braços abertos, onde não existem paredes. 


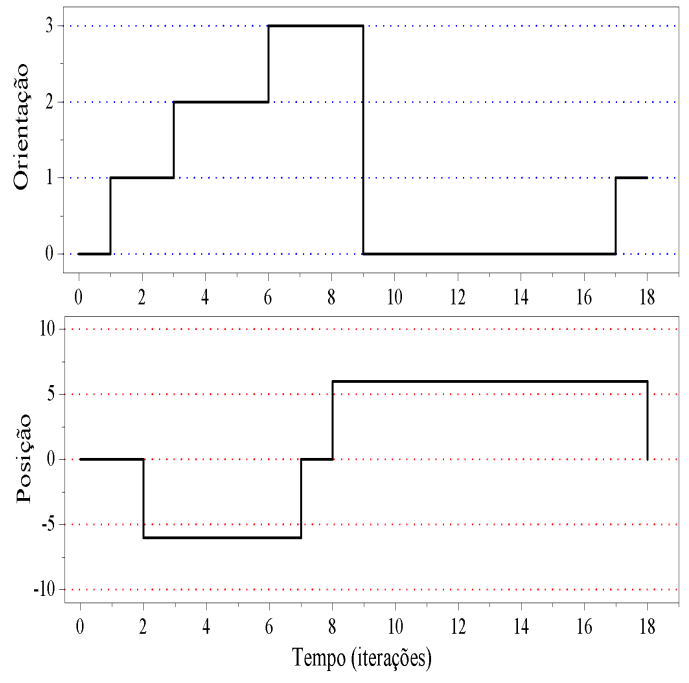

(a)

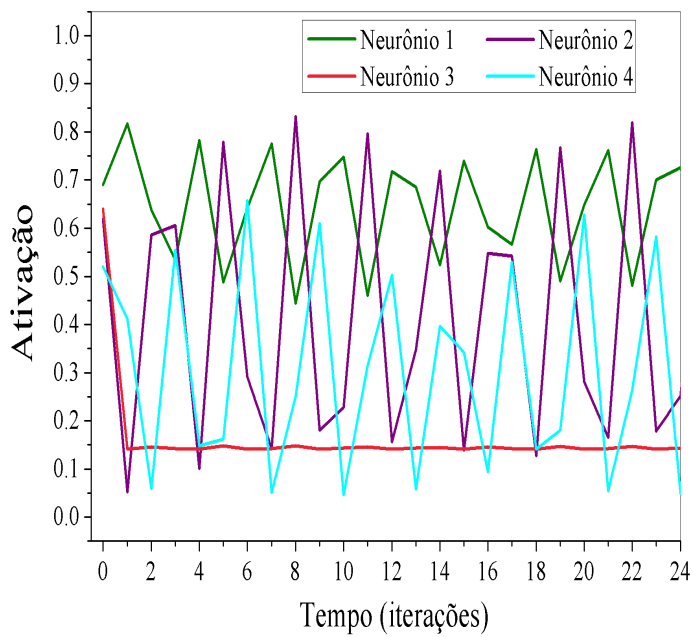

(c)

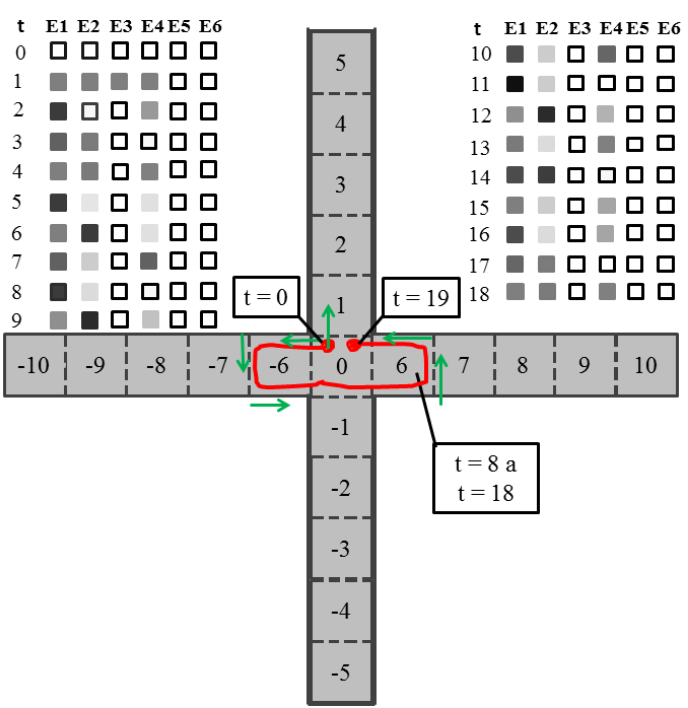

(b)

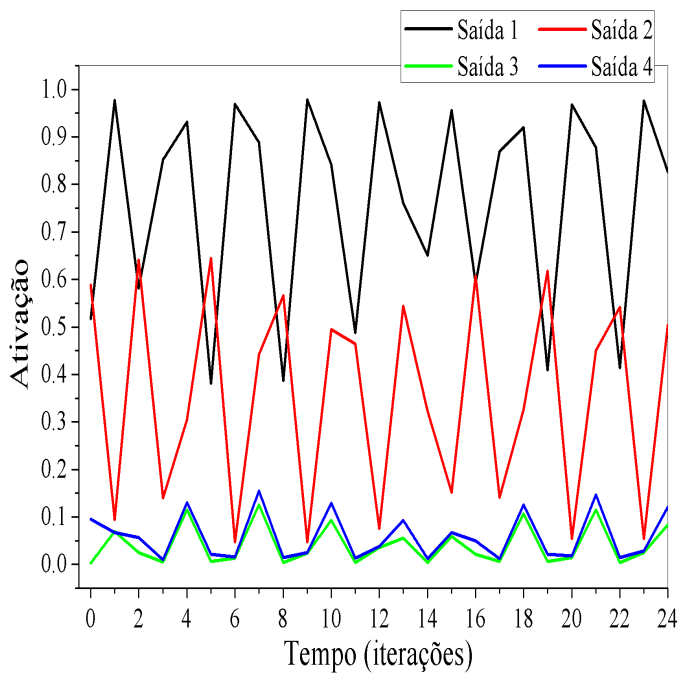

(d)

Figura 6.14: Trajetória desempenhada pelo rato virtual nos durante as iterações $t=0$ a $t=18$; (b) ilustração do labirinto em cruz elevado com a trajetória e uma representação dos valores de entrada da rede neural artificial em escala de cinza nesses passos de tempo (as setas verdes mostram a orientação do rato virtual); ativação dos neurônios (c) intermediários e (d) de saída correspondentes. 


\subsubsection{Parte 2: exploração de braços abertos}

Nesta etapa o rato explora os braços abertos repetindo um padrão com 40 passos de tempo de duração. A Figura 6.15(a) e (b) mostram um período desta trajetória, juntamente com a ativação dos neurônios intermediários (Figura 6.15(c)) e de saída (Figura 6.15(d)) neste período.

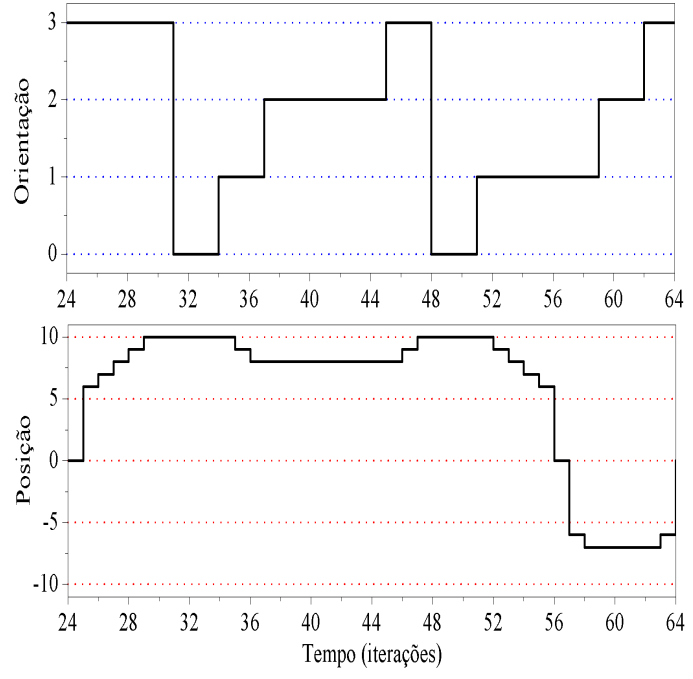

(a)

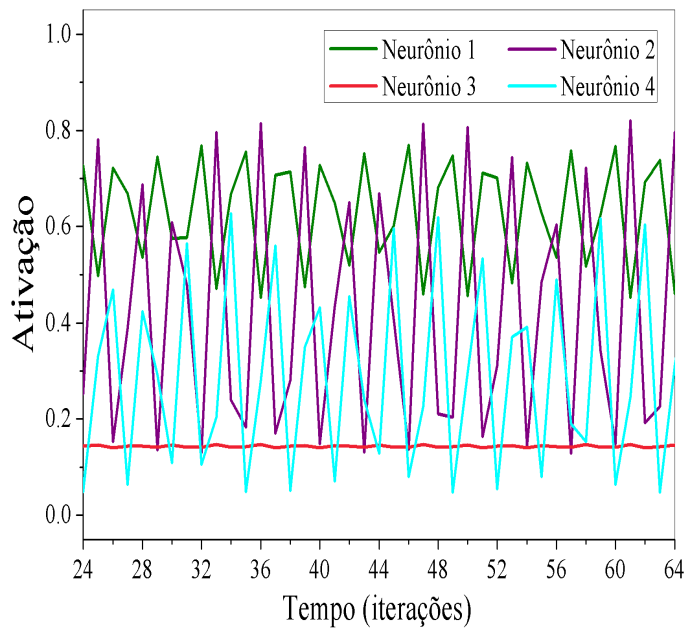

(c)

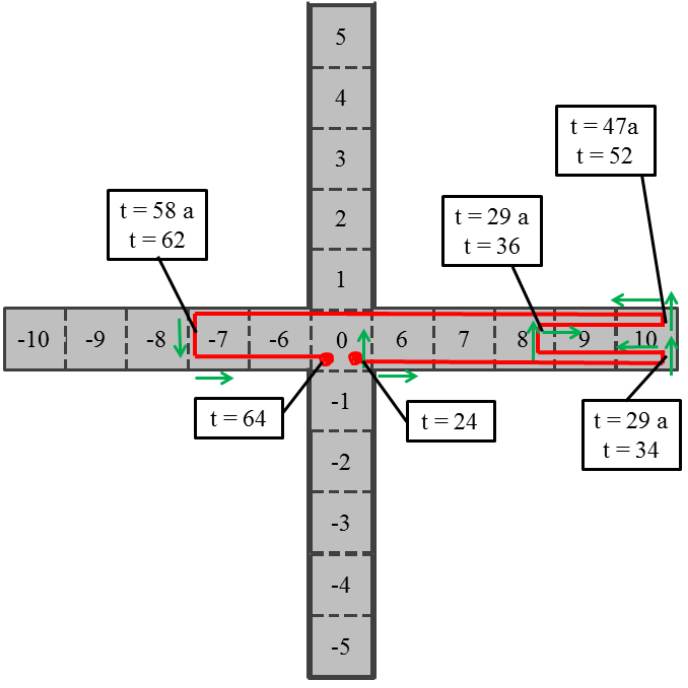

(b)

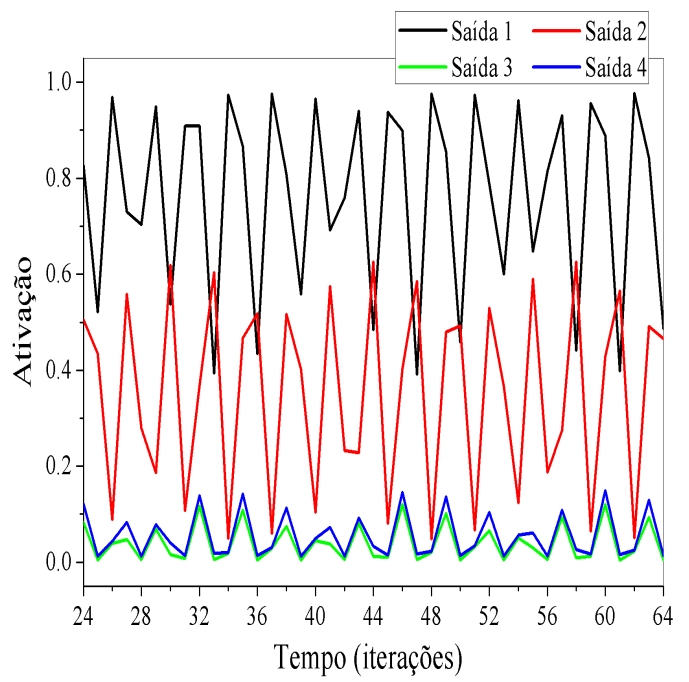

(d)

Figura 6.15: Trajetória desempenhada pelo rato virtual durante as iterações $t=24 a$ $t=64$; (b) ilustração do labirinto em cruz elevado com a trajetória e uma representação dos valores de entrada da rede neural artificial em escala de cinza nesses passos de tempo; ativação dos neurônios (c) intermediários e (d) de saída correspondentes. 


\subsubsection{Parte 3: exploração do braço fechado}

Esta etapa compreende a exploração dos braços fechados pelo rato virtual, a qual é a etapa mais longa. O mesmo comportamento se repete de $t=104$ a $t=300$.

A Figura 6.16 mostra um período desta trajetória repetitiva, juntamente com a ativação dos neurônios intermediários e de saída neste período.
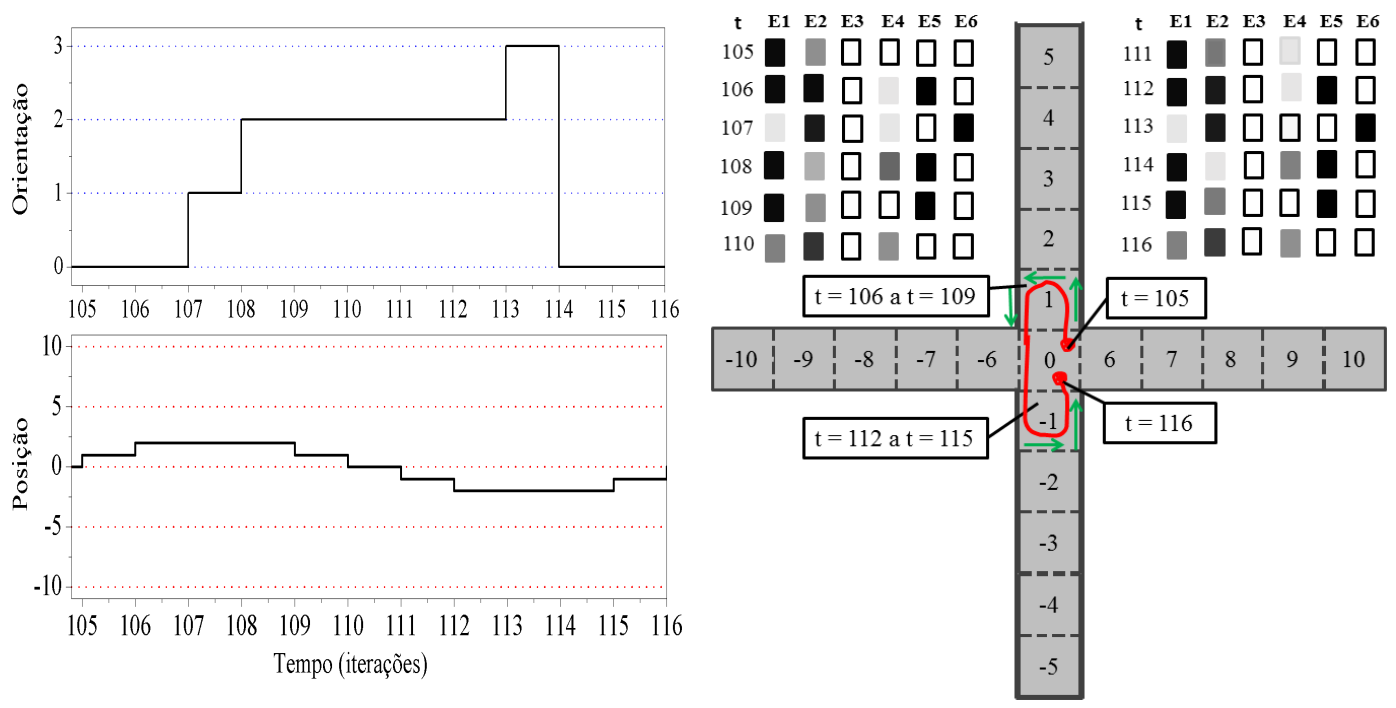

(a)

(b)

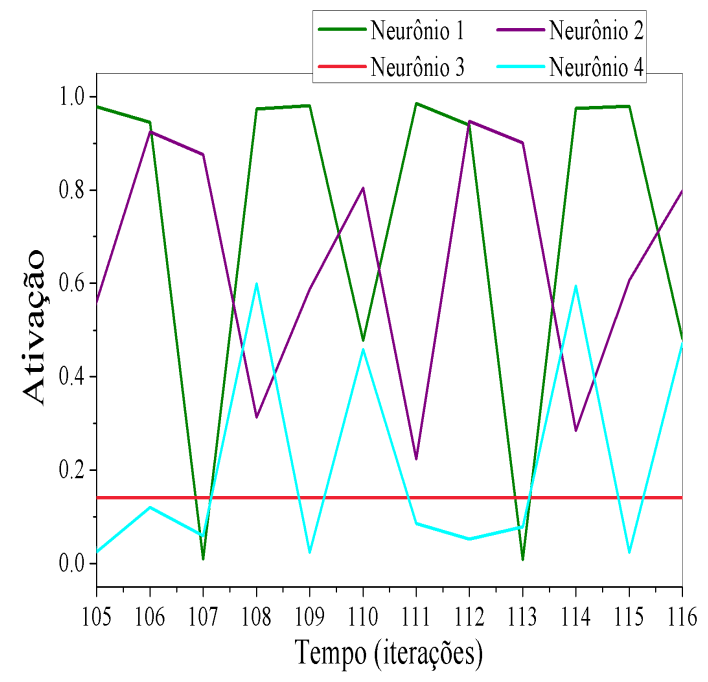

(c)

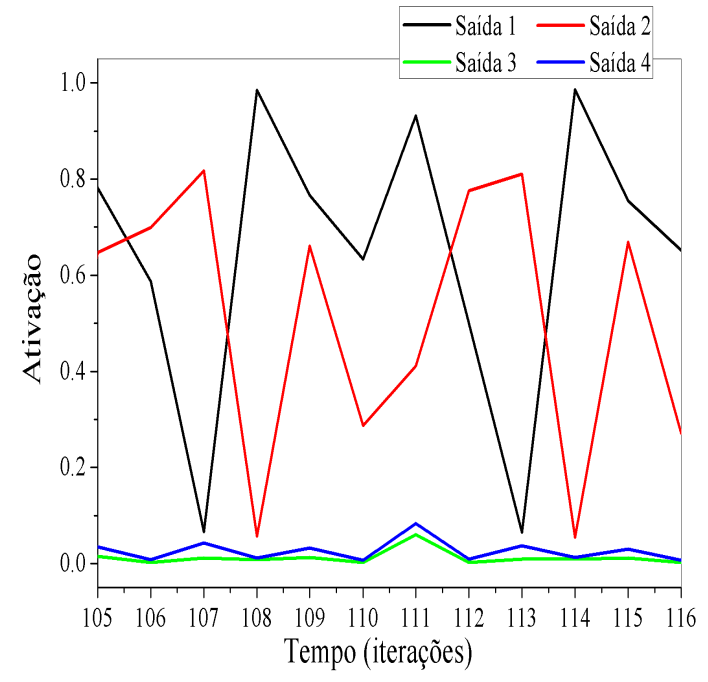

(d)

Figura 6.16: Trajetória desempenhada pelo rato virtual durante as iterações $t=104$ a $t=116$; (b) ilustração do LCE com a trajetória e uma representação dos valores de entrada da rede neural artificial em escala de cinza nesses passos de tempo; ativação dos neurônios (c) intermediários e (d) de saída correspondentes. 
Na Figura 6.16, vemos que o rato anda mais do que gira, ou seja, a saída 1 domina, sendo menor que a saída 2 apenas eventualmente.

Como os pesos da rede neural são constantes ao longo de toda a trajetória, mesmo havendo a troca de comportamento periódico do agente computacional, o papel dos neurônios na trajetória é o mesmo, como pode-se observar nas figuras apresentadas anteriormente. O rato virtual vira à esquerda quando o valor de N2 é maior que N1, mas apenas quando o valor de N4 for suficientemente baixo (já que este neurônio pré-sináptico (com bastante intensidade) inibe o neurônio de saída 2 e ativa o neurônio de saída 1).

\subsubsection{Transições de comportamento}

Por meio das Figuras 6.12 e 6.13 , vemos que na iteração $t=104$ (segunda transição) o comportamento de todos os neurônios se alteram: a amplitude de oscilação da ativação dos neurônios intermediários N1 e N2 aumenta expressivamente, o oposto ocorre com a amplitude de oscilação de N3, e, embora a amplitude de oscilação das ativações de N4 não se altere, a frequência da oscilação aumenta. Com isso, a amplitude e a frequência de oscilação das ativações de S3 e S4 diminuem. Porém, o que afeta de fato o comportamento do rato é que há um aumento na amplitude de oscilação da ativação de S2, aumentando o valor de seus picos; o mesmo acontece, de modo mais drástico, com S1. Dessa forma, S1 passa a ser ativado com maior frequência até que S2 por ventura seja ativado; como consequência, o rato virtual anda por mais iterações antes de virar do que ocorria nos comportamentos anteriores a essa transição $(t=0$ a $t=104)$. As chances de o rato permanecer parado por estar diante de uma parede e não conseguir seguir em frente também aumentam.

Uma questão interessante sobre as transições de comportamento é: já que dois ciclos completos de um comportamento específico são executados a partir de $t=24$, o que faz com que ao final do segundo ciclo esse comportamento mude ao invés de se repetir novamente? Para tentar responder essa pergunta, as Figuras 6.17(a) e (b) mostram a ativação dos neurônios intermediários e de saída a cada iteração desde $t=24$ até $t=114$ para analisarmos se existe algo que explicite a causa da mudança 
de comportamento do rato virtual ocorrida no passo computacional $t=104$.

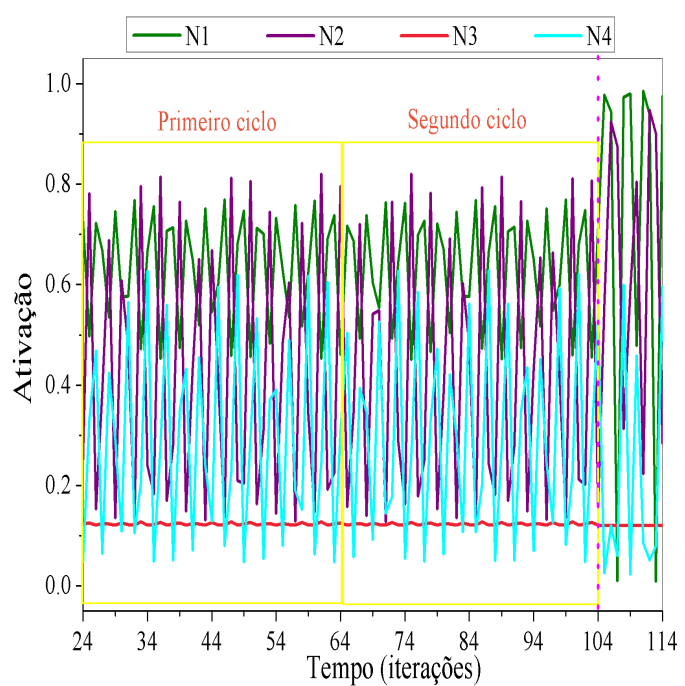

(a)

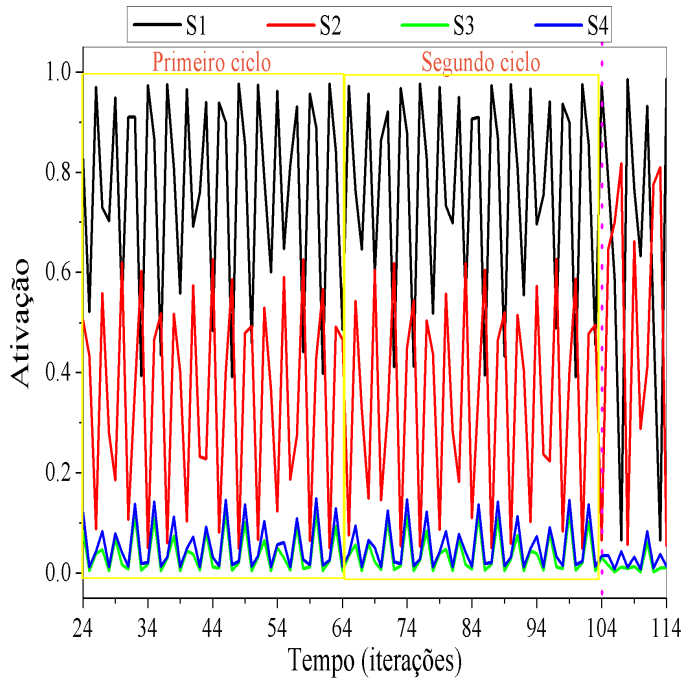

(b)

Figura 6.17: Ativações dos neurônios (a) intermediários e (b) de saída nas iterações $t=24$ a $t=114$. Em amarelo há um destaque para o período que compreende cada um dos ciclos comportamentais existente na região entre $t=24$ e $t=104$. A linha tracejada rosa ressalta o momento da transição comportamental do rato virtual $(t=104)$.

Observando as Figuras 6.17(a) e (b), vemos que as ativações dos neurônios durante os dois ciclos são bastante semelhantes, de modo que não pudemos identificar nada que indique a mudança de comportamento existente ao final do segundo ciclo. Assim, percebe-se que pequenas diferenças nas ativações dos neurônios são capazes de produzir grandes diferenças comportamentais nos ratos virtuais. Ou seja, as decisões tomadas (ações) não são exclusivamente reativas (isto é, uma ação nem sempre acarreta em uma (mesma) reação), dependendo portanto da memória de estados passados. Isso é evidenciado, já que as duas transições comportamentais do rato virtual apresentado acontecem quando ele se encontra no centro, onde não recebe nenhuma informação sensorial, ou seja, as transições comportamentais ocorreram em decorrência de memórias. No caso do modelo por nós estudado, é essencial portanto o papel das unidades recorrentes.

A partir das análises realizadas neste trabalho podemos inferir, ou ao menos hipotetizar, que a ativação cada vez maior de um grupo de neurônios (ou parte do cérebro) pode fazer com que a ativação de outros grupos de neurônios responsáveis 
pela ação de andar, por exemplo, supere a ativação do grupo de neurônios responsável por virar, e vice-versa, em ratos reais. O mesmo deve acontecer para as outras ações desempenhadas pelos ratos reais.

Após a apresentação de diversas trajetórias dos ratos virtuais, percebe-se que uma estratégia de navegação frequentemente adotada é a de andar por um tempo e depois girar, que é uma maneira de aumentar a exploração do ambiente. Também é notável que o rato virtual às vezes permanece algum tempo explorando os braços abertos, depois volta aos braços fechados, onde existe um risco menor. Essas estratégias se assemelham àquelas adotadas por ratos reais. 


\section{Capítulo}

\section{Conclusão}

Investigamos o uso de RNAs associadas a AGs para reproduzir o comportamento de ratos no labirinto em cruz elevado. Uma inovação em nossos modelos é que o rato virtual não é obtido utilizando-se dados de ratos reais (estes são usados apenas para avaliação da qualidade do modelo). Neste sentido, propusemos uma função de avaliação cuja variação de um único parâmetro permite a reprodução do efeito de drogas ansiogênicas e ansiolíticas no roedor (como exemplificado semicarbazida na concentração de 20, 40 e $80 \mathrm{mg} / \mathrm{kg}$ e clordiazepóxido $5 \mathrm{mg} / \mathrm{kg}$ ). Esse parâmetro balanceia o interesse exploratório e a punição de visitar posições em que o rato se encontra mais vulnerável no labirinto.

Estudamos dois tipos de modelos. Em um deles (Modelo 1) apenas os pesos da rede neural artificial são evoluídos pelo algoritmo genético, ao passo que no outro (Modelo 2) a arquitetura da rede (número de sensores e neurônios intermediários) também foram evoluídos. Assim como em experimentos com ratos reais, os ratos simulados exploram mais os braços fechados do que os abertos devido ao medo de uma maior exposição. Essa diferença é reduzida quando há a inserção de drogas ansiolíticas no animal, pois elas diminuem o medo (ansiedade) de navegar pelo ambiente, e é intensificado sob efeito de drogas ansiogênicas, que aumentam a ansiedade causada pela exploração. Os melhores casos foram obtidos com o segundo modelo mencionado. De acordo com as matrizes Markovianas (ou mais especificamente por seus vetores $\pi$ correspondentes), as transições de posições do rato virtual no labirinto possuem frequências de ocorrência similares a dos ratos reais (utilizando o Modelo 2).

Analisamos as arquiteturas das redes dos melhores ratos controle de 30 execuções 
do programa computacional. Dentre elas, 30\% possuem três ou quatro sensores, sendo a maioria deles de longa distância, assim como nos ratos reais, em que os olhos (sensores de longa distância) predominam em relação às vibrissas (sensores de curta distância). A maior parte dos ratos virtuais (36,37\%) possui três neurônios na camada oculta.

Vimos que os ratos virtuais, assim como os reais, apresentam diferentes tipos de comportamentos identificáveis em suas trajetórias no LCE. Podem ficar parados, mover-se livremente, adotar estratégia(s) periódica(s), girar constantemente na mesma posição ou usar uma estratégia especifica para mover-se de modo não periódico. Vimos que uma estratégia de navegação comumente adotada por ratos reais e virtuais é a de andar por um tempo e depois mudar sua orientação, o que favorece a exploração do ambiente. Também é notável que o rato virtual às vezes permanece algum tempo explorando os braços abertos, voltando posteriormente aos braços fechados, onde há um risco menor.

Mostramos que é possível identificar o papel dos neurônios da RNA na trajetória de ratos virtuais. Para isso, estudamos dois dos melhores ratos controle virtuais obtidos. A partir deste estudo pudemos hipotetizar que a ativação cada vez maior de um grupo de neurônios pode fazer com que a ativação de outro(s) grupo(s) de neurônios responsável(is) por determinada(s) ação(ões) do rato real supere a ativação de grupos de neurônios responsáveis por outras ações, implicando em um maior número de ações decorrentes do grupo dominante - assim como ocorre com os ratos virtuais.

Conforme sugerem os resultados, a função de avaliação proposta pode conter as características mais relevantes envolvidas no comportamento do rato no labirinto em cruz elevado. É claro que o modelo constitui uma grande simplificação da realidade, mas aparenta ser uma boa aproximação para descrever o comportamento de ratos no LCE.

\subsection{Perspectivas}

Temos perspectivas de trabalhos futuros decorrentes desta pesquisa de doutorado. Um primeiro trabalho será a análise da tomada de decisão do rato virtual 
simulando o efeito de drogas e o papel de seus neurônios, assim como fizemos com ratos virtuais controle. Também é possível aperfeiçoar o modelo, colocando mais detalhes realísticos, como o LCE contínuo ao invés de discreto ou comportamentos etolológicos, tais como coçar-se, mergulhar e esticar-se para o rato virtual. Além disso, o método pode ser adaptado para outros tipos de experimentos, como a arena ou labirintos complexos, por exemplo. Seria possível, ainda, investigar mais a fundo as implicações biológicas do método com o auxílio de neurocientistas.

Durante o doutorado, pesquisas paralelas relacionadas ao projeto principal foram realizadas. Assim, temos um projeto decorrente é que é a escrita de um artigo sobre o cálculo da ordem do processo estocástico resultante da trajetória de ratos reais controle e com Alzheimer (induzido) no LCE. Outro trabalho decorrente é a proposição de uma nova análise Markoviana para o comportamento de ratos no LCE. 


\section{Referências Bibliográficas}

[1] D. Goldberg. Genetic algorithms in search, optimization and machine learning. Alabama: Addison Wesley, 1989.

[2] K. C. Montgomery. The relation between fear induced by novel stimulation and exploratory behavior. Journal of Comparative and Physiological Psychology, 48:254-260, 1955.

[3] S. Hogg. A review of the validity and variability of the elevated plus-maze as an animal model of anxiety. Pharmacology Biochemistry, and Behavior, 54(1):21-30, 1996.

[4] F. G. Graeff. Handbook of anxiety, vol 3. The neurobiology of anxiety, chapter Brain defense systems and anxiety. Amsterdam: Elsevier Science Publishers, 1990.

[5] S. Handley and S. Mithani. Effects of alpha-adrenoceptor agonists and antagonists in a maze-exploration model of Śfear ̌̆- motivated behaviour. Naunyn-SchmiedebergŠs Archives of Pharmacology, 327:1-5, 1984.

[6] S. Pellow, P. Chopin, S. E. File, and M. Briley. Validation of open closed arm entries in an elevated plus-maze as a measure of anxiety in the rat. Journal of Neuroscience Methods, 14(3):147-167, 1985.

[7] C. Salum, A. C. Roque da Silva, and S. Morato. Conflict as a determinant of rat behavior in three types of elevated plus-maze. Behavioural Processes, 63:87-93, 2003.

[8] A. A. Walf and C. A. Frye. The use of the elevated plus maze as an assay of anxiety-related behavior in rodents. Nature Protocols, 2:322-328, 2007. 
[9] D. Treit, J. Menard, and C. Royan. Anxiogenic stimuli in the elevated plus-maze. Pharmacology, Biochemistry and Behavior, 44(2):463-469, 1993.

[10] A. M. Garcia, F. P. Cardenas, and S. Morato. Effect of different illumination levels on rat behavior in the elevated plus-maze. Physiology $\&$ Behavior, $85(3): 265-270,2005$.

[11] S. Morato. O papel da visão na aversão aos espaços abertos no labirinto em cruz elevado. Psicologia USP, 17(4):159-174, 2006.

[12] J. T. Imhof, Z. M. I. Coelho, M. L. Schmitt, G. S. Morato, and A. P. Carobrez. Influence of gender and age on performance of rats in the elevated plus maze apparatus. Behavioural Brain Research, 56(2):177-80, 1993.

[13] T. L. Doremus, E. I. Varlinskaya, and L. P. Spear. Age-related differences in elevated plus maze behavior between adolescent and adult rats. Annals of the New York Academy of Sciences, 1021:427-430, 2004.

[14] S. A. Ferguson and E. P. Gray. Aging effects on elevated plus maze behavior in spontaneously hypertensive, wistar-kyoto and sprague-dawley male and female rats. Physiology and Behavior, 85(5):621-628, 2005.

[15] S. S. Almeida, J. Tonkins, and J. R. Galler. Prenatal protein malnutrition affects exploratory behavior of female rats in the elevated plus-maze test. Physiology and Behavior, 60(2):675-680, 1996.

[16] G. M. S. Moreira, M. Araujo, L. M. Oliveira, and S. S. Almeida. The behavior of protein-calorie-malnourished rats on the elevated plus- maze test: An ethopharmacological analysis. Psychobiology, 25(2):180-185, 1997.

[17] A. Cabral and S. S. Almeida. Effects of tactile stimulation and underwater trauma on the behavior of protein-malnourished rats in the elevated plus-maze test. Psychology \& Neuroscience, 1(1):67-72, 2008.

[18] J. M. Giddings. Modeling the Behavior of Rats in an Elevated Plus-Maze. PhD thesis, Acadia University, 2002. 
[19] C. Salum, A. C. Roque da Silva, and S. Morato. Anxiety-like behavior in rats: a computational model. Neural Networks, 13(1):21-29, 2000.

[20] D. A. Miranda, C. A. Conde, C. C. Celis, and S. P. Corzo. Modelado del comportamiento de ratas en laberinto en cruz elevado basado en redes neuronales artificiales. Revista Colombiana de Física, 41(2):406-408, 2009.

[21] H. K. Shimo, J. Tejada, A. C. Roque, and R. Tinós. Use of evolutionary robots as an auxiliary tool for developing behavioral models of rats in an elevated plus-maze. In: Proceedings of the 2010 Eleventh Brazilian Symposium on Neural Networks, 2010.

[22] J. Tejada, G. G. Bosco, S. Morato, and A. C. Roque. Characterization of the rat exploratory behavior in the elevated plus-maze with markov chains. Journal of Neuroscience Methods, 193(2):288-295, 2010.

[23] A. A. Costa, A. C. Roque, S. Morato, and R. Tinós. Lecture Notes in Computer Science. 1a ed, v. 7435, chapter Model Based on Genetic Algorithm for Investigation of the Behavior of Rats in the Elevated Plus-Maze, pages 151-158. Berlin: Springer Berlin Heidelberg, 2012.

[24] A. A. Costa, P. A. Vargas, and R. Tinós. Using explicit averaging fitness for studying the behaviour of rats in a maze. In Proceedings of the Twelfth European Conference on Artificial Life - ECAL, 2013.

[25] A. A. Costa and R. Tinós. An evolving artificial neural network for the investigation of rat exploratory behavior. In 2014 Brazilian Conference on Intelligent Systems, 103-108. 2014.

[26] A. A. Costa, S. Morato, A. C. Roque, and R. Tinós. A computational model for exploratory activity of rats with different anxiety levels in elevated plus-maze. Journal of Neuroscience Methods, 236:44-50, 2014.

[27] H. L. Steenbergen, F. Farabollini, and R. P. W. Heinsbroek. Sex-dependent effects of aversive stimulation on holeboard and elevated plus-maze behavior. Behavioural Brain Research, 43(2):159-65, 1991. 
[28] F. K. Marcondes, K. J. Miguel, L. L. Melo, and R. C. Spadari-Bratfisch. Estrous cycle influences the response of female rats in the elevated plus-maze test. Physiology \& Behavior, 74(4-5):435-440, 2001.

[29] X. Xiang, W. Hao, and T. A Kosten. Sex difference in performance in elevated plus maze and hippocampal glur1 level. Journal of Central South Univerity, 36(8):750-3, 2011.

[30] T. P. Chaves C. A. Silva A. L. Mascarim E. J. Arruda, J. H. Kitamura. Comportamento exploratório e ansiolítico de ratos e ratas submetidos à estimulação somatossensorial. Revista Brasileira de Terapia e Saúde, 2(1):7-12, 2011.

[31] S. Nolfi and D. Floreano. Evolutionary Robotics: The Biology, Intelligence, and Technology of Self-Organizing Machines. MA: The MIT Press, 2000.

[32] J. Kemeny and J. Snell. Finite Markov chains. NJ: Springer, 1976.

[33] P. Haccou, H. Dienske, and E. Meelis. Analysis of time-inhomogeneity in markov chains applied to mother-infant interactions of rhesus monkeys. Animal Behaviour, 31(3):927-945, 1983.

[34] E. Garcia-Perez, A. Mazzoni, D. Zoccolan, H. P. Robinson, and V. Torre. Statistics of decision making in the leech. The Journal of Neuroscience, 25:2597-2608, 2005.

[35] H. Yang and A. Chao. Modeling animals' behavioral response by markov chain models for capture-recapture experiments. Biometrics, 61(4):1010-1017, 2005.

[36] S. L. Handley and J. W. McBlane. An assessment of the elevated x-maze for studying anxiety and anxiety-modulating drugs. Journal of Pharmacological and Toxicological Methods, 29(3):129-138, 1993.

[37] R. J. Rodgers and J. C. Cole. Ethology and Psychopharmacology, chapter The elevated plus-maze: pharmacology, methodology and ethology. Chichester: Wiley, 1994. 
[38] G. R. Dawson and M. D. Tricklebank. Use of the elevated plus-maze in the search for novel anxiolytic agents. Trends in Pharmacological Sciences, 16(2):33-36, 1995.

[39] L. J. Bertoglio and A. P. Carobrez. Anxiolytic effects of ethanol and phenobarbital are abolished in test-experienced rats submitted to the elevated plus maze. Pharmacology, Biochemistry and Behavior, 73(4):963-969, 2002.

[40] A. P. Braga, T. B. Ludermir, and A. C. P. L. F. Carvalho. Redes Neurais artificiais - teoria e aplicações. RJ: LCT, 2000.

[41] I. N. da Silva, D. H. Spatti, and R. A. Flauzino. Redes neurais artificiais para engenharia e ciências aplicadas - curso prático. ArtLiber, 2010.

[42] B. F. Skinner Science and human behavior Simon \& Schuster Inc, 1953.

[43] Jorge M. Barreto. Indrodução às redes neurais artificiais. Indrodução às Redes Neurais Artificiais, disponível em http://www.inf.ufsc.br/ barreto/tutoriais/Survey.pdf. Acesso em 03/2013.

[44] Marvin Minsky and Seymour Papert. Perceptrons: an introduction to computational geometry. 1969.

[45] J. Hertz, A. Krogh, and R. G. Palmer. Introduction to the theory of neural computation. Addison-Wesley Publishing Company, 1991.

[46] Simon Haykin. Redes neurais: Princípios e prática. Porto Alegre: Bookman, 2a ed., 2001.

[47] E. G. M. Lacerda and A. C. P. L. Carvalho. Sistemas inteligentes: aplicações a recursos hídricos e ciências ambientais, chapter Introdução aos algoritmos genéticos. Porto Alegre: Ed. Universidade/UFRGS : Associação Brasileira de Recursos Hídricos, 1999.

[48] C. Darwin. On the Origin of Species by Means of Natural Selection, or the Preservation of Favoured Races in the Struggle for Life. London: John Murray, 1859. 
[49] R. A. Fisher. The Genetical Theory Of Natural Selection. 1930.

[50] M. Mitchell. An Introduction to Genetic Algorithms. MA: The MIT Press, 1998.

[51] L. J. Fogel. Autonomous automata. Industrial Research Magazine, 4(2):14-19, 1962.

[52] T. Bäck, D. B. Fogel, and Z. Michalewicz. Evolutionary Computation 1: Basic Algorithms and Operators. 2000.

[53] K. Chellapilla. Combining mutation operators in evolutionary programming. IEEE Transactions on Evolutionary Computation, 2(3):91-96, 1998.

[54] A. S. Fraser. Simulation of genetic systems. Journal of Theoretical Biology, 2:329-346, 1962.

[55] A. S. Fraser. The evolution of purposive behavior. In Purposive Systems. WDC: Spartan Books, 1968.

[56] H. J. Bremermann. Part I: Limitations on data processing arising from quantum theory. In Self-Organizing Systems. M. C. Yovits and G. T. Jacobi and G. D. Goldstein, 1962.

[57] H. J. Bremermann, M. Rogson, and S. Salaff. Search by Evolution. In Biophysics and Cybernetic Systems. WDC: Spartan Books, 1965.

[58] J. H. Holland. Outline for a logical theory of adaptive systems. Journal of the Association for Computing Machinery, 9(3):297-314, 1962.

[59] J. H. Holland. Adaptive plans optimal for payoff-only environments. Proc. Of the 2nd Hawaii Int. Conf. On System Sciences, 917-920, 1969.

[60] J. H. Holland. Adaptation in Natural and Artificial Systems. Ann Arbor: Univ. Of Michigan Press, 1975.

[61] D. B. Fogel. Evolutionary Computation: Toward a New Philosophy of Machine Intelligence. The IEEE Press, 3a ed., 2006. 
[62] A. E. Elben and J. E. Smith. Introduction to Evolutionary Computation. Springer, 2003.

[63] L. B. Booker, D. E. Goldberg, and J. H. Holland. Classifier systems and genetic algorithms. Artificial Intelligence, 40:235-282, 1989.

[64] J. R. Koza. Genetic Programming: On the Programming of Computers by means of Natural Selection. 1992.

[65] J. Holland. Genetic algorithms. Scientific American, 1992.

[66] S. O. Rezende. Sistemas Inteligentes - Fundamentos e Aplicações. Barueri, SP: Manole, 2005.

[67] D. Floreano and C. Mattiussi. Bio-Inspired Artificial Intelligence: Theories, Methods, and Technologies. MA: The MIT Press, 2008.

[68] R. Linden. Algoritmos Genéticos - uma importante ferramenta da inteligência computacional. 2008.

[69] ReoCities. Algoritmos Genéticos (AGs), disponível em: http://www.reocities.com/igoryepes/visualizar2.htm. Acesso em 02/2013.

[70] Estéfane G. M. de Lacerda. Algoritmos genéticos com parâmetros contínuos. disponível em: http://www.dca.ufrn.br/ estefane/metaheuristicas/ag_continuo.pdf. Último acesso em 03/03/2013, Maio 2008.

[71] E. K. P. Chong and S. H. Zak. An introduction to optimization. 2a ed, New York: John Wiley \& Sons Inc, 2001.

[72] Turing Finance. textitFitness Landscape Analysis for Computational Finance, disponível em: http://www.turingfinance.com/fitness-landscape-analysis-for-computational-finance. Acesso em 09/2015.

[73] J. Tejada, G. G. Bosco, S. Morato, and A. C. Roque. Characterization of rat behavior in the elevated plus-maze using a directed graph. Journal of Neuroscience Methods, 184(2):251-255, 2009. 
[74] F. Cardenas, M. R. Lamprea, and S. Morato. Vibrissal sense is not the main sensory modality in rat exploratory behavior in the elevated plus-maze. Behavioural Brain Research, 122(2):169-174, 2001.

[75] D. Purves, G. J. Augustine, D. Fitzpatrick, W. C. Hall, A.-S. LaMAntia, J. O. McNamara, and S. M., editors. Neuroscience. 3rd edition. Sinauer Associates, Inc., third edition, 2004.

[76] E. Ferneda. Redes neurais e sua aplicação em sistemas de recuperação de informação. Cência da Informação, 35(1):25-30, 2006.

[77] S. R. Y Cajal. Nueva concepta de la histologia de los centros nervosos. Annals of Surgery, 18:122, 1893.

[78] G. Buzsáki and A. Kandel. Somadendritic backpropagation of action potentials in cortical pyramidal cells of the awake rat. Journal of Neurophysiology, 79(3):1587-1591, 1998.

[79] Michael Häusser and Bartlett Mel. Dendrites: bug or feature? Current Opinion in Neurobiology, 13:372, 2003.

[80] Balázs Rózsa, Gergely Katona, Kaszás, Attila, Szipöcs, Róbert, and E. Sylvester Vizi. Dendritic nicotinic receptors modulate backpropagating action potentials and long-term plasticity of interneurons. European Journal of Neuroscience, 27(2):364, 2008.

[81] W. Gerstner and W. Kistler. Spiking Neuron Models: Single Neurons, Populations, Plasticity. Cambridge University Press, 2002.

[82] X. Wang, Y. Zhao, X. Zhang, H. Badie, Y. Zhou, Y. Mu, L. S. Loo, L. Cai, R. C. Thompson, B. Yang, Y. Chen, P. F. Johnson, C. Wu, G. Bu, W. C. Mobley, D. Zhang, F. H. Gage, B. Ranscht, Y. Zhang, S. A. Lipton, W. Hong, H. $\mathrm{Xu}$. Loss of sorting nexin 27 contributes to excitatory synaptic dysfunction by modulating glutamate receptor recycling in Down's syndrome. Nature Medicine, 19:473-480, 2013. 
[83] J. Watson and F. Crick. Molecular structure of nucleic acids; a structure for deoxyribose nucleic acid. Nature, 171(4356):737-8, 1953.

[84] B. Alberts, A. Johnson, J. Lewis, M. R. Kazuo, K. Roberts, and P. Walters. Molecular Biology of the Cell. New York e London: Garland Science, 4a ed, 2022.

[85] Anthony J. F. Griffiths, William M. Gelbart, Jeffrey H. Miller, and Richard C. Lewontin. Modern Genetic Analysis. New York: W. H. Freeman, 1999. 


\section{Apêndice}

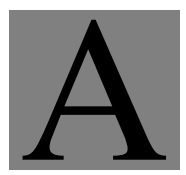

\section{Sistemas nervosos biológicos}

O neurônio é uma célula especializada, considerada a unidade básica do sistema nervoso. É a célula responsável pela condução de um sinal (impulso nervoso) para outros neurônios ou células. Um neurônio típico se divide em três partes: dendritos (também chamado de árvore dendrítica, devido a sua grande ramificação), soma (corpo celular) e axônio, como mostra a Figura A.1.

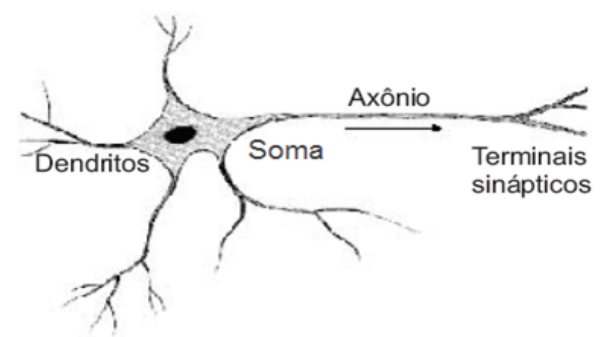

Figura A.1: Esquema ilustrativo que retrata um neurônio típico. Numa extremidade se encontra a árvore dendrítica, no centro está localizado o soma e na outra extremidade o axônio. Figura adaptada de [76].

Os dendritos são prolongamentos dos neurônios, especializados na recepção de estímulos nervosos que podem vir de outros neurônios ou do meio ambiente. O corpo celular é o local de maior volume na célula nervosa. É a zona estrutural do neurônio, onde são encontrados núcleo e citoplasma. O axônio é o principal responsável pela condução dos impulsos nervosos para outras células. Cada neurônio possui normalmente um único axônio, que, em geral, não se ramifica em abundância.

Impulsos são transmitidos entre uma célula nervosa e outra célula através de sinapses (palavra que vem do grego synapsis, que significa ação de juntar). Uma sinapse é uma região de contato muito próximo entre os neurônios, onde ocorre a 
maioria das comunicações interneuronais. Em uma sinapse as células estão muito próximas, sem, contudo, se tocarem. As terminações axonais e/ou dendríticas de um neurônio podem estabelecer várias sinapses simultaneamente.

A hipótese tradicional de que os impulsos elétricos são transmitidos unidirecionalmente do axônio de um neurônio (neurônio pré-sináptico, ou seja, neurônio emissor do sinal) ao dendrito de outro neurônio (neurônio pós-sináptico, receptor do sinal), suposta primeiramente por Ramon y Cajal [77], vem sendo complementada, ainda, por um grande número de pesquisas que têm mostrado que pode haver uma retropropagação dos sinais elétricos pelos dendritos, de modo que os dendritos possam atuar como elementos pré-sinápticos [78, 79, 80].

Existem vários tipos de sinapses no cérebro humano, que podem, porém, ser classificadas em duas classes gerais: sinapses elétricas e sinapses químicas. As sinapses elétricas estão presentes nos sistemas nervosos de todos os animais, entretanto têm sido bem menos estudadas do que as sinapses químicas, que constituem a principal forma de comunicação interneuronal nos cérebros de vertebrados [81]. Quando um potencial de ação (impulso elétrico) é disparado pelo neurônio pré-sináptico, algumas de suas vesículas são fundidas à membrana celular, liberando seus neurotransmissores na fenda sináptica por meio de exocitose. Os neurotransmissores liberados se ligam a receptores sinápticos específicos presentes na célula pós-sináptica, causando abertura (ou às vezes fechamento) dos canais iônicos desta célula. Assim a condutância e o potencial de membrana costumam ser alterados, aumentando ou diminuindo a probabilidade de que o neurônio pós-sináptico emita um potencial de ação (também chamado de spike) [75]. Se um número suficiente de sinapses - de um só neurônio pré-sináptico ou, mais comumente, de vários neurônios pré-sinápticos ao mesmo tempo - forem acionados e produzirem uma mudança grande o suficiente na voltagem da célula pós-sináptica (se atingir o limiar de disparo da célula), esta pode emitir um ou mais potenciais de ação, transmitindo o sinal adiante para outros neurônios. Ao mesmo tempo em que a transmissão sináptica se propaga pelo neurônio pós-sináptico, o neurônio pré-sináptico reconstrói suas vesículas e as preenche com novas moléculas de seu(s) neurotransmissor(es) específico(s) e também com moléculas recolhidas (recaptadas) da fenda sináptica. Dado que este processo não é instantâneo, podemos supor que 
a sinapse fica momentaneamente com sua eficácia diminuída.

Desta maneira se dá o funcionamento do cérebro: a partir da transmissão constante de sinais elétricos e químicos ao longo do corpo. Nossos pensamentos, nossas atitudes e nossas sensações dependem de quais neurônios estão mais ou menos ativos a cada instante. A Figura A.2 mostra uma rede de neurônios de ratos reais saudáveis.

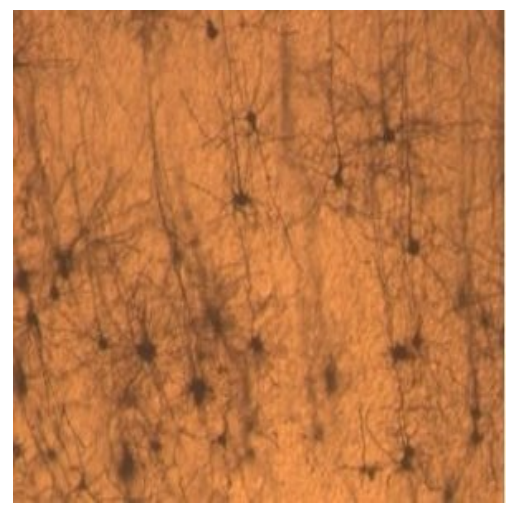

Figura A.2: Foto de uma rede neuronal típica de ratos reais saudáveis. Imagem adaptada de [82].

Nas redes neurais artificiais, os pesos das conexões neuronais são semelhantes, em termos biológicos, ao número de receptores presentes nas sinapses entre pares de neurônios. Dependendo desse peso sináptico, o neurônio artificial pode ser ativado e disparar um potencial de ação, que pode ser ou não propagado, resultando em uma saída calculada por uma função de ativação específica utilizada em cada modelo. 


\section{Apêndice}

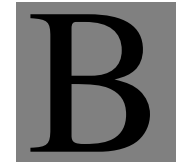

\section{A terminologia biológica no uso de algoritmos genéticos}

Os termos biológicos são usados nos AGs (assim como nas RNAs) como simples analogia, inspiração para modelagem, sendo os modelos computacionais muito mais simples do que os sistemas biológicos reais.

Os pilares da evolução natural são: população, diversidade, hereditariedade e seleção. A evolução representa a alteração nas características hereditárias da população de uma geração para outra ao longo do tempo. A hereditariedade corresponde à transmissão de características individuais dos pais para os filhos durante a reprodução. As diferenças hereditárias podem ser observadas tanto em indivíduos de espécies diferentes quanto em indivíduos de uma mesma espécie [67]. A seleção natural, proposta por Darwin, se baseia na premissa de que indivíduos mais bem adaptados ao ambiente são mais capazes de se reproduzir. Essa seleção de indivíduos não é feita aleatoriamente, portanto, mas, sim, de acordo com o grau de aptidão individual. Por exemplo, em um ambiente superpopuloso com escassez de comida, terão mais chances de sobreviver e poder se reproduzir aqueles indivíduos com maior habilidade e/ou rapidez em conseguir alimento. Então, podemos dizer que o nível de adaptação a essas tarefas influencia de forma direta a seleção dos indivíduos. Se alterações nesse ambiente ocorrerem, o indivíduo mais apto não será necessariamente o mesmo de outrora. Nesse sentido, dadas as constantes alterações ambientais, o significado do progresso é que cada indivíduo tenta ser melhor no futuro, mas não existe um objetivo final ou estado ótimo específico a ser atingido. A evolução natural não tem planos, objetivo nem fim [67]. 
A diversidade de indivíduos acontece, pois os filhos não são cópias idênticas dos pais. É chamado de fenótipo a característica ou o conjunto de características físicas, fisiológicas e comportamentais de um ser vivo. Essas características são determinadas pelo genótipo (constituição genética) do indivíduo em interação com o ambiente. O gene é um seguimento da molécula de ADN (ácido desoxirribonucleico) que contém uma instrução codificada para a síntese de uma proteína. Vale salientar que nem sempre uma característica hereditária é determinada por um único gene, podendo ser ocasionada por um conjunto de genes. Além disse, existem trechos do ADN que não codificam proteínas, mas têm importância estrutural ou estão envolvidos na regulação do uso da informação genética.

A estrutura da molécula de ADN foi descoberta conjuntamente pelo norte-americano James Watson e pelo britânico Francis Crick [83], em 1953, propiciando-lhes o Prêmio Nobel de Fisiologia ou Medicina em 1962, juntamente com Maurice Wilkins. Em organismos vivos, o ADN não existe como uma molécula única (cadeia simples), mas sim como um par de moléculas firmemente associadas. As duas longas cadeias (também chamadas de "fitas") de ADN enrolam-se formando uma dupla hélice. Cada fita de ADN é um longo polímero de unidades simples (monômeros) de nucleotídeos, cuja cadeia principal é formada por moléculas de açúcares (desoxirriboses) e fosfato intercalados unidos por ligações fosfodiéster. Ligada a cada molécula de desoxirribose está uma base nitrogenada. A sequência de bases ao longo da molécula de ADN constitui a informação genética. Esse conjunto composto por açúcar, fosfato e base nitrogenada corresponde a um nucleotídeo. São quatro os tipos de bases nitrogenadas presentes no ADN: adenina, guanina, citosina ou timina. A leitura destas sequências é feita através do código genético, que especifica qual aminoácido corresponde a cada tripla de bases nitrogenadas. Para isso, moléculas de ARN (ácido ribonucleico) mensageiro copiam parte da cadeia de ADN através de um processo chamado transcrição. Posteriormente essa informação é "traduzida" em proteínas pelo processo intitulado tradução [84].

O ADN, na maior parte dos seres vivos, fica no núcleo das células. O material genético de um indivíduo é organizado em moléculas de ADN separadas, chamadas de cromossomos. Em muitas espécies, os cromossomos existem em pares (fazendo com que esses organismos sejam conhecidos como diploides, diferentemente 
daqueles nos quais os cromossomos existem em unicidade - os haploides). Os dois cromossomos em um par homólogo correspondem a áreas que produzem proteínas com funcionalidade similar nas células. Os humanos, por exemplo, contêm 23 pares de cromossomos [67]. Cada local fixo num cromossomo onde está localizado determinado gene ou marcador genético é chamado de locus.

$\mathrm{Na}$ reprodução sexual de organismos diploides ocorre a recombinação (ou crossover), na qual, para cada pai, os genes de um par de cromossomos são trocados de modo a gerar um cromossomo único (gameta). Os gametas dos pais se unem para formar o cromossomo diploide do filho. Esse processo é chamado de meiose. Já na reprodução haploide, os genes das cadeias simples de cromossomos dos pais são trocados, originando um filho haploide. Os rearranjos cromossômicos dos pais resultantes nos filhos podem tornar certas combinações de genes mais adaptativas e mais fáceis de serem mantidas nas populações. Esse tipo de reprodução é chamada de mitose [50].

Além disso, durante a reprodução, os genes podem sofrer mutações - mudanças na sequência de seus nucleotídeos. Mutações podem ser causadas por erros de cópia do material durante a divisão celular, por exposição a radiação ultravioleta ou ionizante, mutagênicos químicos ou vírus. As mutações gênicas mais sérias são aquelas decorrentes de uma adição ou perda de uma base, alterando toda a sequência do ADN a partir do ponto em que ela ocorre. Geralmente estas mutações são letais [85]. Juntas, as recombinações e as mutações gênicas contribuem em grande parte para a variabilidade das espécies. 